\title{
Chronology of
}

\section{Emplacement of Mesozoic}

Batholithic Complexes

In California and

\section{Western Nevada}

By J. F. EVERNDEN and R. W. KISTLER

GEOLOGICAL SURVEY PROFESSIONAL PAPER 623

Prepared in cooperation with the

University of California (Berkeley)

Department of Geological Sciences

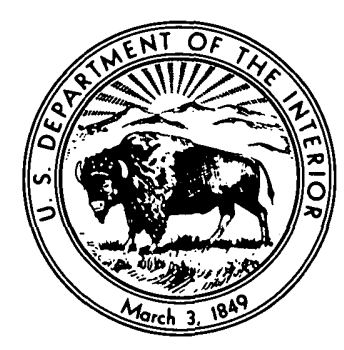

UNITED STATES GOVERNMENT PRINTING OFFICE, WASHINGTON : 1970 


\section{UNITED STATES DEPARTMENT OF THE INTERIOR}

WALTER J. HICKEL, Secretary

GEOLOGIGAL SURVEY

\section{William T. Pecora, Director}

Library of Congness catalog-card No. $78-603860$

For sale by the Superintendent of Documents, U.S. Government Printing Office Washington, D.C. 20402 - Price $\$ 1.25$ (paper cover) 


\section{CONTENTS}

Abstract_.

Introduction

Analytical problems.

Analytical procedures.

Precision and accuracy

Potassium determinations...

Argon determinations.

Chemical and crystallographic effects on potassium-argon ages

Apparent age as a function of chlorite content of biotite

Apparent age as a function of mineral type

Apparent potassium-argon ages of quartz from granitic rocks.

Geologic interpretation

Genctic significance of potassium-argon ages of biotite and hornblende

Potassium-argon age in plutons of Cathedral Peak type.....

Depth of cmplacement of the Sierran plutons

Discordant biotite-hornblende pairs-evidence of reheated plutons

Concordant biotite-hornblende pairs-evidence of the age of an intrusive event. . .

Growth of the Sierra Nevada batholith

Cathedral Range intrusive epoch of Late Cretaceous age

Huntington Lake intrusive epoch of Early Cretaceous age

Yosemite intrusive epoch of Late Jurassic age . .

Inyo Mountains intrusive epoch of Early and Middle Jurassic age

Lee Vining intrusive epoch of Middle and Late Triassic age

Summary of ages in all intrusive epochs

Uplift of plutons of the transverse and Coast Ranges.

Granitc cmplacement and sedimentation on the continent....

Correspondence of intrusive and deformational events in the Sierra Nevada.

Conclusions. . .

References cited

\section{ILLUSTRATIONS}

Pute 1. Map showing distribution of Mesozoic granitic rocks in California and western Nevada Page

2. Map showing potassium-argon age of biotite and (or) hornblende for each locality shown on plate 1...... In pocket

Fraure 1. Histograms of $\delta_{(x-y)}$ values

2. Sketch map showing potassium-argon dates on samples from plutons of Cathedral Peak type, Sonora and Cathedral Peak plutons.........

3. Sketch map showing potassium-argon dates on samples from plutons of Cathedral Peak type, Recess and Whitney plutons.......

4. Graph showing pressure-temperature fields for metamorphic mineral and rock pairs

5. Graphic representation of heat model for intrusive rocks of the Sierra Nevada

6. Rubidium-strontium isochron plots for granitic rocks in California

7. Diagram showing potassium-argon mineral ages and rubidium-strontium whole-rock ages for the Lec Vining, Yoscmite, Huntington Lake and Cathedral Range intrusive epochs . . . .

s. Diagram showing potassium-argon mincral ages and rubidium-strontium whole-rock ages for granitic rocks of the Inyo Mountains, Yosemite, Huntington Lake, and Cathedral Range intrusive epochs...............

9. Diagram showing relation of sedimentation in the Sacramento Valley to granite cmplacement in the Sierra Nevada area........

10. Curve showing extent of epicontinental seas and Mesozoic and Cenozoic time scale 


\section{TABLES}

TABLE 1. Potassium-argon ages of minerals with duplicate argon analyses

2. Data showing variation of potassium-argon age with variation in chlorite content in biotite

3. Multimineral analyses (of same rock)

4. Rubidium-strontium analytical data

5. Potassium-argon analyses and location of sample localities

6. Rock name and description of sample locality 


\title{
CHRONOLOGY OF EMPLACEMENT OF MESOZOIC BATHOLITHIC COMPLEXES IN CALIFORNIA AND WESTERN NEVADA
}

\author{
By J. F. Evernden ${ }^{1}$ and R. W. Kistuer
}

\begin{abstract}
$\mathrm{Ar}^{40} / \mathrm{K}^{40}$ was determined for minerals from specimens of Mesozoic granitic rocks collected at 250 localities in California and western Nevada. Analytical reproducibility of $\mathrm{Ar}^{40} / \mathrm{K}^{40}$ in common minerals from granitic rocks was tested in the laboratories of the U.S. Geological Survey and University of California (Berkeley), and the results were studied for interpretation of the genetic significance of potassium-argon ages derived from the ratios.

The potassium-argon ages of minerals from Mesozoic granitic rocks in California have a continuity from 210 to 80 million years ago. However, a distinct periodicity of magma generation and intrusion is shown when the ages are related to the distribution of 'genetic groups of plutons based on geologic mapping. Five epochs of magma generation and emplacement that took from 10 to 15 million years to complete were initiated at approximately 30-million year intervals. Each intrusive epoch was preceded by, or was in part contemporaneous with, a period of regional deformation in California or western Nevada. These intrusive epochs and their ages are :
\end{abstract}

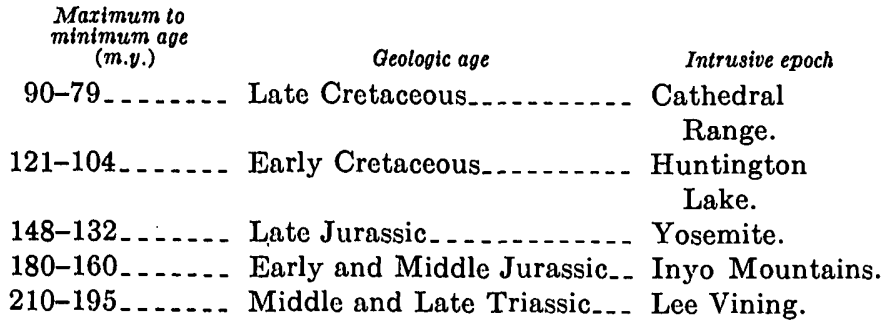

\section{INTRODUCTION}

The motivations for this study derive both from the desire to investigate and document further the influence of various factors on the precision and accuracy attainable in the measurement of potassium-argon ratios in minerals of granitic rocks and from an interest in the problem of genesis and emplacement of pluton complexes such as those of California and western Nevada. Study emphasis is on the well-exposed Sierra Nevada batholith in California.

It must be made clear that precision and accuracy as used here refer only to problems of potassium and argon measurement and not to the meaning of "apparent

1 Present afflintion, Advanced Research Projects Agency, Washington, D.C. ages." Accepting this as the only possible meaning to be signified by plus or minus estimates on determined "ages," there is very little documentation of factors influencing such plus or minus estimates. Moreover, highly variable statements are still made by different investigators with little or no supporting data. Some investigators report ages with "probable errors of about 5 percent," while others imply precision of 1 percent. The data of the present paper clearly show the influence of diverse factors on precision and accuracy of potassium-argon ages. The investigation of determined potassium-argon ratios as a function of mineral alteration or other factors has indicated the necessity of considering such factors in the interpretation of derived "ages."

Data previously presented (Evernden and Richards, 1962) on the Paleozoic batholiths of eastern Australia strongly suggested that there had been continuity of granite generation and emplacement over a period of some 200 million years. The locus of batholithic intrusion moved more than $300 \mathrm{~km}$, but the "ages" obtained implied the virtual lack of any cessation of emplacement of granitic magma during that long interval. On the other hand, previous interpretations of ages of granitic rocks from the Sierra Nevada of California have implied at least two distinct periods of granite emplacement (Curtis and others, 1958). Kistler, Bateman, and Brannock (1965) have suggested three possible age groups.

We show that the patterns of ages of granitic rocks in the Sierra Nevada, taken altogether, have a continuity similar to that of the ages of granitic rocks in eastern Australia. However, a distinct periodicity of magma generation and intrusion is shown when potassium-argon and rubidium-strontium ages are related to the distribution of genetic groups of plutons based on geologic mapping. We also show that the thermal history of individual plutons is reflected in their mineral ages and that, with a few assumptions, the data permit estimates of the crustal level of emplacement of the plutons.

An essential assumption in the discussion that follows 
is that the "ages" obtained by potassium-argon analysis result primarily from a more or less complex cooling history for each pluton and mineral. Virtually all investigators have concluded that the plutons of the Sierra Nevada are the product of magmatic emplacement. In fact, the pattern of ages obtained seems to be inconsistent with any other interpretation. Assuming this and assuming no later reheating of the rock, then at best the potassium-argon age of a mineral from the rock will be a determination of the time when this magma mass had cooled sufficiently to allow retention of argon in the crystal lattice. Because of pronounced difference in diffusion rate in relation to temperature for argon in biotite and hornblende (Hart, 1964), the amount of discordance between biotite and hornblende ages from rocks will be, in some sense, a measure of the cooling rate of the pluton. Thus, concordance of these two ages implies rapid cooling and a near approach of the determined age to the time of initiation of cooling of the pluton. On the other hand, reheating of the sample by later intrusion will result in partial or complete loss of previously generated argon and will often give rise to marked discordance in biotite and hornblende ages. If the pattern of discordance is accurately delineated, conclusions about the pattern of growth of the pluton complexes become possible.

Many of the samples collected for this study are from areas that are virtually unmapped in terms of delineation of individual plutons. This is unfortunate, but we point out that the great span of time, Late Triassic to Late Cretaceous, represented by the Mesozoic intrusive rocks of California, is demonstrated mainly by the data of geochronometry and not by stratigraphic correlation. In fact, even in areas of detailed mapping, the ages of intruded rocks are so poorly known, or stratigraphic columns have such large gaps, that geologic assignment of ages of intrusive rocks is usually possible only within the limits of two or more geologic periods. It was decided, therefore, that questions of sufficient interest for this study could be answered without further detailed field control, while such a pattern of dates as here demonstrated may act as a stimulus to field investigations.

Prior to the writing of the paper, we had been dating rocks independently in different areas of the Sierra Nevada and adjacent batholiths of California and western Nevada as part of work at the University of California (Berkeley) and the Geological Survey. In order to present as comprehensive a report as is possible at present and to facilitate the publication of the large mass of data gathered, we combined our efforts for this paper.

The discussions separate logically into two parts. The first part deals with analytical problems such as the precision and accuracy of potassium measurements (a similar treatment for argon measurements is to be found in Evernden and Curtis, 1965) and the influence of chemical and mineralogic factors on apparent potassium-argon ages. The second part is the geologic interpretation of the total body of the absolute age data. The two parts can be read as nearly separate papers.

\section{ANALYTICAL PROBLEMS}

\section{ANALYTICAL PROCEDURES}

Standard analytical techniques for potassium and argon used at the University of California (Berkeley) are described in Evernden and Curtis (1965); similar techniques used by the U.S. Geological Survey are described in Kistler and Dodge (1966). Precision and accuracy obtained for potassium-argon ages at UC Berkeley have been reported by Evernden, Savage, Curtis, and James (1964); those obtained by the Geological Survey by Kistler (1968).

The rubidium-strontium analyses of granitic rocks that are reported in this paper were made by Carl Hedge or by Kistler. Rubidium and strontium were determined by standard isotope dilution techniques and by $\mathrm{X}$-ray fluorescence analyses.

Localities of all analyzed specimens are shown on plate 1 and are tabulated in table 5 of this report. Potassium-argon ages of biotite and (or) hornblende are shown for each locality on plate 2. Potassium-argon analytical data are tabulated in table 5 and rubidiumstrontium analytical data are tabulated in table 4. Rock names and descriptions are given in table 6.

\section{PRECISION AND ACCURACY}

\section{POTASSIUM DETERMINATIONS}

All potassium analyses at UC Berkeley were made by means of a flame photometer with a propane flame. The galvanometer was replaced by oǹe having greater precision of movement. $\mathrm{NH}_{4} \mathrm{OH}$ and $\left(\mathrm{NH}_{4}\right)_{2} \mathrm{CO}_{3}$ are made in the laboratory; all other chemicals are reagent grade. All measurements are made against carefully buffered standards; all new determinations are made in duplicate; and with every set of four new determinations, a repeat of a previously analyzed specimen is performed. Blank runs now yield values between 0.013 and 0.018 ppm potassium in 200 -cc solution.

The problem to be approached first is that of reproducibility of results by the technique used. The first requirement of such an evaluation is the use of a concentrate of very high purity. As will be demonstrated below, this is not easily obtained. However, one such concentrate of leucite has been available in large quan- 
tity and 31 analyses on it were run during 33 months. The average potassium value was 15.793 percent with the standard deviation of a single determination equal to 0.020 , or the coefficient of variation of a single determination equal to 0.13 percent. These calculations were based upon normal distribution theory, but no single determination departed from the mean by more than 0.25 (twice the coefficient of variation). Another sample, NBS 99, was run 21 times during the same period of time with a mean potassium value of 0.331 percent; the standard deviation of a single determination was 0.002 percent, and the coefficient of variation was 0.6 percent (samples dried at $105^{\circ} \mathrm{C}$ for 24 hours). Neither of these series showed an observable drift of determined potassium value with time, although the standard solutions have been stored in polyethylene bottles with screw tops. Other shorter series also support the conclusion that, on materials of high purity or uniformity containing several percent potassium, the coefficient of variation of a laboratory's precision should be a small fraction of 1 percent, and at the 90 -percent confidence level, below 1 percent.

To achieve as high purity in the biotite concentrates as was consistent with reasonable expense, samples were handpicked under a binocular microscope in the size ranges 10/16 and 16/28 Tyler mesh (exceptions to these size ranges are noted in table 5). All samples.were run in duplicate. For statistical purposes, if all biotite samples were considered equal in regard to variability within the concentrates, then all samples should have the same coefficient of variation. We can treat the data as two independent sets of determinations, Set 1 $(x)$ being the first value for each of the 141 samples, and Set $2(y)$ the second value. The complete independence of Set 1 and Set 2 allows us to write

$$
\sigma_{(x-y)}^{\prime 2}=\sigma_{x}^{\prime 2}+\sigma_{y}^{\prime 2}=2 \sigma_{x}^{\prime 2}
$$

Observed values of $(x-y)$ yield $\sigma_{(x-y)}^{\prime 2}=0.1752$ percent or $\sigma_{x}^{\prime}=0.296$ percent and $\sigma_{(x+y) / 2}^{\prime}=0.210$ percent (all $\sigma^{\prime}$ values being coefficients of variation).

Thus the coefficient of variation of the mean of the two determined values is, according to normal distribution theory as applied to all of the data, two-tenths of 1 percent, and the coefficient of variation of a single determination is 0.3 percent. Two points should be noted: the $\sigma_{x}{ }^{\prime}$ value is higher than would be expected from a consideration of the leucite data, and the $(x-y)$ values do not show a normal distribution (fig. 1). These facts suggest that the pattern of figure 1 is not controlled solely by laboratory reproducibility but that additional factors are influencing the distribution. Chlorite content of the biotite grains seems to be the explanation. We have previously noted that it is impossible to obtain uniform splits of nonuniform samples. Many of the samples concentrated are from rock which, in thin section, appeared practically useless because of extensive chloritization. However, by crushing a few pounds of rock and by carefully picking grains which displayed no obvious chlorite content under reflected light, samples with potassium values above 7 percent were obtained in most cases. Biotite

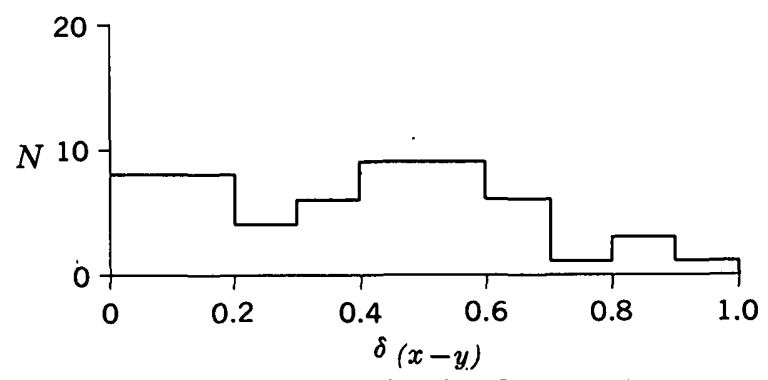

Picked Hornblende (57 samples)

(2 at 1.0-1.5)

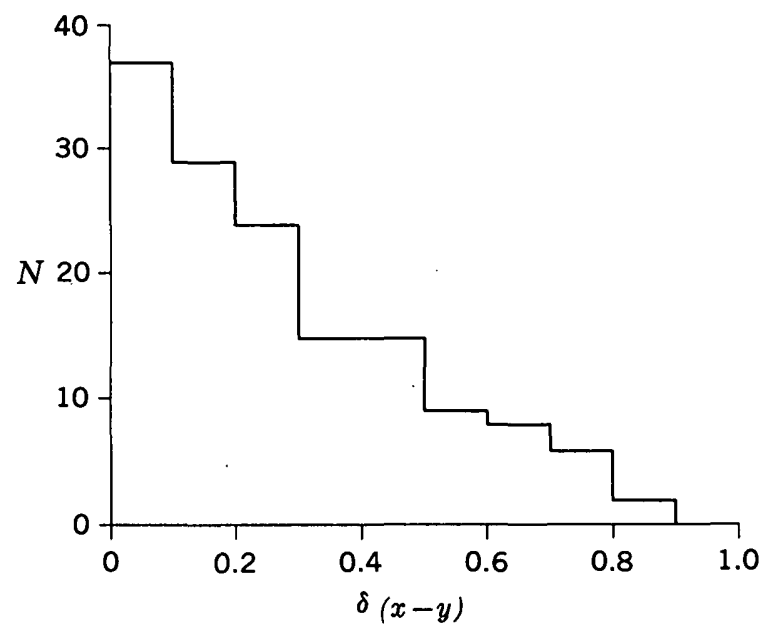

Picked Biotite (140 samples)

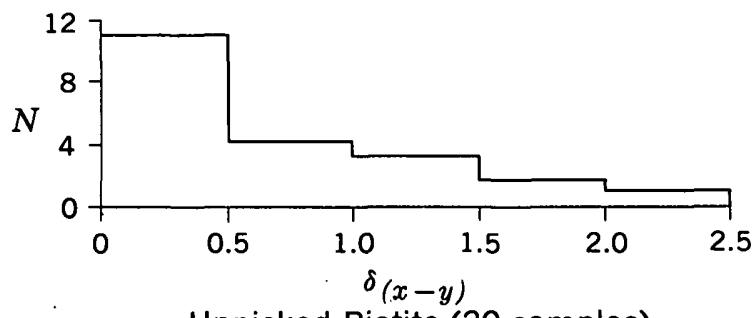

Unpicked Biotite (20 samples)

FraURe 1.-Histograms of $\delta_{(x-y)}$ values. $N$ is number of samples. 
books from such rocks often contain appreciable chlorite detectable only by further disaggregation of the books. Three lines of evidence suggest that this chlorite content is the explanation of the high $\sigma^{\prime}$ computed. Firstly, the observed $(x-y)$ values are a function of potassium content of the biotite; the mean of all samples with $\delta_{(x-y)}$ less than 0.1 percent is 7.6 percent potassium, whereas the mean of all samples with $\delta_{(x-y)}$ greater than 0.5 percent is 7.3 percent potassium $\left(\delta_{(x-y)}\right.$ being $(x-y)$ expressed as percent of the potassium value). Secondly, the $\delta_{(x-y)}$ values are a function of the sample and are not randomly distributed throughout the set of determinations. The evidence for this was obtained by repeated potassium analyses. Four samples with $\delta_{(x-y)}$ less than 0.1 percent and four with $\delta_{(x-y)}$ greater than 0.5 percent were rerun in duplicate; the second $\delta_{(x-y)}$ values are here termed $\delta_{(x-y)}{ }^{n}$.

\begin{tabular}{|c|c|c|}
\hline & $\begin{array}{c}\delta(x-v) \\
(\text { percent })\end{array}$ & $\begin{array}{c}\delta(x-y)_{n} \\
\text { (percent) }\end{array}$ \\
\hline KA 1540 & 0.03 & 0.1 \\
\hline 1568 & .05 & .09 \\
\hline 1573 & .1 & .01 \\
\hline $1575 \ldots$ & .04 & .09 \\
\hline $1525 \ldots-1-1,-1$ & .7 & .6 \\
\hline $1537 \ldots$ & .8 & .5 \\
\hline $1591 \ldots$ & .8 & .8 \\
\hline 1593 & .9 & .6 \\
\hline
\end{tabular}

Thirdly, several samples with $\delta_{(x-y)}$ values below 0.1 percent and above 0.5 percent were crushed and examined under the petrographic microscope. Invariably, those with high values of $\delta_{(x-y)}$ showed appreciable chlorite, whereas those with low values of $\delta_{(x-y)}$ showed little or no chlorite. A further demonstration of this correlation of high $\delta_{(x-y)}$ values with low potassium content and thus with appreciable chlorite and resulting inhomogeneity of sample is obtainable by comparing the potassium and $\delta_{(x-y)}$ values of picked and unpicked ( $\mathrm{P}$ and $\mathrm{U})$ samples in table 5 (all $\delta_{(x-y)}$ values are there rounded to the closest tenth percent) and by inspection of figure 1. It appears that the correlation of $\delta_{(x-y)}$ values and chlorite content is established and that such chlorite content degrades the precision or accuracy obtainable. We suggest, therefore, that all reported potassiumargon ages should include as an essential piece of information the $\delta_{(x-y)}$ values for each age determination, assuming that duplicate potassium analyses are performed. Note that virtually all the hornblendes have $\delta_{(x-y)}$ values of several tenths of 1 percent or higher (fig. 1), indicating a lower precision and accuracy for these "ages" than for the biotite ages.

Interlaboratory comparisons based upon samples showing high values of $\delta_{(x-y)}$ are pointless because it becomes difficult or impossible to separate laboratory differences from sample variation.
The main geologic conclusions of this paper will be based upon a study of the relative ages of both biotite and hornblende obtained for the numerous samples. As all the biotites and hornblendes are similar chemically there is no reason to expect that the results of flamephotometry procedures have significant errors in relative values greater than those of the analytical precision discussed above. Errors in analysis by flame photometry are of a systematic character, not random. Crosschecks against other laboratories and against results from different analytical techniques yield estimates of the accuracy of the determined potassium values, and thus of the accuracy obtainable with the procedures used. The following data have been recently obtained in a continuing effort to evaluate accuracy :

1. UC Berkeley values (Evernden and Curtis, 1965) on biotite $B$ 3203, 7.54, 7.57, 7.58, and 7.56 percent $K$, which are in good agreement with other published values (for example, see Hart, 1964, who reports a $\mathrm{K}$ value of 7.56 percent).

2. Results on samples run at both the University of California (Berkeley) and the Geological Survey by flame photometer but using different preparation procedures, and results of Survey analysis of actinolite and aegerine augite by atomic absorption (see unnumbered table).

Flame photometer results on samples run at both University of California (Berkeley) and the U.S. Geological Survey

\begin{tabular}{|c|c|c|c|c|}
\hline Sample & $\begin{array}{l}\text { Atomic } \\
\text { absorp- } \\
\text { tion } \\
\text { (percent) }\end{array}$ & $\begin{array}{l}\text { K (USGS) F } \\
\text { tometer (pes } \\
\text { values represe } \\
\text { of two detern }\end{array}$ & $\begin{array}{l}\text { lame pho- } \\
\text { ccent; all } \\
\text { nt average } \\
\text { ninations) }\end{array}$ & $\underset{\text { photometer (percent) }}{\text { K (UC Berkeley) Flame }}$ \\
\hline $\begin{array}{l}\text { B } 53-15 \mathrm{~A} \\
\text { (actinolite). }\end{array}$ & 0.060 & 0.060 & 0.0626 & $\begin{array}{l}(0.0639,0.0634, \\
0.0609,0.0621)\end{array}$ \\
\hline $\begin{array}{l}\text { FD-13 (plagi- } \\
\text { oclase) }\end{array}$ & & .267 & .272 & $(0.271,0.272)$ \\
\hline $\begin{array}{l}\text { CL-1 (plagio- } \\
\text { clase) }\end{array}$ & & .329 & .324 & $(0.3205,0.3279)$ \\
\hline $\begin{array}{l}\text { 422-H (aeger- } \\
\text { ine augite) }\end{array}$ & 0.54 & .054 & 0.54 & $\begin{array}{c}(0.0534,0.0546, \\
0.0536,0.0543)\end{array}$ \\
\hline $\begin{array}{l}\text { KA 1508-B } \\
\quad \text { (biotite) } \\
\text { KA 1566-B }\end{array}$ & & 7. 51 & 7.55 & $(7.53,7.57)$ \\
\hline $\begin{array}{l}\text { (biotite) --- } \\
\text { FD-13 (bio- }\end{array}$ & & 7. 36 & 7.55 & $(7.53,7.57)$ \\
\hline tite) & $\ldots$ & 7.75 & 7.86 & $(7.85,7.86)$ \\
\hline
\end{tabular}

3. Feldspars analyzed at UC Berkeley by two techniques: flame photometry (by J. Hampel) and $\mathrm{X}$-ray fluorescence (by R. Jack) ; results are tabulated and shown in percent (see unnumbered table). A comparison of columns 5 and 6 of the table suggests a correlation, as the mean $\epsilon^{\prime}$ for 
$\delta_{(x-y)}$ less than 0.5 is 0.32 , whereas the mean $\epsilon^{\prime}$ for $\delta_{(x-y)}$ equal to or greater than 0.5 is 1.27 . This agrees with the conclusion drawn from the biotite data; that is, large $\delta_{(x-y)}$ values are associated with nonuniform samples.

Feldspar analyses made by University of California (Berkeley)

\begin{tabular}{|c|c|c|c|c|c|c|c|}
\hline & mplo & $\begin{array}{c}1 \\
K(F / P)\end{array}$ & $\begin{array}{c}2 \\
K(X / R)[Q-1]\end{array}$ & ${ }^{3}$ & $\begin{array}{c}4 \\
K(X / R)[A D J]\end{array}$ & $\begin{array}{l}5 \\
\epsilon^{\prime}\end{array}$ & $\stackrel{6}{\delta(z-y)}$ \\
\hline \multirow[t]{14}{*}{ KA } & 1040 & 2. 562 & 2. 546 & 0.62 & 2. 558 & 0.15 & 0.2 \\
\hline & 1044 & 2. 569 & 2. 554 & .58 & 2. 566 & .10 & .2 \\
\hline & 1053 & 3. 237 & 3. 225 & .37 & 3. 243 & -.18 & .4 \\
\hline & 1041 & 3. 245 & 3. 266 & -.34 & 3. 274 & -.89 & .6 \\
\hline & 1029 & 3. 949 & 3. 893 & 1. 42 & 3. 917 & .82 & .6 \\
\hline & 1051 . & 4. 203 & 4. 164 & .93 & 4. 190 & .32 & .8 \\
\hline & 1017 & 4. 724 & $\begin{array}{l}4.630 \\
4.646\end{array}$ & 1. 82 & 4. 669 & 1. 16 & .6 \\
\hline & 1090 & 4. 962 & 5. 048 & -1.73 & 5. 081 & -2.40 & $: 6$ \\
\hline & 1178 & 5. 253 & 5. 250 & .06 & 5. 286 & .63 & .2 \\
\hline & 1089 & 5. 290 & 5. 249 & .78 & 5. 286 & .08 & .2 \\
\hline & 1054 & 5. 307 & 5. 363 & -1.06 & 5. 400 & -1.76 & .7 \\
\hline & 1193 & 5. 390 & 5. 391 & .02 & 5. 354 & .67 & .4 \\
\hline & 1365 & 5. 798 & 5. 731 & 1. 16 & 5. 774 & .42 & .2 \\
\hline & G-1. & 4. 600 & "4. 499" & 2.2 & 4. 529 & 1.55 & .5 \\
\hline
\end{tabular}

1. Potassium valuos obtained by flame photometry.

Potasslum values obtained by $X$-ray fluorescence, assuming a $\mathrm{K}$ value of 4.499 percont for $Q-1$.

4. Potassium $1-$ Volumn 2) $\times 100 /$ Column 1 . by plot of Column 1 versus Column 2 and adjustment indicated.

. (Column 1 - Column 4) $\times 100 /$ Column 1.

. Difforonco betweon the two $K$ values obtained by flame photometry, expressed as porcent of $\mathbf{K}$ value.

4. Potassium analyses repeated after 6 years on unpicked biotite samples. New runs have numbers ending in $(-64)$ :

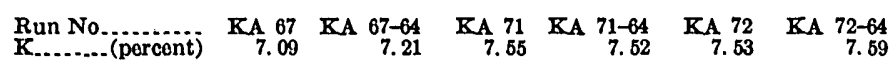

Both runs were performed on flame photometers, but by somewhat different preparation procedures.

\section{ARGON DETERMINATIONS}

Argon an'alyses are not routinely repeated. Control on argon precision and accuracy is obtained by repeats on several selected samples and by doing large numbers of genetically or temporally related samples. Thus, when dating volcanic rocks related to strata that yielded vertebrate fossils, the accuracy of the dates and other conclusions of the investigation were substantiated by a large body of age determinations related to many sites (Evernden and others, 1964). In the present investigation, several biotite samples were run in duplicate; in other words, splits of the same mineral concentrate were used in two independent argon analyses. All samples with numbers between KA 1432 and KA 1713 were analyzed by using spikes from a single spike set; this procedure eliminates any possible relative difference of age due to failure to intercalibrate different spike sets accurately. The data on repeat runs are given in table 1 (all runs are on picked samples). The mean difference of the picked biotite paired runs is 0.68 percent of the age. If the anomalously high value of KA 1608 is excluded, the mean difference is 0.48 percent. We can only suggest misweighing or undetected blow-out as possible causes of the discrepancy of the KA 1608 pair.

$\mathrm{T}_{\mathrm{ABLE}}$ 1.-Potassium-argon ages of minerals with duplicate argon analyses

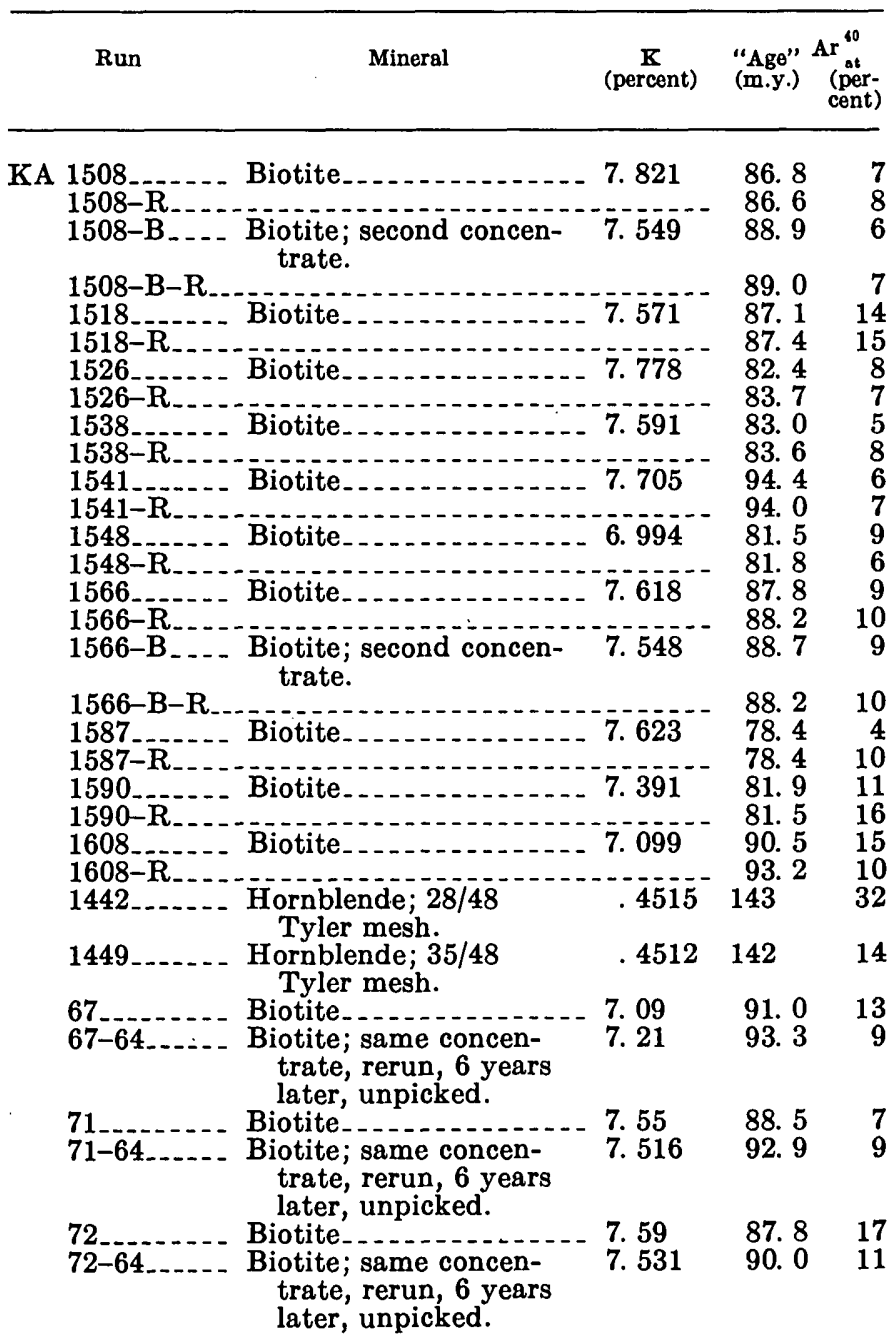

By duplicate analysis of argon from biotite, sanidine, and plagioclase from four USGS samples, the mean difference of paired runs is 1.3 percent of the age (Kistler, 1968).

A cross check between UC Berkeley and the Geological Survey served to intercalibrate the data from the two laboratories:

FD-13 Biotite.......... UC Berkeley ...... 124.9 $\times 10^{-11}$ moles/gram Ar $_{\text {Rad }}^{10}$ USGS........... 126.0 $10^{-11}$ moles/gram $\mathrm{Ar}_{\mathrm{Rad}}^{\mathrm{k0}}$ 
The UC Berkeley value represents a single determination, the USGS value the average of two analyses $(125.3,126.8)$.

\section{CHEMICAL AND CRYSTALLOGRAPHIC EFFECTS ON POTASSIUM-ARGON AGES}

\section{APPARENT AGE AS A FUNCTION OF CHLORITE CONTENT OF BIOTITE}

The discussion so far has been concerned solely with the reproducibility of potassium and argon analyses of given mineral concentrates. A matter of real concern is the effect of grain size and (or) chemical composition on the apparent age of a mineral concentrate. (See the following section, "Apparent age as a function of mineral type," for discussion of comparisons of apparent ages obtained from different minerals of the same rock sample, specifically for the minerals biotite, hornblende, potassium feldspar, plagioclase, and quartz.) The influence of chlorite content on age was investigated by analysis of two biotite-samples, one only slightly chloritized (KA 1511), the other extensively chloritized (KA 1527). The results are shown in table 2.

TABLE 2.-Data showing variation of potassium-argon age with variation in chlorite content in biotite

\begin{tabular}{|c|c|c|c|c|}
\hline $\begin{array}{l}\text { Picked (P) } \\
\text { or unpicked } \\
\text { (U) }\end{array}$ & Size (Tyler) & $\underset{\text { (percent) }}{\mathbf{K}}$ & $\begin{array}{c}\text { Age } \\
\text { (m.y.) }\end{array}$ & $\begin{array}{c}(x-y) \\
\text { (per- } \\
\text { cent) }\end{array}$ \\
\hline \multicolumn{5}{|c|}{ Few percent chlorite content in biotite books } \\
\hline 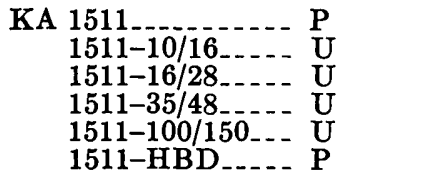 & $\begin{array}{c}16 / 28 \\
10 / 16 \\
16 / 28 \\
35 / 48 \\
100 / 150 \\
35 / 60\end{array}$ & $\begin{array}{l}\text { 7. } 438 \\
\text { 6. } 699 \\
\text { 6. } 176 \\
\text { 6. } 799 \\
\text { 7. } 093 \\
.876\end{array}$ & $\begin{array}{r}97.2 \\
97.5 \\
98.5 \\
101.4 \\
100.9 \\
124.6\end{array}$ & $\begin{array}{l}0.1 \\
.7 \\
.1 \\
.7 \\
.1 \\
.5\end{array}$ \\
\hline \multicolumn{5}{|c|}{ Very high chlorite content in blotite } \\
\hline 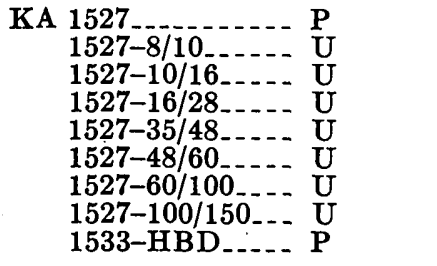 & $\begin{array}{c}10 / 16 \\
8 / 10 \\
10 / 16 \\
16 / 28 \\
35 / 48 \\
48 / 60 \\
60 / 100 \\
100 / 150 \\
28 / 60\end{array}$ & $\begin{array}{l}\text { 7. } 602 \\
\text { 7. } 315 \\
\text { 7. } 166 \\
\text { 6. } 880 \\
\text { 4. } 344 \\
\text { 3. } 171 \\
\text { 2. } 825 \\
\text { 1. } 630 \\
.670\end{array}$ & $\begin{array}{l}81.9 \\
80.2 \\
80.0 \\
82.0 \\
85.7 \\
86.9 \\
84.7 \\
90.8 \\
84.3\end{array}$ & $\begin{array}{r}0.0 \\
.8 \\
.4 \\
.3 \\
.1 \\
1.5 \\
.1 \\
.6 \\
.0\end{array}$ \\
\hline
\end{tabular}

Unpicked means that the biotite-chlorite concentrate was obtained by sizing and by using heavy liquids and that all other easily identified grains were removed by picking, care being taken not to alter the biotite-chlorite in the concentrate. Therefore, the slight increase of apparent age with decreasing grain size in KA 1511 cannot with certainty be separated from the possible presence of hornblende, although a 13 percent hornblende content would be required to explain the indicated increase in age in KA 1511-100/150. Note that the hornblende in this rock (table 2, KA 1511-HBD) is older than the biotite. The selection of this biotite for size analysis was made on the basis of its low content of chlorite prior to discovering the discordant biotitehornblende ages. These data are still in marked contrast to those from KA 1527. In the KA 1527 series, the concentration of chlorite in the small grain sizes is clearly shown by the four- to five-fold decrease in potassium content with decreasing grain size. The apparent ages, though not rising in a perfectly systematic manner, increase by over 10 percent with the decrease of potassium. Run KA $1533-\mathrm{HBD}$, done on a hornblende sample taken from the same end of the same pluton as KA 1527 (Cathedral Peak pluton, see fig. 2), indicates that the increase in apparent age in the $\mathbf{K A}$ 1527 series cannot be attributed to the included hornblende. Numerous samples from the south end of the Cathedral Peak pluton (fig. 2) have been analyzed with the apparent ages showing a seeming correlation with potassium content (all samples picked) :

\begin{tabular}{|c|c|c|c|c|}
\hline Run & $\begin{array}{l}\text { Size } \\
\text { ("Tyler } \\
\text { mesh) }\end{array}$ & $\underset{\text { (percent) }}{\mathbf{K}}$ & $\underset{(\mathrm{m} \cdot \mathrm{y} .}{\mathrm{Age}})$ & $\begin{array}{c}\text { Elevation } \\
\text { (ft) }\end{array}$ \\
\hline 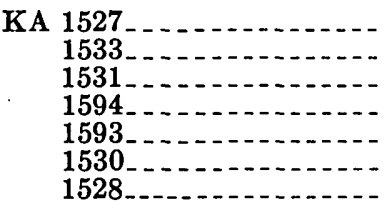 & $\begin{array}{l}10 / 16 \\
16 / 28 \\
16 / 28 \\
16 / 28 \\
16 / 28 \\
10 / 16 \\
16 / 28\end{array}$ & $\begin{array}{l}\text { 7. } 602 \\
\text { 7. } 545 \\
\text { 7. } 443 \\
\text { 7. } 120 \\
\text { 7. } 100 \\
\text { 7. } 053 \\
\text { 6. } 845\end{array}$ & $\begin{array}{l}\text { 81. } 9 \\
82.5 \\
83.6 \\
82.4 \\
83.4 \\
83.7 \\
84.6\end{array}$ & $\begin{array}{r}8,800 \\
8,800 \\
9,000 \\
8,700 \\
10,900 \\
9,000 \\
8,800\end{array}$ \\
\hline
\end{tabular}

Five samples from the north end of the same pluton show the following relationship:

\begin{tabular}{|c|c|c|c|c|c|}
\hline & Run & $\begin{array}{c}\text { Size } \\
\text { (Tyler } \\
\text { mesh) }\end{array}$ & $\underset{\text { (percent) }}{\mathbf{K}}$ & $\underset{\text { (m.y.) }}{\text { Age }}$ & $\begin{array}{c}\text { Elevation } \\
\text { (ft) }\end{array}$ \\
\hline $\mathbf{K A}$ & $\begin{array}{l}1598 \\
1597 \\
1595 \\
1599 \\
1596\end{array}$ & $\begin{array}{l}16 / 28 \\
16 / 28 \\
16 / 28 \\
16 / 28 \\
28 / 48\end{array}$ & $\begin{array}{l}\text { 7. } 598 \\
\text { 7. } 435 \\
\text { 7. } 296 \\
\text { 7. } 208 \\
\text { 6. } 979\end{array}$ & $\begin{array}{l}80.1 \\
80.2 \\
81.0 \\
81.4 \\
81.4\end{array}$ & $\begin{array}{r}7,300 \\
7,950 \\
11,000 \\
9,000 \\
9,200\end{array}$ \\
\hline
\end{tabular}

The set from the north end may not be significant, but the set from the south end is certainly significant in light of the initial discussion of reproducibility of potassium and argon values. The suite of samples from the southern end of the pluton shows a strong correlation of potassium content and apparent age, as does the sequence of sized samples of KA 1527, a member of the suite. The explanation is not at all obvious. As a matter of fact, the correlation is exactly opposite to that expected. Much of the chloritization in these rocks is a weathering phenomenon rather than the result of deuteric processes. Furthermore, it would seem quite impossible to explain the above data in terms of chlorite development at time of emplacement. The only possible 
explanation must be in terms of a weathering process which achieved more complete removal of potassium than argon during chloritization. This conclusion, in turn, would seem consistent only with many of the argon atoms being in nonpotassium (octahedral layer?) lattice sites, that is, sites less subject to destruction during chloritization. Thus, we may have obtained definitive evidence that many argon atoms are impelled into nonpotassium lattice sites by recoil at time of disintegration of the potassium and associated gamma-ray radiation. Whatever the explanation, the obvious conclusion is that an inverse correlation of apparent age and potassium content in biotites can occur. Previously published results (Evernden and others, 1964, p. 160) are not in disagreement with this conclusion, as the potassium values for the series reported there changed by only 30 percent.

\section{APPARENT AGE AS A FUNCTION OF MINERAI TYPE}

In our haste to find answers to the more exotic problems of geochronology, many of the important details of argon distribution and retention in various minerals were not carefully investigated and are only slowly being supplied. Thus, the early rejection of all feldspars for potassium-argon analysis has been shown to have been too wide-ranging in scope. Virtually all volcanic feldspars seem to be satisfactory for potassium-argon dating throughout the Phanerozoic (Evernden and James, 1964). After the data were studied and this conclusion reached, it was not understandable why all feldspars of granitic rocks should be poor argon traps. Inspection of thin sections, however, shows that extensive alteration of both potassium-feldspar and plagioclase is virtually universal in the granitic rocks of the Sierra Nevada, and these minerals would be expected to be sources of poor potassium-argon dates. It appeared possible that use of altered or exsolved feldspars led to the early conclusions. Six relatively unaltered rocks were selected for complete analysis (table 3 ).

All feldspar concentrates were leached in hydrofluoric acid (Evernden and Curtis, 1965), sonically cleaned, and resized.

Four of the potassium-feldspar samples show either no microcline or only its incipient development, the potassium-argon ages of these samples being essentially concordant with the biotite ages on the same rocks (KA 1512, 1564, 1569, and 1605). Another potassiumargon age for untwinned potassium-feldspar from a Sierran granitic rock concordant with that for biotite and hormblende from the same specimen is reported in Kistler and Dodge (1966). The two potassium-feldspar samples which yielded ages in marked discordance with the biotite ages from the same rocks (KA 1533 and 1541) are extensively or completely converted to microcline.

The correlation of observed plagioclase characteristics with apparent age is not so obvious, but the six dates suggest the correlation of high argon retentivity with coarse to intermediate twinning thickness, and the correlation of low argon retentivity with alteration, thin twinning, and obvious strain. Since myrmekite is always a peripheral development, it may be that leaching with HF and sonic cleaning tend to remove such material from our concentrates, thus preventing the expected correlation of myrmekite development and deficient apparent ages.

The sample used is small, but it strongly suggests that a correlation exists between demonstrable crystal characteristics and apparent potassium-argon ages in the feldspars of instrusive rocks, a to-be-expected but as yet unsubstantiated result. The basic requirement seems to be an unrecrystallized homogeneous crystal phase with dimensions of at least several microns, that is, exactly what the study of argon retention in volcanic feldspars had indicated (Evernden and James, 1964).

\section{APPARENT POTASSIUM-ARGON AGES OF QUARTZ FROM GRANITIC ROCKS}

As first noted by Hart (1964), and as subsequently found by several investigators, it is possible to have excess quantities of argon in some pyroxenes of rocks of deep-seated origin. Exactly what "deep-seated" means in this connection is uncertain. Investigations of pyroxenes, sanidines, and plagioclases (oligoclase to bytownite) of extrusive volcanic rocks have found no argon excess. Where do granitic intrusive rocks lie in this proposed hierarchy of depth; that is, will the low-potassium minerals of granitic rocks show an argon excess? Analyzed pyroxenes of granite samples from the Sierra Nevada show the absence of excess argon (Kistler and Dodge, 1966). The sole remaining mineral present in appreciable quantity is quartz. The very low potassium content, its very late crystallization, and the possibility of gaseous inclusions within it would suggest that, if excess argon is to be found in granitic rocks, it will be found in quartz. Five quartz samples from Sierran granitic rocks have been analyzed.

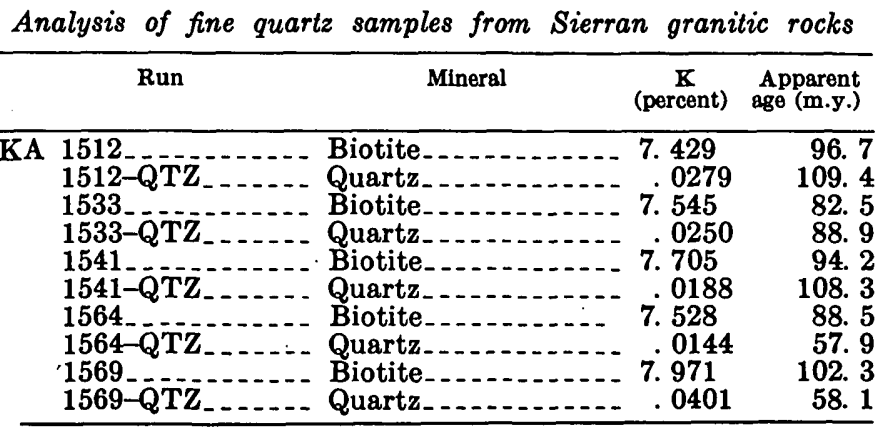


The potassium values were obtained by flame-photometry analysis, the only technique immediately available, and it is felt that the values computed are adequate for investigating the presence of excess argon in these samples.

Sample preparation was by crushing, sizing, and heavy liquids, followed by a very strong HF leach; the intent of this leaching was to destroy all plagioclase or to so grossly alter it that it could be easily separated from the quartz by picking. The picked concentrate was again leached in $\mathrm{HF}$ and sonically cleaned. The quartz was fused in our standard argon-extraction lines according to the procedure outlined previously for use with very young samples (Evernden and Curtis, 1965). Pyrex bottles with vicor liners were cooled by a strong stream of air. The residue was a somewhat vesicular mass in the bottom of the molybdenum crucible, approximately half of the quartz having been vaporized and thus re-

TABLE 3-Multimineral analyses (of same rock)

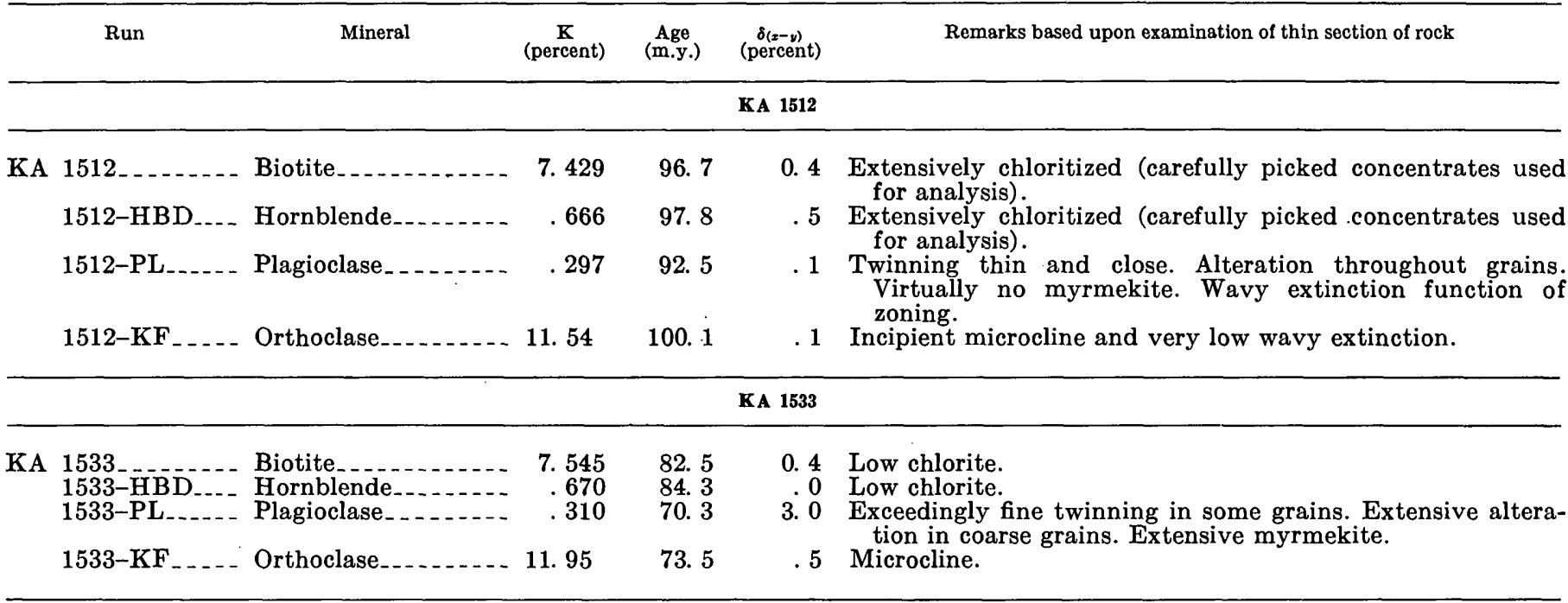

\section{KA 1541}

\begin{tabular}{|c|c|c|}
\hline KA $\begin{aligned} 1541 & \\
& 1541-\mathrm{HBD} \\
& 1541-\mathrm{PL}\end{aligned}$ & $\begin{array}{l}\text { Biotite } \\
\text { Hornblende } \\
\text { Plagioclase }\end{array}$ & $\begin{array}{r}7.705 \\
.736 \\
.233\end{array}$ \\
\hline $1541-\mathrm{KF}$ & Orthoclase. & 12. 25 \\
\hline
\end{tabular}
94. $4 \quad 0.7$ Very low chlorite.
97. $8 \quad .9$ Very low chlorite.
90. $7 \quad .1$ Much myrmekite. Pronounced wavy extinction. Coarse twinning. Zoned. Less altered than KA 1533-PL.
83. $5 \quad .5$ Extensive microcline twinning. Pronounced wavy extinction.

\begin{tabular}{|c|c|c|c|c|c|}
\hline \multicolumn{6}{|c|}{ KA 1564} \\
\hline KA & $\begin{array}{l}\text { 1564 } \\
1564-\mathrm{HBD}_{-}-\text {Biotite } \\
\text { 1564-PL }\end{array}$ & $\begin{array}{r}\text { 7. } 528 \\
1.070 \\
.277\end{array}$ & $\begin{array}{l}88.5 \\
95.6 \\
72.6\end{array}$ & $\begin{array}{r}0.2 \\
.9 \\
.8\end{array}$ & $\begin{array}{l}\text { Very low chlorite. } \\
\text { Very low chlorite. } \\
\text { Strong zoning. Myrmekite present but thin. Minimal wavy } \\
\text { extinction. En echelon shear in plagioclase grains. Some } \\
\text { distortion evident. } \\
\text { Essentially no microclinization. Minimum wavy extinction. }\end{array}$ \\
\hline \multicolumn{6}{|c|}{ KA 1569} \\
\hline KA & $\begin{array}{l}1569 \\
1569-\mathrm{HBD}_{1} \\
1569-\mathrm{PL}\end{array}$ & $\begin{array}{l}7.971 \\
.590 \\
.774\end{array}$ & $\begin{array}{l}\text { 102. } 3 \\
107.5 \\
102.4\end{array}$ & $\begin{array}{r}0.1 \\
2.3 \\
2.0 \\
.5\end{array}$ & $\begin{array}{l}\text { Slight alteration. } \\
\text { Slight alteration. } \\
\text { Big broad twins. Alteration locally strong internally and on } \\
\text { boundaries, but not general. } \\
\text { Very mild strain. K-feldspar growing around plagioclase. } \\
\text { Feathery twins locally. }\end{array}$ \\
\hline
\end{tabular}

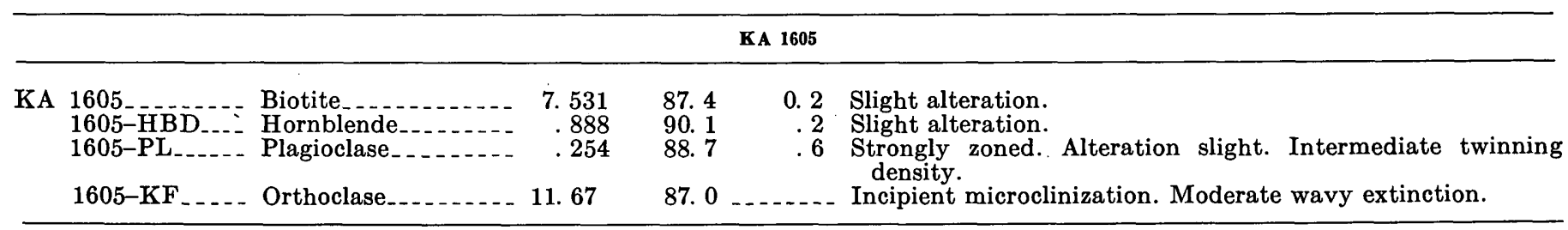


moved from the crucible. There was no trouble with blowing-out of samples.

The potassium values (high for quartz) are certainly not attributable to separate grains of feldspar. They may be due to feldspar inclusions in quartz, although none were noted in thin-section examination. The distinctly higher potassium value for KA $1569-\mathrm{QTZ}$ may indicate lack of removal of all altered plagioclase from the final concentrate, although the sample appeared as thoroughly fused as the others. If the data of the first four runs are averaged, the mean biotite age is $90.5 \mathrm{~m} . \mathrm{y}$. and the mean quartz age is $91.1 \mathrm{~m} . \mathrm{y}$.; the average values for all five runs are 92.8 m.y. and 84.5 m.y., respectively. The lack of any excess argon is obvious.

The environment of emplacement of the granitic rocks of the Sierra Nevada of California was such that no measurable excess argon was incorporated in any of the major minerals at time of formation, emplacement, or cooling of the plutons. Shallow emplacement, with correspondingly low confining pressure on gas content of residual fluids, is suggested by this result. Incidentally, we have found excess argon in the quartz of the Precambrian gneisses investigated by Hart (1964), in two samples of pegmatitic quartz, and in a quartz cobble from the Precambrian Witwatersrand conglomerates (unpub. data, Univ. California, Berkeley). Rama, Hart, and Roedder (1965) have reported excess argon in samples of pegmatitic and vein vuggy quartz.

\section{GEOLOGIC INTERPRETATION}

\section{GENETIC SIGNIFICANCE OF POTASSIUM-ARGON AGES OF BIOTITE AND HORNBLENDE}

\section{POTASSIUM-ARGON AGE IN PLUTONS OF CATHEDRAL PEAK TYPE}

We shall now be concerned solely with the ages obtained on biotites and on biotite-hornblende pairs. We shall assume that the patterns of ages observed have some genetic significance and shall attempt to understand the genesis of the pluton complex by a study of these ages. We shall also assume that the observed pattern of ages in these minerals is due to a complex intrusion and cooling history, that is, that argon diffusion and loss is largely a heat-dependent phenomenon. Also, we shall assume that we have largely avoided the problem of age being a function of potassium content in biotite by using carefully picked concentrates. As discussed in the first part of the report, we seem to have not completely escaped this problem in the Cathedral Peak pluton, but if this factor does not confuse the data any more than it does in that pluton, the major conclusions to be drawn from the entire body of data will be valid.

There were two main reasons for selecting plutons of Cathedral Peak type for detailed study. First, field re- lationships indicate they are virtually the youngest plutons of appreciable size in the Sierra Nevada. Reheating effects of later plutonism should be nonexistent, and the observed pattern of ages should reflect the pattern of emplacement and initial cooling. Secondly, plutons of this extremely distinctive rock type occur as a sequence of narrow elongate bodies along 160 miles of the Sierran crest (fig. 2,3). The rock is a quartz monzonite typified by very large microcline phenocrysts. In several places, field mapping has not yet defined the limits of the plutons, such areas being indicated by question marks in the figures. All contacts with older rocks are essentially vertical wherever they have been clearly observed. These plutons must be considered, on the basis of field evidence, to be discrete bodies for considerable distances below the surface.

Consider first the data of the Cathedral Peak pluton. An earlier discussion showed the correlation of apparent age and potassium content. It was there shown that determined ages of carefully picked high-potassium concentrates were not strongly affected by their small chlorite content. In the present discussion, the significant points are that in carefully picked high-potassium concentrates there does not seem to be any correlation of apparent age with elevation or with east-west position but that there is a definite correlation of age with northsouth position - the south end seems to be 2 to $3 \mathrm{~m}$.y. older than the northern end. Since age does not seem to be a function of elevation in the pluton, an explanation of the north-south difference cannot be found in a hypothesis of pronounced tilting of the pluton. A difference due to depth of erosion is completely ruled out by field evidence. Also, if age is independent of depth, then emplacement was shallow (see below) and cooling subsequent to final emplacement was rapid; the explanation that ages are based upon the complex pattern of cooling of a pluton emplaced at all points at nearly the same time is improbable. The only hypothesis that would seem to fit the facts is one that assumes shallow emplacement and a spread of 2 to 3 m.y. in the time of final emplacement of the two ends of the pluton, that is, a history that allows final cooling of the two ends of the pluton to have been separated by 2 to 3 m.y.

The data from the Sonora pluton (fig. 2) suggest age to be a function of east-west position rather than northsouth or vertical positions. In the Recess pluton (fig. 3), the few data suggest no dependence of age on northsouth position, are suggestive of a correlation of age and elevation (1 m.y. per 2,000 ft), and unequivocally indicate this pluton to be younger than either of the more northerly plutons. The contrast in age between the southern end of the Cathedral Peak pluton and the northern end of the Recess pluton cannot be explained on the basis of tilt during uplift of the mountain range. 


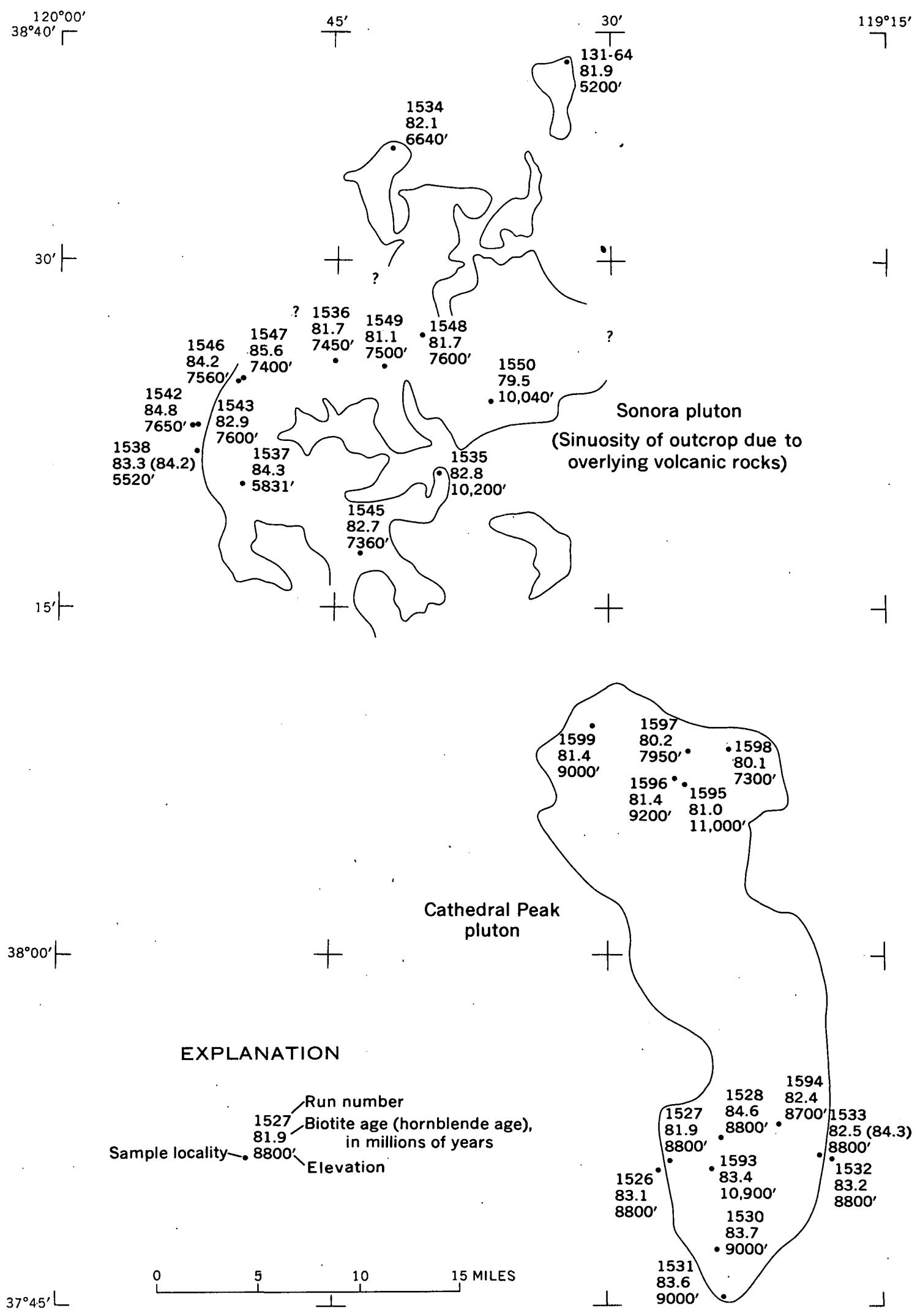

Figure 2.-Potassium-argon dates on samples from plutons of Cathedral Peak type, Sonora and Cathedral Peak plutons. 

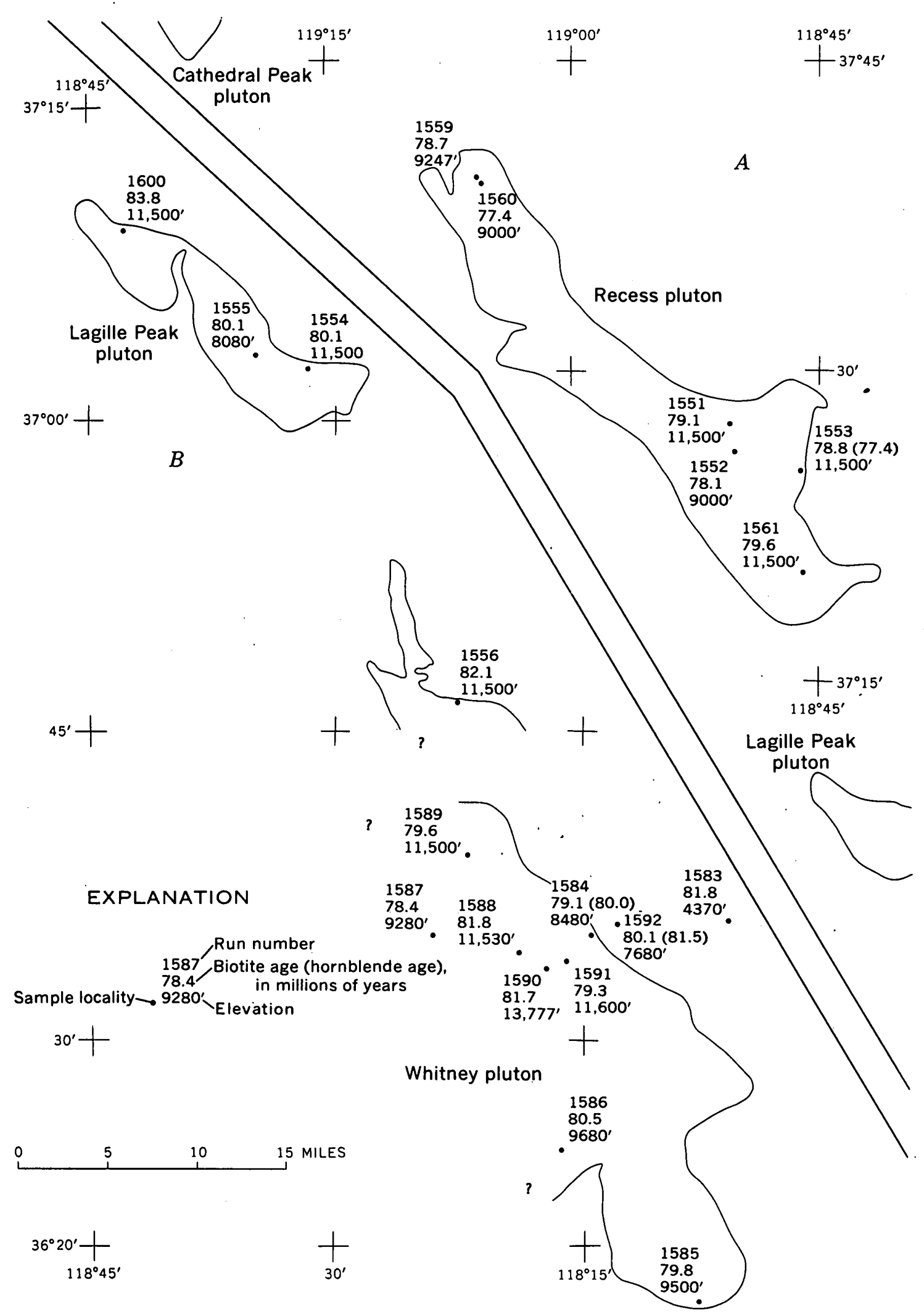

Frgure 3.-Potassium-argon dates on samples from plutons of Cathedral Peak type. $A$, Recess pluton; $B$, Whitney pluton. 
The data from the Lagille Peak pluton (fig. 3) are too limited to warrant detailed analysis.

The pattern of ages in the Whitney pluton is not well placed for a study of the relation between age and potassium content, since the samples were selected to investigate age as a function of position. Only subsequent to sample collection did the results from the Cathedral Peak pluton become available.

If the absolute age data obtained in the Whitney pluton are interpreted in terms of dipping isochronal surfaces, a correlation between east-west position, elevation, and age appears-the isochrons dipping about $7^{\circ}$ westward and having a perpendicular separation of about 600 feet for a time difference of 1 m.y. This conclusion is based upon a somewhat arbitrary analysis of the data, but it is interesting that this part of the Sierra is thought to have had much greater uplift and associated erosion than the area to the north (the general absence of roof pendants being considered significant). If relative uplift and erosion have been measured in thousands of feet, the appearance southward of age as a function of elevation is not surprising. It is concluded that there is no linear trend in the order of emplacement of the Cathedral Peak type plutons but that there is an increasing dependence of age upon elevation southward (for Cathedral Peak pluton, no observable change in age for 4,000 ft; Recess pluton, 1 m.y. per 2,000 ft; Whitney pluton, 1 m.y. per $600 \mathrm{ft}$ ).

Three biotite-hornblende pairs support the conclusion that several millions of years were involved in the emplacement of these quartz monzonite plutons: KA 1533 (82.5 m.y.) and KA 1533-HBD (84.3 m.y.) from the Cathedral Peak pluton; KA 1553 (78.8 m.y.) and KA 1553-HBD (77.4 m.y.) from the Recess pluton; and KA 1584 (79.1 m.y.) and KA 1584-HBD (80.0 m.y.) from the Whitney pluton. The internal agreement of each pair implies real significance for the age indicated by each pair, and the spread of mean ages of the three pairs implies real differences in the age of each pluton.

\section{DEPTH OF EMPLACEMENT OF THE SIERRAN PLUTONS}

The data we shall use to determine the depth of emplacement of the Sierran plutons are the data on the relation of age to elevation in the Cathedral Peak-type plutons. Such an approach to evaluating depth of emplacement must be based upon a heat model of granite emplacement and cooling. We are at once upon uncertain ground. But if the tenuousness of the fabric being woven is fully appreciated, no harm results from such discussions, and possibly some useful ideas may result.

The required parameters of the problem are several. First, one must assume the existence and value of a steady-state temperature gradient. This can be generated either by radioactivity within the upper $25 \mathrm{~km}$ of the crust or by a heat source below the upper layers. As it will not make any particular difference in the results, the latter model is chosen because of its ease of handling. A maximum of $33^{\circ} \mathrm{C}$ per km and a minimum of $25^{\circ} \mathrm{C}$ per $\mathrm{km}$ are suggested by heat flow and borehole data as limits of permissible gradients. For reasons discussed below, the gradient is achieved by holding the temperature constant at $800^{\circ} \mathrm{C}$ at the appropriate depth. If we consider that the data previously obtained on argon diffusion in phlogopite and glauconite by Evernden, Curtis, Kistler, and Obradovich (1960) are relevant to biotite under a load of several kilometers, some conclusions are immediately possible. First of all, note that one of the figures given in this earlier work is not correct. As pointed out by Paul Damon, the appropriate time interval to go with the listed $f$ values is $10^{6}$. years rather than $10^{5}$ years. Therefore, an $f$ value of 0.4 is to be associated with $325^{\circ} \mathrm{C}$ for biotite grains with a significant diffusion dimension of 1 millimeter. Since the significant diffusion dimension for biotite grains of Sierran rocks is probably less than 1 millimeter, $325^{\circ} \mathrm{C}$ is certainly beyond the temperature range at which rocks of nearly the same age could remain for 2 to 3 m.y. and still display differences in age on the order of a few million years. With a surface temperature of $30^{\circ} \mathrm{C}$, the $300^{\circ} \mathrm{C}$ isotherm of the model is pertinent. Factors inconsistent with emplacement of these plutons at depths where the ambient temperature is $325^{\circ} \mathrm{C}$ are the biotite age differential between the southern end of the Cathedral Peak pluton and the north end of the Recess pluton; the concordance of the biotite-hornblende pair from KA 1533 (Cathedral Peak pluton); and the lack of any dependence of age upon elevation in the Cathedral Peak pluton. The levels now exposed of these pluton ends were certainly at the same depth at all times since emplacement of the younger. If they were ever both at $325^{\circ} \mathrm{C}$ at the same time, they would certainly show essentially identical ages today, would probably display discordant biotite-hornblende ages, would display age as a function of elevation, and the two ends of the Cathedral Peak pluton would not show different apparent ages. Thus, on the argument of geothermal gradient alone, the maximum permissible depth for the top of the plutons is less than $12 \mathrm{~km}$ for $25^{\circ} \mathrm{C}$ per $\mathrm{km}$, or $9 \mathrm{~km}$ for a gradient of $33^{\circ} \mathrm{C}$ per $\mathrm{km}$.

What is the temperature of a pluton at the time of "initiation of cooling"? We shall not attempt to discuss the period of time involved in emplacement of a pluton or the temperature history during that time. We presume that we can establish a temperature distribution of approximately the correct type for the period when 
cooling became the ruling heat process. The model will be designed to err on the side of a low estimate of heat in the pluton after "initation of cooling" so that the estimate of depth of emplacement will be a maximum.

The geologic thermometer used to establish the temperature at time of "initiation of cooling" is the mineral assemblage found in roof pendants, zenoliths, and metamorphic aureoles of the plutons. Bateman, Clark, Huber, Moore, and Rinehart (1963) can be consulted for a discussion of these metamorphic rocks and their mineral assemblages. The essential feature is that they are predominantly hornblende hornfels with a small percentage of pyroxene hornfels, and locally display both wollastonite- and calcite quartz-bearing phases as well as andalusite- and sillimanite-bearing phases. Therefore, the mean temperature condition during the genesis of these rocks was in the pressure-temperature region where the three phase boundaries of figure 4 intersect. The andalusite-sillimanite data (Weill, 1966) are essential to the argument. The calcite quartz-wollastonite data are from Ellis and Fyfe (1956) and the pyroxene hornfels-hornblende hornfels curve is from Fyfe, Turner, and Verhoogen (1958). The PH-HH curve is hypothetical and can move appreciably in response to varying total composition of the rock, but it is thought to be at very nearly the correct position for rocks of granitic composition. The conclusion is that a temperature of approximately $600^{\circ} \mathrm{C}$ is predicted for rocks forming near these phase-boundary intersections. Since such a temperature implies that the granitic mass was largely crystalline at this time, heat of crystallization can be disregarded.

The heat model at time of "initiation of cooling" is then $800^{\circ} \mathrm{C}\left(800^{\circ} \mathrm{C}\right.$ is adequate, as this is well above $600^{\circ} \mathrm{C}$ ) held constant at the appropriate depth, geothermal gradient to $600^{\circ} \mathrm{C}, 600^{\circ} \mathrm{C}$ to depth $D$ below the surface, and a uniform gradient to the surface (fig. $5 A$ ). No account is taken of lateral cooling, for the Cathedral Peak pluton and the surrounding portions of the Half Dome pluton show no lateral variations in age. The ages in the Half Dome pluton near the contact with the Cathedral Peak pluton are indistinguishable from those of the Cathedral Peak pluton, and the dates within the latter are uniform from edge to edge. The final step is to cool this mass to the geothermal gradient by conduction without introduction of additional heat. As can be seen, every theoretical departure from the actual environment is probably in the direction of underestimating heat available. The computations were carried through for several values of $D$ (depth of emplacement). Figure $5 B$ shows the position of the $300^{\circ} \mathrm{C}$ isotherm as a function of $D$, depth of emplacement; $d$, depth into the pluton; and $t$, time in $10^{6}$ years since initiation of cooling.

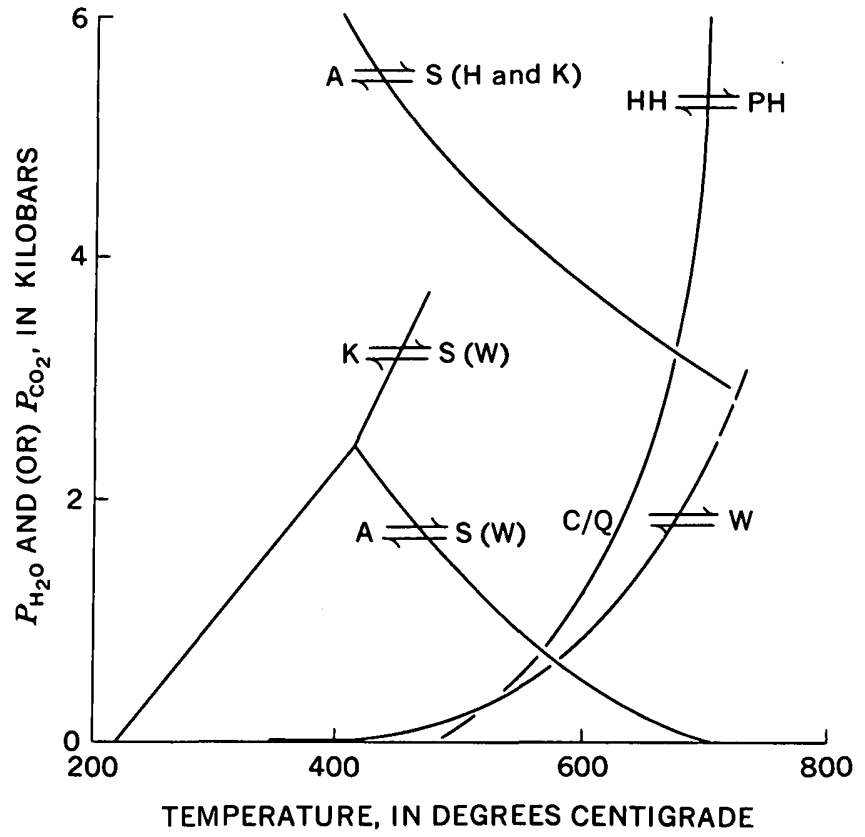

EXPLANATTON

Kyanite-sillimanite-andalusite (K-S-A) curves. Curves from Well (1966) are designated (W) ; curve from Holm and Kleppa (1968) is designated ( $H$ and $K$ ).

Wollastonite-calcite/quartz (W-C/Q) curve from Ellis and Fyfe (1856).

Pyroxene hornfels-hornblende hornfels (PH-HH) curve from Fyfe, Turner, and Verhoogen (1958).

Fraure 4.-Pressure-temperature fields for metamorphic mineral and rock pairs.

We will use the $300^{\circ} \mathrm{C}$ of our model as our guide temperature for the reasons stated. We will also assume that the pattern of movement of this isotherm in the cooling pluton is reflected quite closely in the pattern of age in relation to elevation in the pluton today. In the discussion which follows, figures not in parentheses refer to a $33^{\circ} \mathrm{C}$ per $\mathrm{km}$ gradient; figures in parentheses refer to a $25^{\circ} \mathrm{C}$ per $\mathrm{km}$ gradient. Note first the data for $D=8(11) \mathrm{km}$. At the top of the pluton, the $300^{\circ} \mathrm{C}$ isotherm subsides $0.7 \mathrm{~km}$ in $10^{6}$ years $\left(0.7 \mathrm{~km}\right.$ in $1.8 \times 10^{6}$ years). At greater depth (the tops of all the plutons are now eroded), this isotherm subsides more slowly. Assuming the validity of the assumption made above, it can be stated that a pluton emplaced at 8 (11) $\mathrm{km}$ depth must show age as a function of elevation at least to the level $10^{6}$ years within 2,000 feet $\left(1.8 \times 10^{6}\right.$ years within 2,000 feet). Such is not observed in the Cathedral Peak pluton and so such values of $D$ are inadmissible.

For $D=4(5.5) \mathrm{km}$, age as a function of elevation at the top of the pluton is predicted to be $0.6 \times 10^{6}$ years within $1.8 \mathrm{~km}\left(1.1 \times 10^{6}\right.$ years within $\left.1.8 \mathrm{~km}\right)$, while at $2.5 \mathrm{~km}$ depth within the pluton $(d=2.5)$ a rate of $10^{8}$ years within $1.4 \mathrm{~km}\left(1.8 \times 10^{6}\right.$ 


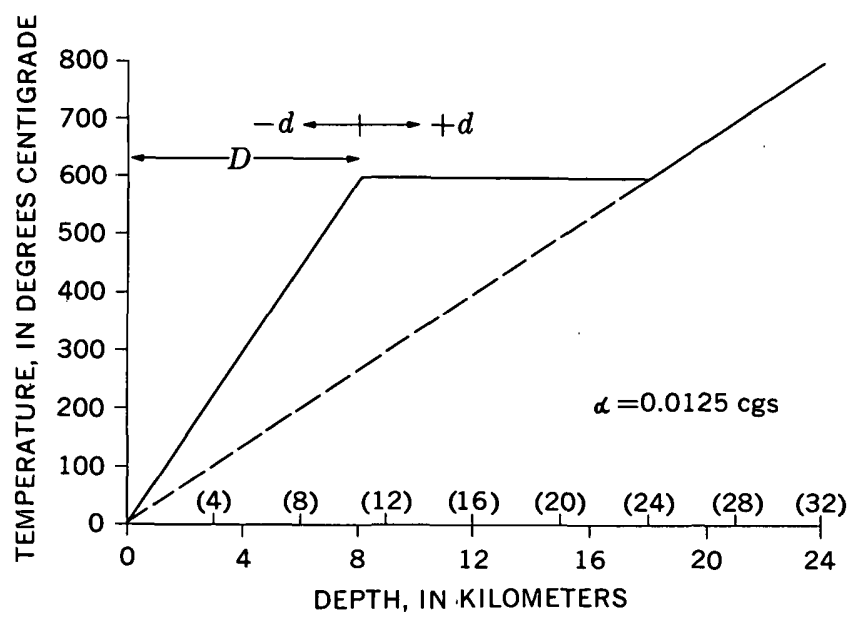

$A$

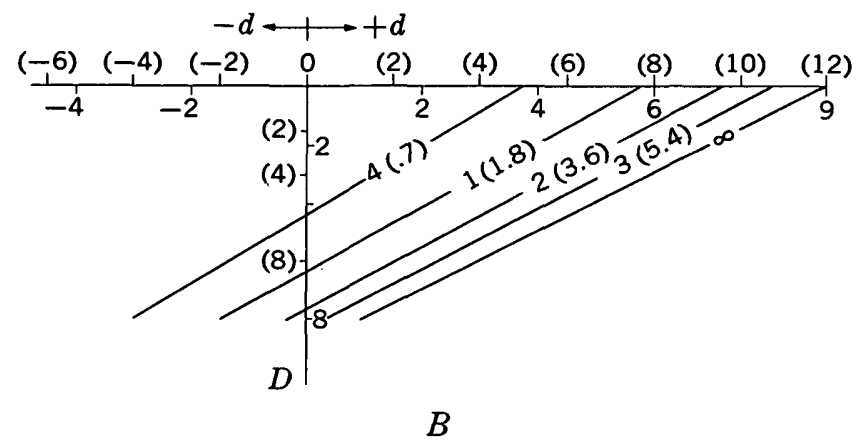

Figure 5.-Heat model for intrusive rocks of the Sierra Nevada. Numbers in parentheses refer to a $25^{\circ} \mathrm{C}$ per $\mathrm{km}$ geothermal gradient. Numbers not in parentheses refer to a $33^{\circ} \mathrm{C}$ per $\mathrm{km}$ geothermal gradient. A. Assumed temperature distribution at "initiation of cooling" and geothermal gradient. $B$. Position of $300^{\circ} \mathrm{C}$ isotherm as function of $d$ (depth into pluton), $D$ (depth of emplacement), and $t$ (time in $10^{\circ}$ years since "initiation of cooling").

years within $1.4 \mathrm{~km}$ ) is predicted. Whether a $D$ of 4 $\mathrm{km}$ is admissible depends upon the depth of erosion of the pluton today. In any case, a $D$ of $6 \mathrm{~km}$ is inadmissible on this model. Note that the suggested gradients in the Recess and Whitney plutons can be found on the profile for $D=5 \mathrm{~km}$ or less at values of $d$ of a very few kilometers. Thus, the entire pattern of observed gradients can be explained by intrusion to depths of $5 \mathrm{~km}$ or less and subsequent pronounced tilting of the batholith. Such tilting has often been invoked to explain the lack of roof pendants in the Mount Whitney area.

Is this prediction of shallow emplacement supported or denied by other data? Broad-scale field investigations tend to support such shallow depths of emplacement because of the demonstrably short interval of geologic time between emplacement and unroofing by erosion of such plutons and because of the known thickness of sediments which accumulated as a result of erosion between the time of emplacement and exposure of the plutons (Curtis and others, 1958). Bateman, Clark, Huber, Moore, and Rinehart (1963) have argued for a depth of emplacement of Sierran plutons of $15 \mathrm{~km}$, basing their arguments on the mineralogy of the metamorphic and igneous rocks. As regards the metamorphic rocks, the present uncertainties in position of the plotted sillimanite-kyanite-andalusite triple point make impossible any detailed conclusions on temperature and depth of emplacement of these plutons based upon position of this triple point. Reference should be made to the article by Holm and Kleppa (1966) in which the various computed positions of the sillimanite-kyaniteandalusite phase boundaries are plotted. The phase boundaries as plotted by Weill (1966) agree nicely with our heat-flow analysis. The essential point for our analysis is the intersection of the sillimanite-andalusite and the wollastonite-calcite/quartz curves. Based on Weill's data, a temperature of approximately $600^{\circ} \mathrm{C}$ and a $P_{\mathrm{H}_{2} \mathrm{O}}=P_{\mathrm{CO}_{2}}$ of 0.8 kilobars are predicted as the temperature-pressure conditions for genesis of the observed metamorphic mineral assemblages in the Sierra Nevada. If $P_{\mathrm{H}_{2} \mathrm{O}}$ is presumed to be equal to $P_{\text {load, a }}$ depth of emplacement of $3 \mathrm{~km}$ is predicted, whereas if $P_{\mathrm{H}_{2} \mathrm{O}}$ is hydrostatic, a depth of $8 \mathrm{~km}$ is predicted. Therefore, there is no conflict with the depths predicted by the heat-flow model. The data of Holm and Kleppa, together with the wollastonite-calcite/quartz data of Ellis and Fyfe (1956), predict that the temperature-pressure conditions necessary for genesis of these rocks are $700^{\circ} \mathrm{C}$ and $3 \mathrm{~kb}$. At present, we see no obvious way to decide on the relative merits of the investigations of Weill (1966) and Holm and Kleppa (1966). The conclusion must be that the mineralogical data predict temperatures between $600^{\circ} \mathrm{C}$ and $700^{\circ} \mathrm{C}$ and pressures of 0.8 to $3.0 \mathrm{~kb}$ with no more refined specification possible. Bateman's argument based upon the composition of the granitic rocks has two flaws well known to him. First, it was necessary to argue about the anorthite-albite-orthoclase system while possessing only data on the albite-orthoclase system. For this reason, one cannot evaluate the soundness of his argument as applied to granites of the Sierra Nevada area. Secondly, much crystallization may well have taken place prior to final emplacement of the pluton. Therefore, we can state that neither of Bateman's thermometers is sufficiently well calibrated to allow prediction of depth of emplacement of the Sierran plutons. There is no clear demonstrable disagreement of the mineralogical data with our conclusions. 


\section{DISCORDANT BIOTITE-HORNBLENDE PAIRS- EVIDENCE OF REHEATED PLUTONS}

The gross discordances in potassium-argon ages of biotite-hornblende pairs from specimens of granitic rock found by Kistler, Bateman, and Brannock (1965) on the east side of the Sierra Nevada and further data in this report are clear evidence that old granitic rocks (180-210 m.y.) were reheated by much younger plutons (90-80 m.y. old).

The numerous discordant samples reported by Kistler, Bateman, and Brannock (1965) are shown on plate 2. The samples that displayed marked discordance (greater than 5 m.y.) in the present study are given in the following table.

Samples in present study that show discordance greater than 5 m.y.

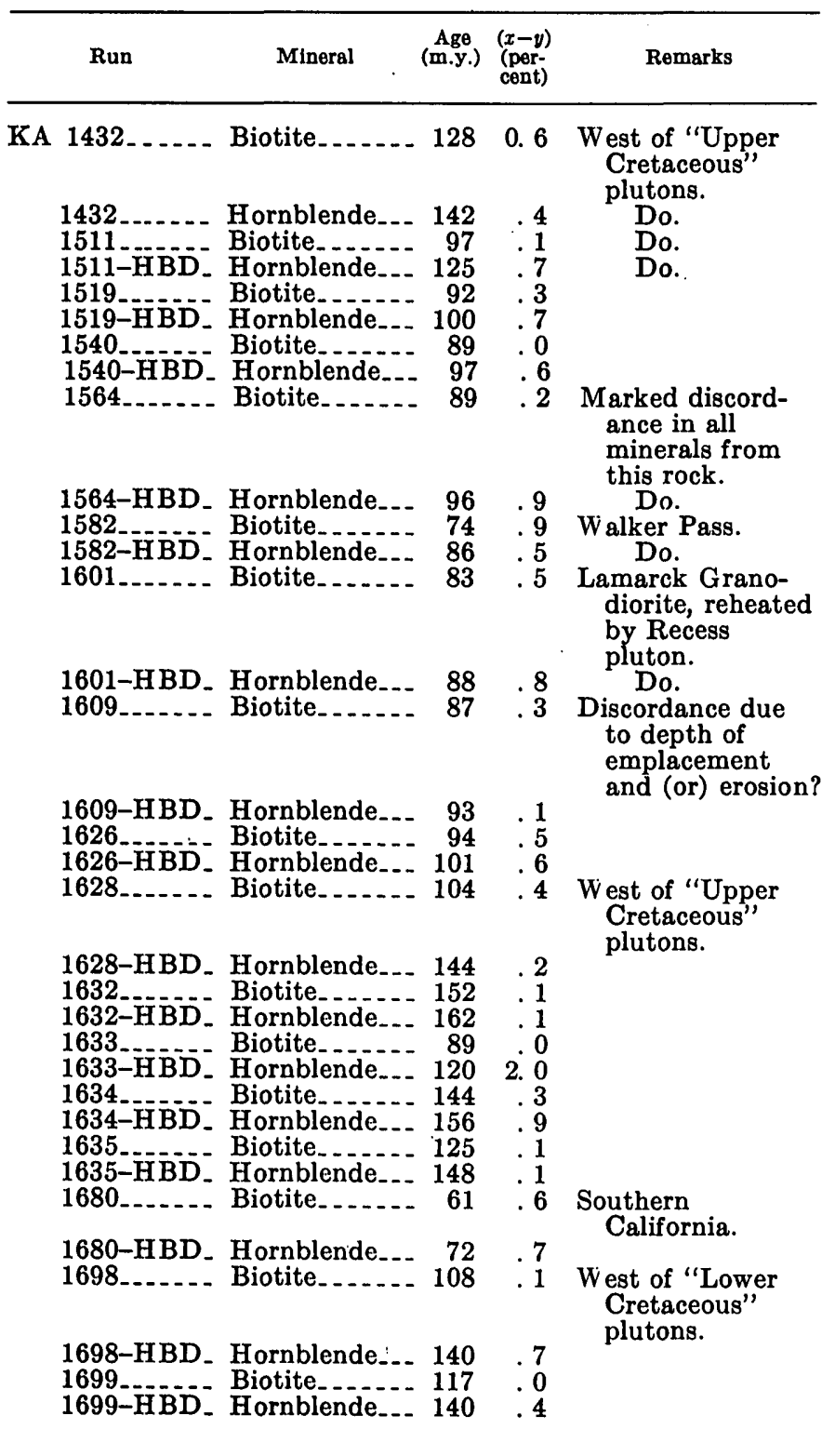

Samples in present study that show discordance greater than 5 m.y. -Continued

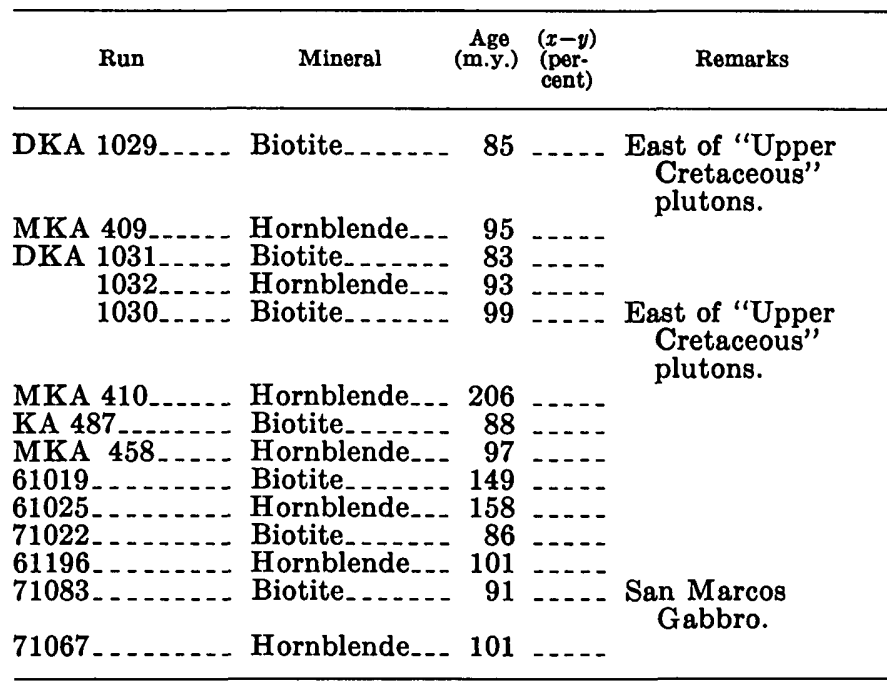

The argument of this section and the following ones will depend strongly upon the data of Hart (1964). Hart demonstrated the concordance of biotite and hornblende ages can indicate either initial cooling or degassing of both minerals by a later event. Concordance does imply a heating-cooling event, however. The pattern of discordance displayed by Hart's data is extremely important. The biotite, along the profile sampled by Hart, lost all of its argon before the hornblende indicated other than the uncertain indication of a 15 percent loss at great distance. Thus the pattern of discordance expected along a profile of reheating in the older mass will not be one showing near-concordance of biotite and hornblende at all distances, the age changing gradually from older to younger, but rather concordance beyond the effect of the younger pluton, with increasing discordance until the biotite reaches the age of the younger pluton, and only there, or farther on toward the younger intrusive, the decrease of hornblende ages to concordance with the biotite age. $A$ series of ages such as that at " $A$ " on plate 2 is the expected result of reheating by a single later event. In that area, the older rocks are to the west, the younger to the east. The sequence of determined ages from west to east, that is, towards the younger intrusive is:

\begin{tabular}{|c|c|c|c|}
\hline \multirow[b]{2}{*}{ Run } & & \multicolumn{2}{|c|}{ Age (m.y.) } \\
\hline & & Biotite & Hornblende \\
\hline KA & 1700 & ........ & 138 \\
\hline & 1699 169 & 117 & 140 \\
\hline & 1698 & 108 & 140 \\
\hline & 1683 & 102 & 100 \\
\hline
\end{tabular}

Field evidence and lithology of sample KA 1683 suggest that it is from the older granites (more acidic than rocks to east, evidence of extensive recrystallization, deu- 
teric alteration of most minerals, and strong distortion of biotites). Reheating with consequent argon loss is clearly shown in the series at " $B$ " on plate 2 and by numerous other samples on the western side of the Sierra.

\section{CONCORDANT BIOTITE-HORNBLENDE PAIRS- EVIDENCE OF THE AGE OF AN INTRUSIVE EVENT}

We shall classify as concordant those pairs of ages which agree to within $5 \mathrm{~m}$.y., such a degree of concordance being interpreted to mean that the pair of ages quite closely date an intrusive event, either that of the rock dated or that of an adjacent intrusive. In order of determined age, the concordant pairs are as follows:

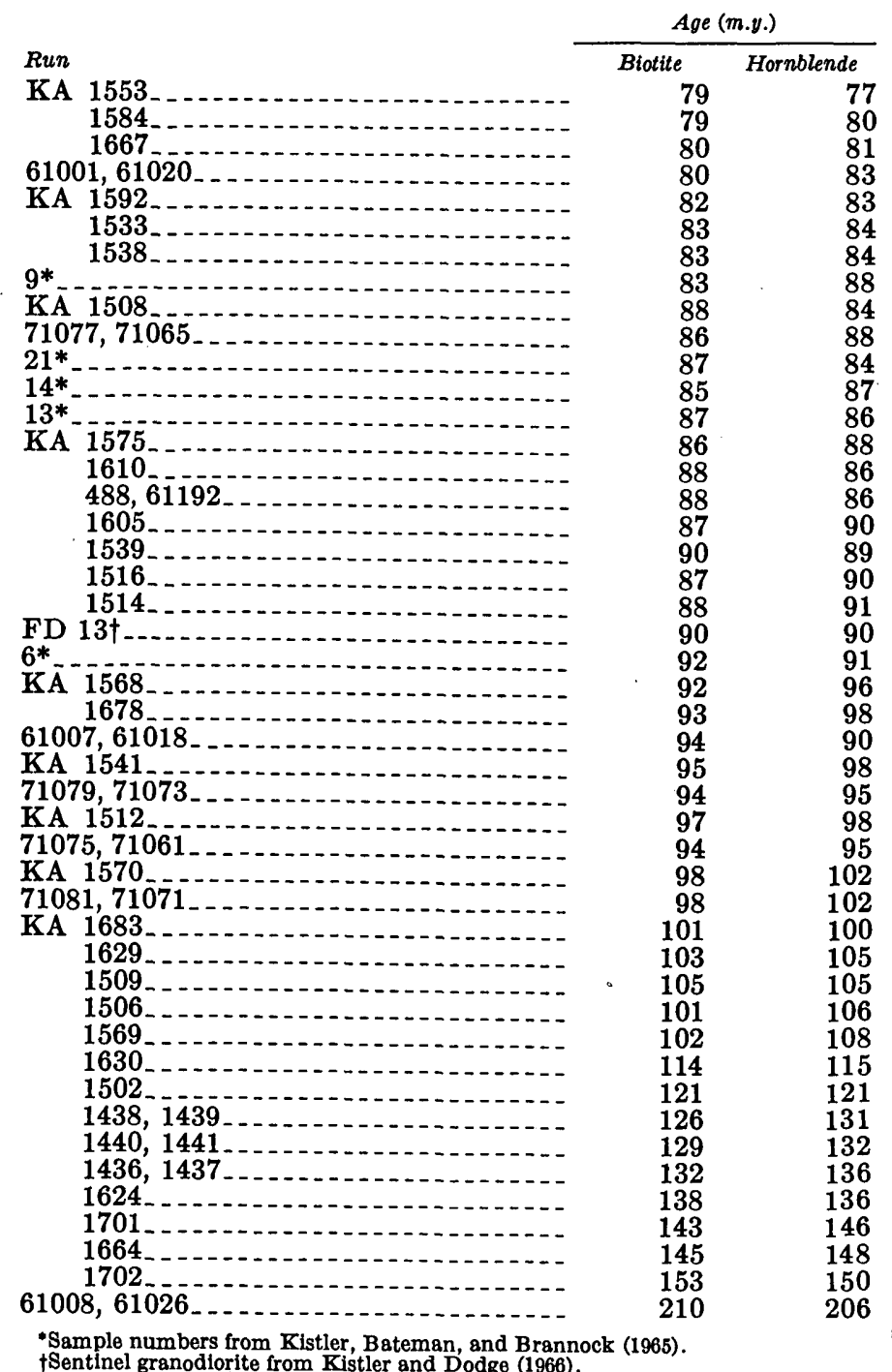

The greater number of ages within the range 80 to 108 m.y. is largely the result of the sampling pattern and is not to be considered significant in interpretation. Rather, the distribution of rocks according to age groups as shown on plate 1 is a more accurate estimate of the relative significance of each age interval in the genesis of the batholith. These data show that no concordant pair of ages is lacking for any significant time interval after an age of $150 \mathrm{~m} . y$. Certainly, there are two periods of 10 million years for which there are no ages, but the chances seem good that those intervals could be filled by selective sampling. The concept of several distinct periods of granite emplacement separated by long intervals of no granite emplacement (Curtis and others, 1958; Kistler and others, 1965) is not supported by the total body of potassium-argon ages. A more reasonable interpretation of the mineral age data is that granite emplacement in the environs of the Sierra Nevada was an essentially continuous process covering the period from 210 m.y. ago up to approximately 80 m.y. ago. As will be discussed below, the volume of granite emplaced in equal intervals of time was probably grossly different and the pulses of orogeny that geologists have defined in this area seem to be culminations of activity of a basically continuous process.

Therefore, the two areas of granitic terrane-eastern Australia and the Sierra Nevada-in which ages have been reasonably well studied on a broad scale yield the same answer. Granite genesis and emplacement can be a nearly continuous process for more than 100 m.y. It will be shown below, however, that the continuity of emplacement of plutons in the Sierra Nevada is actually the result of a series of pulses of granite genesis and emplacement which yield a continuous series of ages because of complex mechanical and thermal histories. The spacing of the pulses and the time required for the completion of each give the continuity of concordant potassium-argon ages.

\section{GROWTH OF THE SIERRA NEVADA BATHOLITH}

We here consider the pattern of ages obtained by all techniques throughout the Sierra Nevada and its environs in order to clarify the preceding discussions of continuity in magmatic activity during the Mesozoic Era. The total body of data available, including ages obtained by potassium-argon, rubidium-strontium, and lead-alpha methods indicates that five major epochs of intrusion by granitic magma occurred from the Middle Triassic to the Late Cretaceous at intervals of approximately 30 million years. We identify each epoch by numerical age representing the oldest known age correlated with that epoch; they are in the sequence 210, 180, 148,121 , and 90 m.y. Distinctly mappable granitic rock series that were emplaced during each of these intrusive epochs have been well defined in California by comprehensive work in different areas by several field geologists (Calkins, 1930; Bateman and others, 1963; Kistler, 1966b). We shall first discuss the distribution of ages 
shown by all methods in these well-known areas (see outlined area, pl. 1) and then extrapolate to other areas on the basis of our potassium-argon data on biotite and hornblende.

\section{CATHEDRAL RANGE INTRUBIVE EPOCH OF LATE} CRETACEOUS AGE

The Cathedral Range intrusive epoch is here defined as the time of emplacement of granitic rocks of the Tuolumne Intrusive Series. This is the younger of two series of granitic rock in the Yosemite region of the Sierra Nevada that were defined by Calkins (1930). The younger series includes the Sentinel Granodiorite, Half Dome Quartz Monzonite, Cathedral Peak Granite and Johnson Granite porphyry. Subsequent mapping by other investigators has shown that rocks of the Tuolumne Intrusive Series occur along the crestal regions of the Sierra Nevada for its entire length (Mayo, 1941; Bateman, 1961; Broderson, 1962) and that these rocks represent the youngest intrusions in the batholithic complex. Dates for rocks of the Tuolumne Intrusive Series have been obtained by the potassium-argon method using mineral separates (Curtis and others, 1958; Kistler and others, 1965; Kistler and Dodge, 1966; and many more determinations in this report), by rubidiumstrontium isotope analyses of whole rocks (Hurley and others, 1965) and by the lead-alpha method (Jaffe and others, 1959; Bateman and others, 1963). The maximum age for the oldest member of the series, the Sentinel Granodiorite, by concordant potassium-argon dates on hornblende, biotite, and orthoclase from the same specimen of rock, is 90 m.y. (Kistler and Dodge, 1966). The lead-alpha age of uranothorite from the Half Dome Quartz Monzonite, the next younger member of the series, is $88 \mathrm{~m}$.y. (Jaffe and others, 1959); ages on zircons from the Lamarck and Round Valley Peak Granodiorites are 91 and 88 m.y., respectively (Bateman and others, 1963). According to Hurley, Bateman, Fairbairn, and Pinson (1965), a rubidiumstrontium whole-rock isochron of 90 m.y. can be constructed with the analyzed specimens of the Mount Givens and Lamarck Granodiorites and later quartz monzonites from this series. All of the age data together indicate that the first increment of magma of the Tuolumne Intrusive Series was intruded 90 m.y. ago. The spread of concordant mineral ages from 90 m.y. to 79 m.y. is the maximum interval of time available for the intrusion of the tremendous volume of magma represented by these rocks and for the cooling of this mass to a temperature low enough to permit equal retention of radiogenic argon in biotite and hornblende (about $300^{\circ} \mathrm{C}$, see page 12). Some of the spread in ages is due to the mechanisms discussed in other sections of this paper, but ages of mineral pairs from rocks emplaced during the Cathedral Range intrusive epoch are generally concordant and date the event as Late Cretaceous.

\section{HUNTINGTON LARE INTRUSIVE EPOCH OF EARLY CRETACEOUS AGE}

The Huntington Lake intrusive epoch is here defined as the time of emplacement of the granitic rocks represented by the granodiorite of "Dinkey Creek" type in the Huntington Lake area, Fresno County, Calif. and correlative intrusive rocks elsewhere. The granodiorite of "Dinkey Creek" type mapped by Krauskopf (1953), Macdonald (1941), and Hamilton (1956) without delineation of individual plutons is a series of rocks rang. ing in composition from quartz diorite to quartz monzo. nite. The granodiorite of "Dinkey Creek" type in the vicinity of Huntington Lake is known from contact relationships to be older than the Mount Givens Granodiorite (Bateman and others, 1963). In the area where the "Dinkey Creek" type has been mapped, the maximum potassium-argon age of hornblende, determined from a quartz diorite at its westernmost exposure, is 115 m.y., and the biotite-hornblende pairs from dated specimens generally have discordant ages (Kistler and others, 1965). Ages approach concordance (KA 1630) and a maximum only in specimens collected far from the contact between the granodiorite of "Dinkey Creek" type and rocks of the Tuolumne Intrusive Series to the east. A whole-rock rubidium-strontium isochron for a granodiorite of "Dinkey Creek" type exposed near Huntington Lake yields an age of $104 \mathrm{~m} . \mathrm{y}$. (fig. $6 \mathrm{~A}$; table 4).

Other granitic rocks intruded during the Huntington Lake intrusive epoch include some of the plutons in the southern California batholith and those in the Santa Lucia Mountains of the so-called Coast Range batholith. The rubidium-strontium whole-rock age for the Santa Lucia plutons is 117 m.y. (fig. 6B; table 4). Banks and Silver (1966) report isotopic uranium-lead ages between 109 and 116 m.y. for zircons from plutons in the southern California batholith. All the geochronologic data show that the Huntington Lake intrusive epoch spans the time interval 121 m.y. to 104 m.y. ago and is Early Cretaceous in age.

\section{YOBEMITE INTRUSIVE EPOCH OF LATE JORABSIC AGE}

The Yosemite intrusive epoch is here named for the time of emplacement of granitic rocks exposed in Yosemite Valley-its type area. These rocks include the biotite granite of Arch Rock, granodiorite of The Gateway, El Capitan Granite, and Taft Granite. It includes the so-called biotite granite series of the Yosemite Valley, which Calkins (1930, p. 121) dated as older 


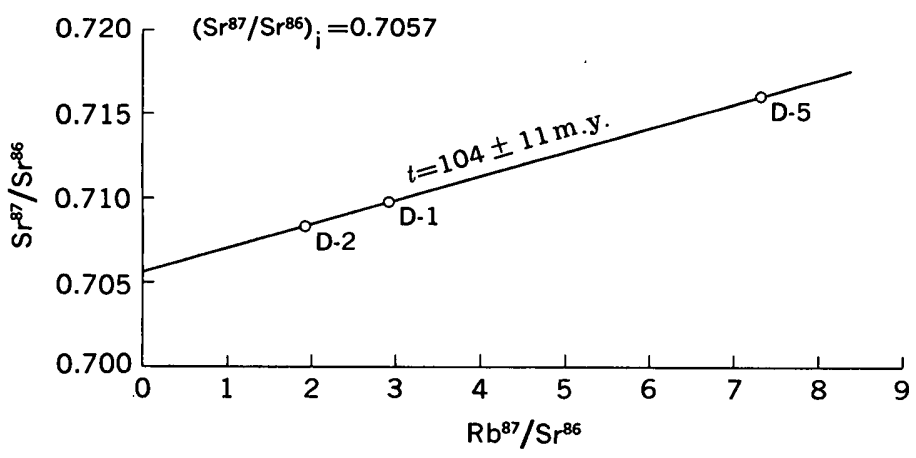

$A$

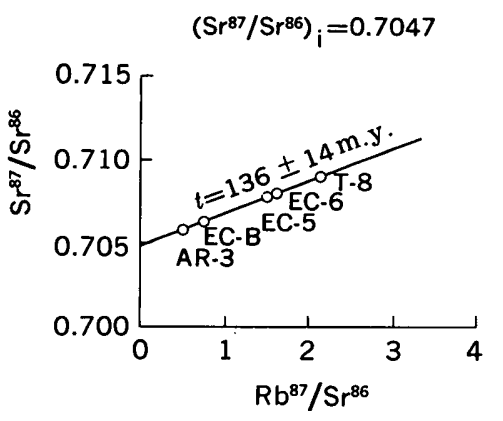

$C$

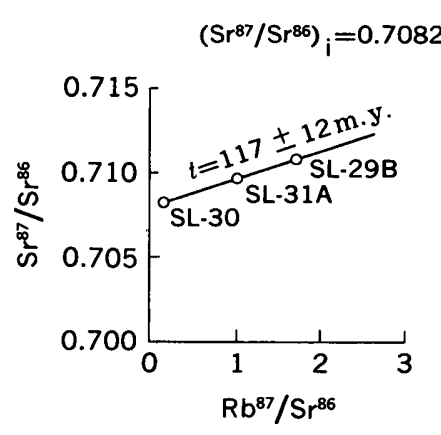

$B$

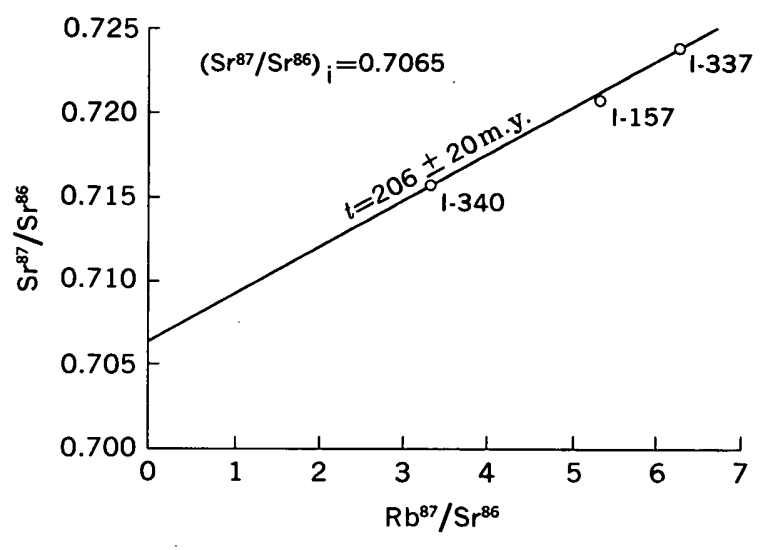

$D$

FIGURE 6.-Rubidium-strontium isochron plots for granitic rocks in California. A. Granodiorite of "Dinkey Oreek" type. $B$. Plutons of Santa Lucia Mountains. C. Granitic rocks of the Yosemite intrusive epoch. D. Quartz monzonite of Lee Vining Canyon. (Analytical uncertainty does not include the uncertainty in the $\mathbf{R b}^{87}$ decay constant.)

than his Tuolumne Intrusive Series because the Sentinel Granodiorite of the Tuolumne intrudes the El Capitan Granite.

Age determinations of rocks intruded during the Yosemite intrusive epoch have been obtained by potassium-argon analyses of biotite and hornblende (Curtis and others, 1958, and this report) and by rubidium-strontium isotopic analyses of whole rocks. The maximum mineral age (101 m.y.) for this series in the type area is for hornblende from a specimen collected at the most westerly outcrop of granodiorite of The Gateway (KA 1663), but rubidium-strontium analyses of whole-rock specimens of biotite granite of Arch Rock, El Capitan Granite, and Taft Granite yield an isochron of 136 m.y. (fig. $6 C$; table 4). The data suggest that the mineral ages from specimens in the Yosemite Valley area have all been reduced by various amounts by reheating during the later intrusions of the Tuolumne Intrusive Series to the east and the granodiorite of "Dinkey Creek" type to the south. The rubidiumstrontium age indicates the biotite-granite series of the Yosemite Valley to be a temporal equivalent of the Late Jurassic granitic rocks of the foothill belt to the west. The foothill granitic rocks generally have concordant biotite-hornblende potassium-argon ages between 148 and 136 m.y. (KA 1624), etc. All the geochronologic data show that the Yosemite intrusive epoch spans the time interval 148 to 132 m.y. ago and is Late Jurassic in age.

\section{INYO MOUNTAINS INTRUSIVE EPOCH OF EARIY AND} MIDDLE JURASSIC AGE

The name Inyo Mountains intrusive epoch is here assigned to the period of time when the majority of the plutonic rocks exposed in the Inyo and White Mountains and the Tinemaha Granodiorite and granodiorite of McMurray Meadows exposed in the Sierra Nevada were emplaced (Bateman, 1961; McKee and Nash, 1967). The Lamarck Granodiorite intruded during the Cathedral Range intrusive epoch is known from contact relationships to be younger than the Tinemaha Granodiorite in the area of exposures near the crestal region of the Sierra Nevada southwest of Big Pine, Calif. (Bateman, 1961).

Age determinations of rocks intruded during this epoch are from potassium-argon analyses of biotite and hornblende (Kistler and others, 1965; McKee and Nash, 1967 ; this report) and from lead-alpha ages of zircons 
TABLE 4.-Rubidium-strontium analytical data

[Banta Lucia Mountains samples analyzed by $R$. W. Kistler; all other analyses by Carl E. Hedge]

\begin{tabular}{lllll}
\hline Sample & $\begin{array}{c}\mathrm{Rb} \\
(\mathrm{ppm})\end{array}$ & $\begin{array}{c}\mathbf{S r}(\text { total }) \\
(\mathrm{ppm})\end{array}$ & $\mathbf{R b}^{87} / \mathrm{Sr}^{86}$ & $\mathrm{Sr}^{87 / \mathrm{Sr}^{86 *}}$ \\
\hline
\end{tabular}

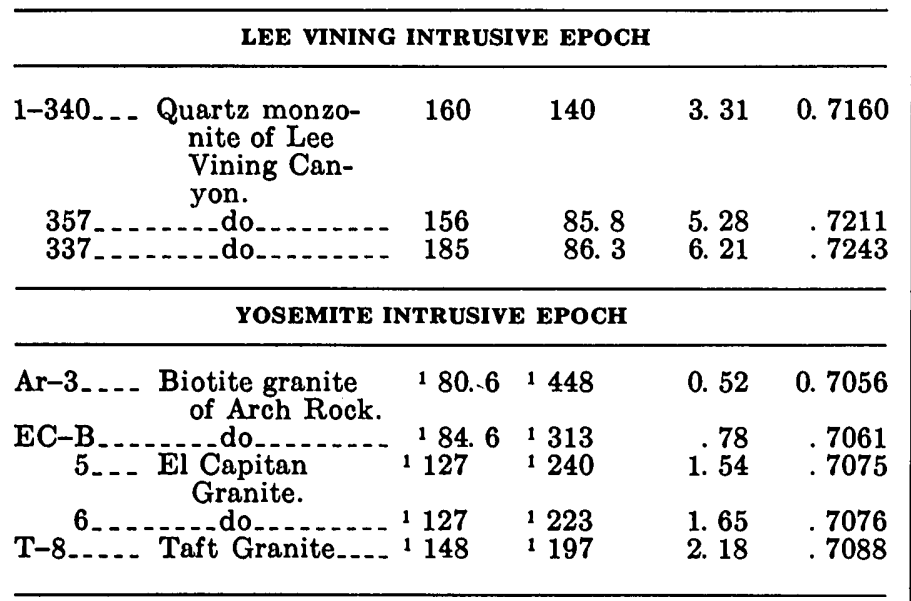

\begin{tabular}{|c|c|c|c|c|c|}
\hline \multicolumn{6}{|c|}{ HUNTINGTON LAKE INTRUSIVE EPOCH } \\
\hline D-1 $1 \ldots$ & $\begin{array}{l}\text { Granodiorite of } \\
\text { "Dinkey } \\
\text { Creek." }\end{array}$ & 208 & 208 & 2. 90 & 0.7098 \\
\hline $\begin{array}{l}2 \\
5-\ldots-\end{array}$ & - do do & $\begin{array}{l}173 \\
1270\end{array}$ & $\begin{array}{ll}1 & 264 \\
1 & 107\end{array}$ & $\begin{array}{l}\text { 1. } 91 \\
\text { 7. } 31\end{array}$ & $\begin{array}{r}7085 \\
.7162\end{array}$ \\
\hline
\end{tabular}

SANTa LUCIA MOUNTAINS, MaIN JUNIPERo SERRA PLUTON

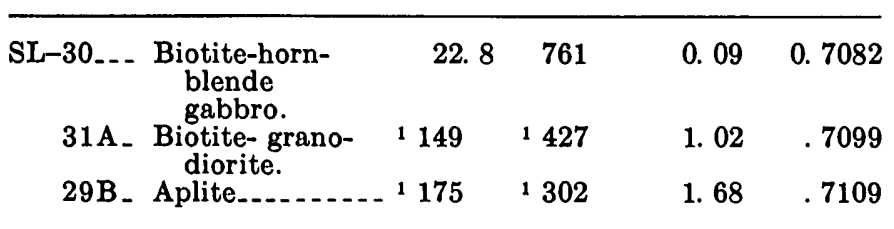

- $\mathrm{Sr}{ }^{37} / \mathrm{Sr} \mathrm{S}^{30}$ correctod for fractionation by normalizing observed $\mathrm{Sr}{ }^{80} / \mathrm{Sr}^{80}$ ratios to 0.1194 1 Rubldium and strontium concentrations by isotope dilution. All other concen trations by X-ray fuorescence. Constants:

$$
\begin{aligned}
\mathrm{Rb} \mathrm{b}^{87}: & \lambda_{\beta}=1.39 \times 10^{-11} \mathrm{yr}^{-1} \\
& 0.283 \mathrm{~g} / \mathrm{g} \mathrm{Rb}
\end{aligned}
$$

$\mathrm{Sr}^{87} / \mathrm{Sr}^{80}= \pm 0.0010$ at 05 percent confedence level for a single analysis. Rubidium and strontlum concentrations by isotope dilution are \pm 2.0 percent. Rubidium-strontium ratios determined by $X$-ray fluorescence are \pm 3.0 percent. Rock ages derived from the isochrons are \pm 10 percent owing to analytical uncertainty and to the small spread of $\mathrm{Rb} / \mathrm{Sr}$ ratios in most of the series in vestigated.

(Ross, 1965). Potassium-argon ages of biotite-hornblende pairs from most specimens are grossly discordant. The zircon ages, however, cluster around 180 m.y. and the maximum hornblende age is $183 \mathrm{~m} . \mathrm{y}$. (Kistler and others, 1965; Ross, 1965). Thus an age of approximately $180 \mathrm{~m} . \mathrm{y}$. is considered to mark the time of earliest intrusion by magma within this event. As in the other older granitic rocks, mineral ages of rocks of the Inyo Mountains intrusive epoch become more reduced and discordant with proximity to the Late Cretaceous granitic rocks near the crest of the Sierra Nevada. Hornblende potassium-argon ages indicate the Inyo Mountains intrusive epoch spans the time interval from 180 to 160 m.y. ago and is Early and Middle Jurassic in age.

\section{LEE VINTNG INTROSIVE EPOCH OF MIDDLE AND LATE} TRIASBIC $\triangle G E$

The Lee Vining intrusive epoch is here assigned to the period of time during which granitic rocks that include the granodiorite of Mono Dome and the quartz monzonite of Lee Vining Canyon that are exposed to the east of the Tuolumne Intrusive Series in the Sierra Nevada and in the vicinity of Mono Lake were emplaced (Kistler, 1966a, 1966b). The Late Cretaceous quartz monzonite of Aeolian Buttes intrudes the quartz monzonite of Lee Vining Canyon in exposures west of Grant Lake in the June Lake Loop (Kistler, 1966a). We have also seen a porphyritic granodiorite intruded during the Lee Vining intrusive epoch that is intruded by an equigranular quartz monzonite of the Inyo Mountains intrusive epoch in Blind Spring Hill, due west of the northern end of the White Mountains.

Maximum biotite and hornblende potassium-argon ages for rocks in this series are 210 m.y. (61008, 61026) and rubidium-strontium whole-rock analyses yield an isochron of $206 \mathrm{~m}$.y. for specimens of the quartz monzonite of Lee Vining Canyon (fig. $6 D$, table 4). Biotite and hornblende ages of these Middle Triassic granitic rocks are reduced and grossly discordant in specimens collected near the Tuolumne Intrusive Series in the Sierra Nevada (DKA 1030, MKA 410); the ages are maximum and concordant in specimens from exposures south of Mono Lake $(61008,61026)$. The geochronologic data indicate the Lee Vining intrusive epoch spans the time interval from $210 \mathrm{~m} . \mathrm{y}$. to $195 \mathrm{~m} . \mathrm{y}$. ago and is Middle and Late Triassic age.

\section{SUMMARY OF AGES IN ALI INTRUBIVE EPOCHS}

The potassium-argon mineral ages and whole-rock rubidium-strontium ages that have been discussed are projected onto diagrammatic sections that show the intrusive epochs of the batholithic rocks across California (figs. 7, 8). Potassium-argon "ages" of all mineral systems from the specimens of older rock plutons may be reduced near contacts with succeeding younger intrusive bodies. In all of the older rocks, however, samples have been collected sufficiently distant from younger intrusive rocks to insure that the minerals of the older rocks have had practically complete retention of all radiogenic argon generated since their initial cooling, as shown by their concordant and older ages. Ages of biotitehornblende pairs from plutons intruded during the Cathedral Range intrusive epoch are generally concordant. Maximum concordant ages of mineral pairs in all the intrusive epochs are in close agreement with either the whole-rock rubidium-strontium age of rocks of the intrusive epoch or with uranium-lead age of zircons of the epoch. These maximum ages are taken to mark the beginning of each of the five epochs of plutonism in the 


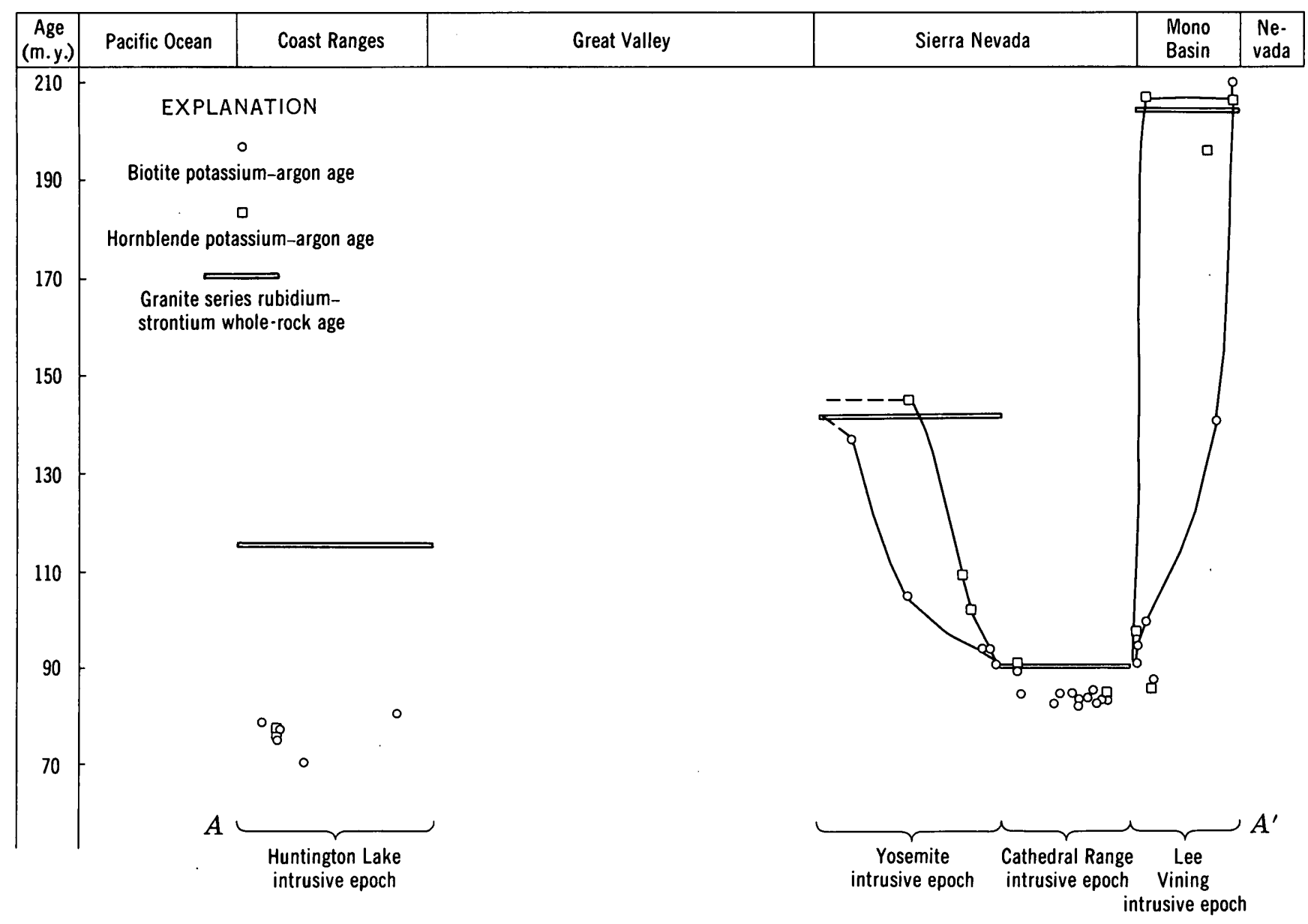

FIgURe 7.-Potassium-argon mineral ages and rubidium-strontium whole-rock ages for granitic rocks of the Iee Vining, Yosemite, Huntington Lake, and Cathedral Range intrusive epochs projected to a diagrammatic cross section of Callfornia. Location of cross section shown on plate 2.

Sierra Nevada and environs. The data on concordant biotite-hornblende ages show that the intrusive process takes 10 to 20 million years for a given epoch, thus explaining the near continuum of granite emplacement indicated by the concordant potassium-argon mineral ages.

Analysis of the entire body of potassium-argon dates of this report suggests the distribution of outcrops of rocks of the five intrusive epochs as outlined on plate 1. In some areas, an assignment of granitic rocks to a specific epoch cannot be made on the basis of existing data. This fact is especially true for batholiths of southern California and the Coast Range. The data do suggest, however, that the predominant Mesozoic granitic rocks in these areas are about 115 to 120 m.y. old but do not exclude the possibility that representatives of older and younger Mesozoic granitic rocks are present. The boundaries shown for rocks belonging to the five epochs are not to be considered the same as contacts that would be drawn on a geologic map. Detailed map- ping in the field may change any of the traces, but the gross distribution cannot vary much from that indicated.

Granite emplacement during the Paleozoic in eastern Australia (Evernden and Richards, 1962) and during the Mesozoic in the Sierra Nevada covered comparable intervals of time. Spatial patterns of intrusion in the two areas, however, were different. Successive pulses of granitic rock were emplaced in a regular way from southwest to northeast in Australia with little intrusion of an earlier series by a later one. As shown on plate 1 , vast volumes of younger granite in the Sierra Nevada now occupy terranes previously occupied by older plutons. The predominant area of Middle Triassic granites is to the east of the Sierra Nevada in the Mono Lake area. Rocks of the Early Jurassic epoch occur predominantly in the Inyo and White Mountains, but also occur in the eastern Sierra Nevada, the western foothill belt of the Sierra Nevada, and the Klamath Mountains in northern California. East of the Sierras, there is 


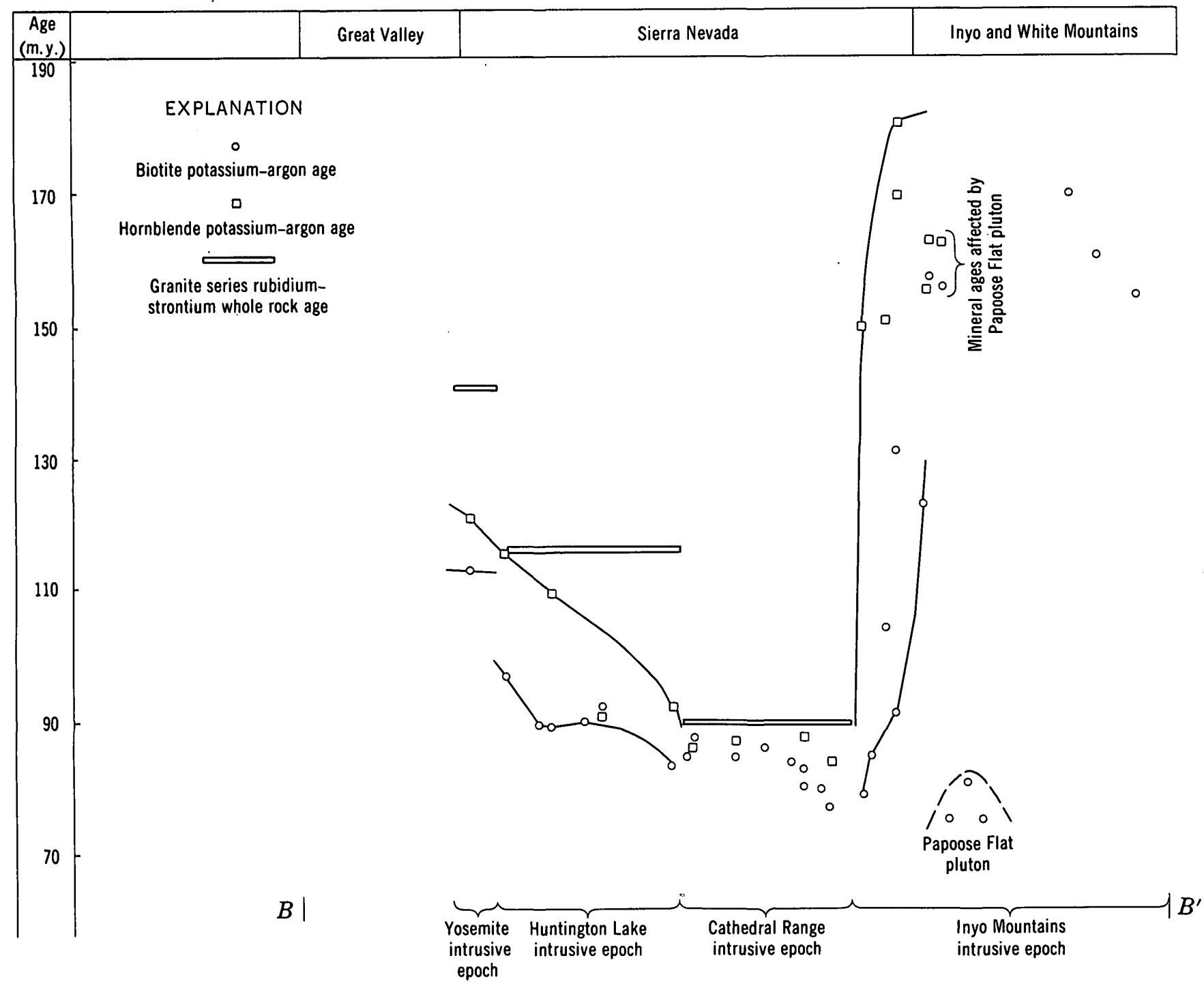

Fraure 8.-Potassium-argon mineral ages and rubidium-strontium whole-rock ages for granitic rocks of the Inyo Mountains, Yasemite, Huntington Lake, and Cathedral Range intrusive epochs projected to a diagrammatic cross section of California. Location of cross section shown on plate 2 .

not much replacement of rocks of one epoch by rocks of another; at a few places in the Inyo-White Mountain terrane, however, Late Cretaceous plutons crop out. The Mesozoic granitic rocks of southern California and those presently occurring in the Coast Ranges are predominantly of Early Cretaceous age, whereas the major mass of granites in the High Sierra are of Late Cretaceous age.

Present spatial distribution implies that rocks of all five intrusive epochs were emplaced in the region now defined by the crestal area of the Sierra Nevada from the latitude of Mono Lake southward and that massive replacement of rocks of each earlier intrusive epoch by invasion during succeeding epochs has taken place. The axis of emplacement shifted markedly in the Early and Late Cretaceous with associated replacement of the entire central portion of the Lower Jurassic batholith. It is probably significant that the deepest root of the Sierra Nevada is beneath this region.

\section{UPLIFT OF PLUTONS OF THE TRANSVERSE AND COAST RANGES}

If the age discordance shown by KA 1582 and KA 1582-HBD at the southern end of the Sierra Nevada is confirmed by additional dates, the pattern of biotite ages in that area may be interpreted as the result of uplift-as suggested by agreement of KA $1575-\mathrm{HBD}$ (88 m.y.), KA 1575 (86 m.y.), KA 1582-HBD (86 m.y.) associated with disagreement of KA 1582-HBD (86 m.y.) and KA 1582 (74 m.y.) (table 5) -the hy- 
pothesis being that the discordance is the result of erosion of these granitic rocks to great depth. The explanation of the decrease in topographic height of the mountain range south of Mount Whitney has always been a problem. An explanation based upon relative uplift would require either a flexure of the batholith or extensive faulting and downdropping of the southern end. Faulting is not supported by field data, and flexure is difficult to evaluate. A third possibility is that uplift was continuous in direction from north to south but that erosion rates were greater to the south; the postulation would be that the interplay of these two factors lead to a topographic culmination in the vicinity of Mount Whitney. Such an explanation might be indicated by a biotite-hornblende age discordance at Walker Pass, whereas an explanation based upon warping would not be substantiated by such discordance.

The potassium-argon mineral ages in the San Gabriel Mountains and in the Coast Range plutons are the youngest so far determined for Mesozoic granitic rocks in California. Biotite ages are as young as $61 \mathrm{~m}$.y. (KA 1680) and hornblende ages as young as 70 m.y. (KA 1696-HBD). Age determinations by other techniques show that these granitic plutons are significantly older than indicated by the potassium-argon determinations, but geologic mapping indicates that the reduced mineral ages for these rocks are not attributable to intrusion of adjacent younger intrusions.

Another interpretation for the reduced mineral ages in the Coast Range plutons and in the San Gabriel plutons may be that the presently exposed levels of these rocks were once buried at depths where temperatures were sufficiently high to cause loss of accumulating argon from the minerals dated. However, some of the ages of biotite-hornblende pairs are concordant. Estimates from available diffusion data indicate that a temperature of about $650^{\circ} \mathrm{C}$ is required for hornblende to lose accumulating radiogenic argon at the same rate as biotite at $325^{\circ} \mathrm{C}$. A temperature of $650^{\circ} \mathrm{C}$ would be attained at depths of approximately 20 to $26 \mathrm{~km}$, depending upon the geothermal gradient. In the Santa Lucia Mountains, biotite and hornblende ages are concordant at 77 m.y. (Campanian) and the plutons are unconformably overlain by Campanian sedimentary rocks. To have the reduced ages due solely to high temperature resulting from deep burial of the presently exposed levels of these intrusions would require an uplift of 20 or more kilometers within a single geologic epoch. Since this rate of uplift seems excessive, the reduced ages are more likely due to a combination of burial, and abnormal heating and strain prior to the exposure of the plutons.

The effects of strain and physical disruption on the minerals dated has to be considered a cause for the reduced ages in the Coast Ranges, where most of the basement rocks are sheared. However, there is evidence that strain alone cannot be the cause of argon loss from biotite and hornblende in this terrane. First, specimens of Wheeler Crest Quartz Monzonite were collected from the mylonite zone of the eastern frontal scarp of the Sierra Nevada (specimens MT-3, MT-4, Kistler and others, 1965) with the intention of dating the time of faulting. Potassium-argon ages of biotite (69 m.y., MT3 ; 79 m.y., MT-4) and of hornblende (96 m.y., MT-3; 99 m.y., MT-4) were grossly discordant in these rocks. The discordance indicated that the technique was useless for the purpose intended, that is, dating the time of faulting, but for the present discussion it is useful in indicating that strain results in discordant biotite-hornblende potassium-argon ages. The reduced potassiumargon ages are discordant in only one of the dated biotite hornblende pairs from the San Gabriel Mountains-Coast Range terrane. Second, the shearing in the Coast Range and San Gabriel Mountains basement rocks is probably due principally to Cenozoic tectonic events, but the concordant biotite-hornblende ages are all Late Cretaceous. Even though shearing of the Coast Range basement may have resulted in some loss of argon from minerals in the rocks, the two considerations made indicate that additional causes are necessary to explain the observed reduced concordant ages.

Geologic evidence indicates that the deepest crustal levels exposed in California are in the basement rocks which lie to the west of the San Andreas fault in the Coast Ranges and between the San Andreas fault and the San Gabriel fault in southern California. Metamorphic mineral assemblages of the Junipero Serra region of the Santa Lucia Range are of highest amphibolite facies and locally granulite facies (Compton, 1966). Precambrian gneisses and schists of high metamorphic grade are exposed between the San Andreas and San Gabriel faults in the San Gabriel Mountains. The Late Cretaceous mineral ages of Early Cretaceous and older Mesozoic plutons may reflect the time when these rocks were brought into crustal regions where they could cool to temperatures (about $300^{\circ} \mathrm{C}$ ) that were compatible with equal retention of radiogenic argon in biotite and hornblende.

\section{GRANITE EMPLACEMENT AND SEDIMENTATION ON THE CONTINENT}

The relation between granite emplacement in the Sierra Nevada during the Cretaceous Period and the history of sedimentation in the Sacramento-San Joaquin Valley to the west is shown in figure 9. While constructing this figure, we discovered a previously published figure of similar type by Chuber (1962). The resulting figure 9 of this paper is then a modification 


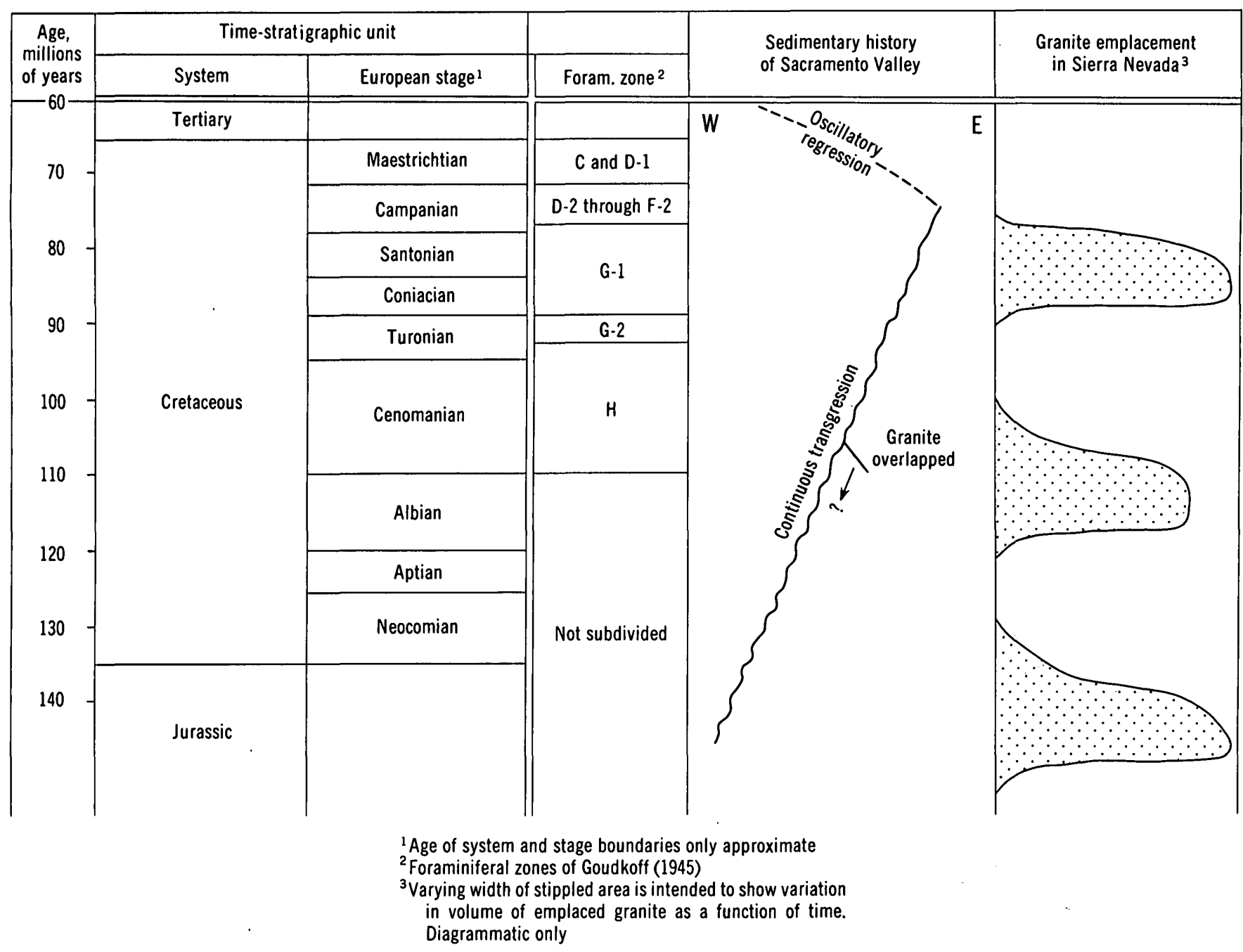

Froure 9.-Relation of sedimentation in the Sacramento Valley to granite emplacement in the Sierra Nevada area (in part a modification and extension of Chuber, 1962).

and extension of his. Note on figure 9 the extent of overlap of presumably Jurassic granites that has occurred in the Great Valley (Smith, 1964; Hoffman, 1964; Callaway, 1964). Cenomanian sedimentary rocks are known to overlap granites in the Great Valley, and only deeper drilling farther west will determine the actual extent of such granitic rocks. Also, note that eastward transgression of the Cretaceous seas was continuous from the earliest Cretaceous to the time of the E-zone of Goudkofi (Forbes Shale of Edmondson, 1962), that is, throughout the entire period of emplacement, uplift, and erosion of Cretaceous granite a few tens of miles to the east. During all of this time, most of the Cretaceous sediment came from erosion of the Sierra Nevada (Chuber, 1962). Uppermost Cretaceous sediments presently occur in the subsurface approximately 10 miles east of Merced (Callaway, 1964). Most of the biotite in the Upper Cretaceous sediments on the west side of the Great Valley was derived from Cretaceous granites of the Sierra Nevada (Curtis and others, 1958). Only subsequent to the close of final granite emplacement did eastward transgression of the Cretaceous seas cease; oscillatory regression and eventual basin filling followed.

On a larger scale, the total time span of Mesozoic intrusion in California coincides with that of the transgression of Mesozoic epicontinental seas onto North America. This correspondence is revealed by comparing the ages of California granitic rocks with data on the transgressing epicontinental seas. From paleogeographic maps representing various stages of the Mesozoic and Cenozoic (Schuchert, 1955), Damon and Mauger (1966) plotted areas of marine deposition within the present boundaries of North America as percentages of continent inundated. We have reproduced their graph in figure 10. The curve clearly shows that the Mesozoic transgressive episode, which terminated in the Turonian stage of the Late Cretaceous, when 31 percent 


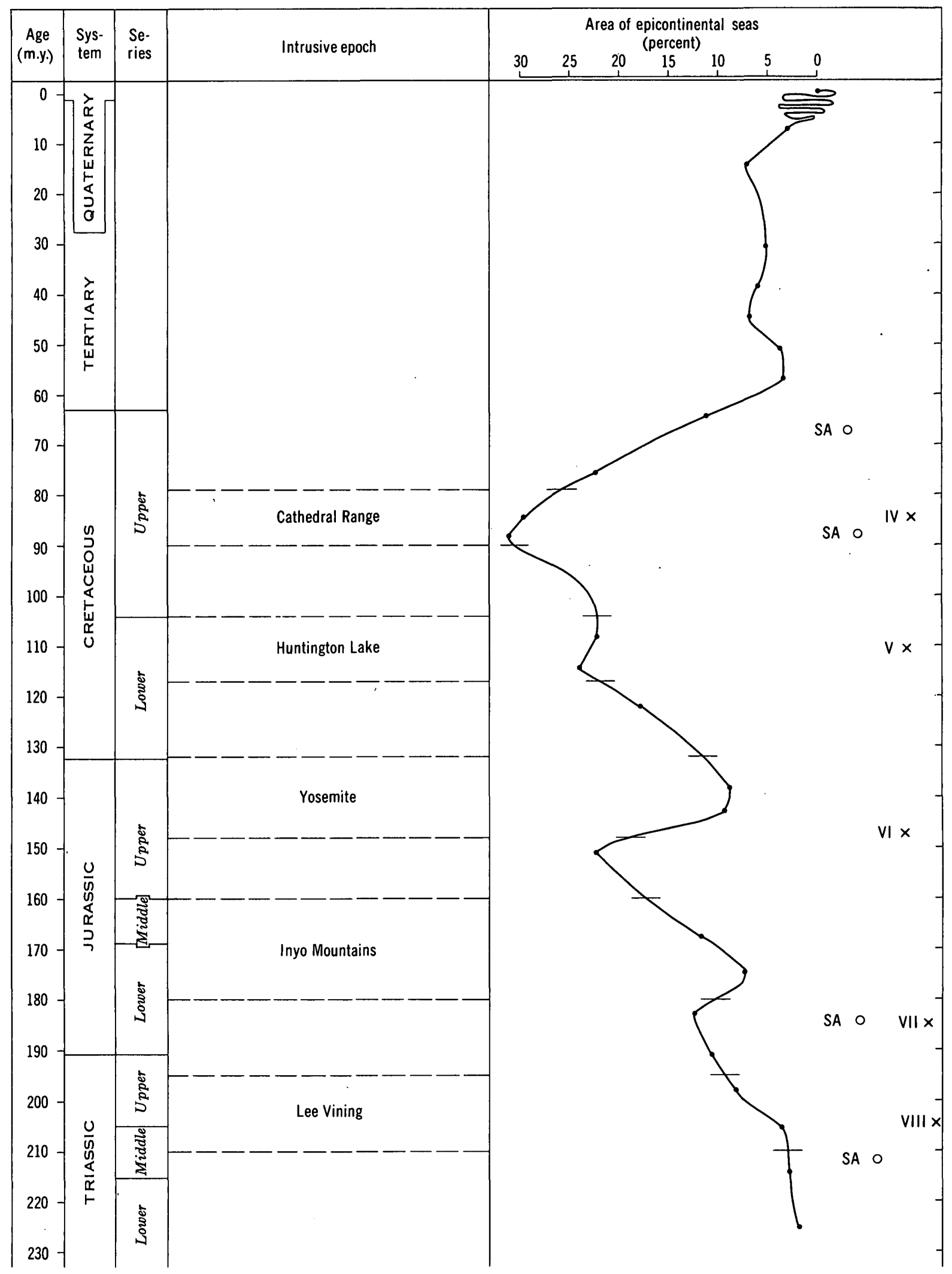

Figure 10.- (For explanation see facing page.) 
of North America was inundated, had temporary but distinct reversals.

Damon and Mauger (1966) were concerned with the relationship between magmatism and orogeny in postTuronian time. On the basis of available mica-potassium-argon ages of granitic rocks in the Great Basin, they showed two Cenozoic deformational and plutonic episodes to be coincident in time with the two reversals in the last $60 \mathrm{~m} . \mathrm{y}$. of their curve. They suggested then that transgression and regression of epicontinental seas reflected orogenic events and proposed that three other orogenies occurred within the time intervals represented by the three major withdrawals which occurred during the Mesozoic.

Our data require a refinement of this interpretation since the beginning of each Mesozoic plutonic episode is approximately coincident with a peak which marks the beginning of a temporary reversal of the general transgression curve. Also plotted in figure 10 are the intervals of time we have determined for each of the five epochs of granitic intrusion in the Mesozoic batholiths of Califormila. The remarkable correlation between the presently known periods of temporary regression of the epicontinental seas and the periods of granite emplacement is obvious.

\section{CORRESPONDENCE OF INTRUSIVE AND}

\section{DEFORMATIONAL EVENTS IN THE SIERRA NEVADA}

Immediately preceding, and in part contemporaneous with, each of the periods of voluminous magma intrusion, deformational events of regional extent occurred in California and western Nevada. The term pulse is used by us for each temporally related deformational and intrusive event. The five pulses are described as follows:

Early or Middle Triassic pulse (Lee Vining intrusive epoch).-Early or Middle Triassic deformation of regional extent in the Sierra Nevada folded layered Permian and older sedimentary and volcanic rocks in the Ritter Range pendant directly west of outcrops of granitic rocks intruded during the Lee Vining intrusive epoch (Kistler, 1966a).

Early and Middle Jurassic pulse (Inyo Mountains intrusive epoch).-Folding and thrusting that was well advanced before the end of deposition of the Early and Middle Jurassic Dunlap Formation occurred in the area immediately north of outcrops of Lower Jurassic granitic rocks of the Inyo-White Mountains batholith (Ferguson and Muller, 1949). Near its base, the Dunlap
Formation contains fassils characteristic of the upper part of the Lower Jurassic or upper Lias of the European section.

Late Jurassic pulse (Yosemite intrusive epoch).Folds in Upper Jurassic (Oxfordian and Kimmeridgian) metamorphosed sedimentary and volcanic rocks in the foothill belt of the Sierra Nevada are truncated by batholithic rocks of the Yosemite intrusive epoch. Folding and thrusting unquestionably preceded plutonic intrusion, and the two events may be considered component parts of a revolution according to Taliaferro (1942).

Early Cretaceous pulse (Huntington Lake intrusive epoch).-In the Santa Lucia Mountains of the California Coast Ranges, an unconformity between the Marmalejo Formation of Taliaferro (1944) of very early Cretaceous age, and the Jack Creek Formation of Taliaferro (1944) of early Late Cretaceous age, marks a late Early Cretaceous disturbance. In the Peninsular Ranges of California, a major unconformity occurs between marine strata of Late Cretaceous age and marine strata of Early Cretaceous and earliest Late Cretaceous ages (Jahns, 1954), the older rocks having been metamorphosed and then intruded by granitic rocks of the Huntington Lake intrusive epoch.

Late Cretaceous pulse (Cathedral Range intrusive epoch).-In the Jackson Mountains of northwestern Nevada, on line with the trend of granitic rocks of the Cathedral Range intrusive epoch exposed in the Sierra Nevada, Lower Cretaceous sedimentary rocks were folded and then eroded before deposition of the next younger rock unit of Late Cretaceous or early Tertiary age (Willden, 1958).

The record of the Cretaceous deformational events cannot be demonstrated in stratified rocks in roof pendants in most of the present physiographic Sierra Nevada (Kistler, 1966b) owing to previous intrusion of Jurassic and older granitic rocks. These granitic rocks were not susceptible to folding, as were the layered rocks folded on the flanks of the granite massifs. Local folding superimposed on Late Jurassic folds in Jurassic and Paleozoic sedimentary rocks in the foothill belt of the Sierra Nevada (Best, 1963) may be related to either of the two Cretaceous deformations.

The correlation of California tectonic and intrusive pulses with oscillations of the North American epicontinental seas implies that these pulses must have been significant throughout the entire Cordilleran region.

Curve showing extent of expicontinental seas (after Damon and Mauger, 1966) during the Cenozoic and Mesozoic Eras (time scale after Harland and others, 1964). Circles marked SA represent oldest dates of South American intrusive rock intervals; the X's marked IV-VIII represent the oldest ages of the time intervals of Gabrielse and Reesor (1964) for intrusive, rock series of British Columbia. 
Age data from Mesozoic batholithic rocks in British Columbia, Canada, suggest a similar pattern. On the basis of about 50 mica potassium-argon ages, Gabrielse and Reesor (1964) separate five Mesozoic intrusive events which they designate with numbers VIII through IV. The oldest age determined for granitic rocks in each of these episodes is plotted next to its corresponding number on our figure 10. Stratigraphic evidence was used by Gabrielse and Reesor to show unconformities coincident with periods VIII, VII, and V. They state in their concluding remarks that "There appears to be a succession of pulsatory events at about 30 million year intervals, established in part by stratigraphy, and in part by potassium-argon determinations."

Potassium-argon dates by us from Mesozoic granitic rocks in the South Americrn cordillera (Peru and Bolivia), although limited in coverage and number, indicate a similar periodic intrusive history. Of particular significance is the fact that the oldest Mesozoic batholithic rocks of this region are of Middle Triassic age (equivalent in age to the Lee Vining intrusive epoch). Other granitic rocks dated are equivalent in age to those emplaced in California during the Inyo Mountain and the Cathedral Range intrusive epochs. These data are shown on figure 10 and the locations of the samples of Middle Triassic age are given in table 5 .

\section{CONCLUSIONS}

The emplacement of Mesozoic batholithic rocks in the North American cordillera was accomplished during five major pulses of deformation and intrusion (all five were not demonstrated for South America by our limited data). In addition, the patterns of deposition, in both western California and central North America, show that these regions were being lowered progressively by epeirogenic movement during the same period of time, culminating in the Turonian stage of the Late Cretaceous, when 31 percent of the present continental area was below sea level. A new geological term should be coined for such a profound and complex series of continent-wide (or hemisphere-wide) events as oocurred in North America during this period of combined extensive foundering and massive intrusion and uplift. The term should be defined so as to stress the detailed correspondence in time of apparently secondary features of the phenomenon. It should be also stressed that, as the mass of intruded granite became greater, the inundations became greater. Only when massive emplacement of granite ceased, did emergence of the continent occur.

It is obvious that the fundamental explanation for mobilization of the magmas subsequently emplaced in eastern California cannot be found in localized downwarping of a deep sedimentary basin. Mechanisms much more profound than this must be found to explain the detailed correspondence of events here discussed. Present geological thought would probably attempt to find a driving mechanism for these events, either in complimentary phase changes or by horizontal convective transport of vast quantities of material. Both of these explanations actually depend upon an even more fundamental process, that is, a perturbation of uniform heat flow within the mantle of the earth. Both syntheses can, and probably will, be extensively developed.

\section{REFERENCES CITED}

Banks, P. O., and Silver, L. T., 1966, Evaluation of the decay constant of uranium 235 from lead isotope ratios: Jour. Geophys. Research, v. 71, no. 16, p. 4037-4046.

Bateman, P. C., 1961, Granitic formations in the east-central Sierra Nevada near Bishop, California: Geol. Soc. America Bull., v. 72, no. 10, p. 1521-1537.

Bateman, P. C., Clark, L. D., Huber, N. K., Moore, J. G., and Rinehart. C. D., 1963, The Sierra Nevada batholith-a synthesis of recent work across the central part: U.S. Geol. Survey Prof. Paper 414-D, $46 \mathrm{p}$.

Best, M. G., 1963, Petrology and structural analysis of metamorphic rocks in the southwestern Sierra Nevada foothills, California : California Univ. Pubs. Geol. Sci., v. 42, no. 3, p. 111-158.

Broderson, R. A., 1962, The petrology, structure, and age relationships, Cathedral Peak porphyritic quartz monzonite, central Sierra Nevada, California: California Univ. (Berkeley), Ph. D. thesis, $287 \mathrm{p}$.

Callaway, D. C., 1964, Distribution of uppermost Cretaceous sands in the Sacramento-northern San Joaquin Basin of California : San Joaquin Geol. Soc. Selected Papers, v. 2, p. 5-18.

Calkins, F. C., 1930, The granitic rocks of the Yosemite region, in Matthes, F. E., Geologic history of the Yosemite Valley : U.S. Geol. Survey Prof. Paper 160, p. 120-129.

Christensen, M. N., 1959, Geologic structure of the Mineral King area, California : California Univ. (Berkeley), Ph. D. thesis.

Chuber, Stewart, 1962, Late Mesozoic stratigraphy of the Sacramento Valley : San Joaquin Geol. Soc. Selected Papers, v. 1, p. 3-16.

Compton, R. R., 1966, Granitic and metamorphic rocks of the Salinian block, California Coast Ranges: California Div. Mines and Geology Bull. 190, p. 277-287.

Curtis, G. H., 1951, The geology of the Topaz Lake quadrangle and the eastern half of the Ebbetts Pass, California quadrangle: California Univ. (Berkeley), Ph. D. thesis, 316 p.

Curtis, G. H., Evernden, J. F., and Lipson, J., 1958, Age determination of some granitic rocks in California by the potassium-argon method : California Div. Mines Spec. Rept. 54, $16 \mathrm{p}$.

Damon, P. E., and Mauger, R. L., 1966, Epeirogeny-orogeny viewed from the Basin and Range province: Soc. Mining Engineer Trans., v. 235, no. 1, p. 99-112.

Davis, G. A., 1961, Metamorphic and igneous geology of preCretaceous rocks, Coffee Creek area, northern Trinity Alps, Klamath Mountains, California: California Univ. (Berkeley), Ph. D. thesis. 
Edmondson, W. F., 1962, Stratigraphic relations of Upper Cro taceous rocks in Great Valley, California : San Joaquin Geol. Soc. Selected Papers, v. 1, p. 17-26.

Ellis, A. J., and Fyfe, W. S., 1956, A note on the calcite-wollastonite equilibrium: Am. Mineralogist, v. 41, nos. 9-10, p. 805-807.

Evernden, J. F., and Curtis, G. H., 1965, The potassium-argon dating of late Cenozoic rocks in East Africa and Italy: Current Anthropology, v. 6, p. 343-385.

Evernden, J. F., Curtis, G. H., Kistler, R. W., and Obradovich, J. D., 1960, Argon diffusion in glauconite, microcline, sanidine, leucite, and phlogopite: Am. Jour. Sci., v. 258, no. 8, p. 583-604.

Evernden, J. F., and James, G. T., 1964, Potassium-argon dates and the Tertiary floras of North America: Am. Jour. Sci., v. 262 , no. 8 , p. $945-974$.

Evernden, J. F., and Richards, J. R., 1962, Potassium-argon ages in eastern Australia : Geol. Soc. Australia Jour., v. 9, pt. 1, p. $1-50$.

Evernden, J. F., Savage, D. E., Curtis, G. H., and James, G. T., 1964, Potassium-argon dates and the Cenozoic mammalian chronology of North America: Am. Jour. Sci., v. 262, no. 2, p. 145-198.

Ferguson, H. G., and Muller, S. W, 1949, Structural geology of the Hawthorne and Tonopah quadrangles, Nevada.: U.S. Geol. Survey Prof. Paper 216, 55 p.

Fyfe, W. S., Turner, F. J., and Verhoogen, John, 1958, Metamorphic reactions and metamorphic facies: Geol. Soc. America Mem. 73, $259 \mathrm{p}$.

Gabrielse, H., and Reesor, J. E., 1964, Geochronology of plutonic rocks in two areas of the Canadian Cordillera, in Osborne, F. F., ed., Geochronology in Canada: Royal Soc. Canada Spec. Pub. 8, p. 96-128.

Goudkoff, P. P., 1945, Stratigraphic relations of Upper Cretaceous in Great Valley, California: Am. Assoc. Petroleum Geologists Bull., v. 29, no. 7, p. 956-1007.

Gromme, C. S., 1963, Remanent magnetization of igneous rocks from the Franciscan and Lovejoy Formations, northern California : Oalifornia Univ. (Berkeley), Ph. D. thesis, 226 p.

Hall, W. E., and MacKevett, E. M., Jr., 1962, Geology and ore deposits of the Darwin quadrangle, Inyo County, California : U.S. Geol. Survey Prof. Paper 368, 87 p.

Hamilton, W. B., 1956, Geology of the Huntington Lake area, Fresno County, California: California Div. Mines Spec. Rept. 46, 25 p.

Harland, W. B., Smith, A. C., and Wilcock, Bruce, eds., 1964, The Phanerozolc time-scale-A symposium dedicated to Professor Arthur Holmes: Geol. Soc. London Quart. Jour., Supp., v. 120 s, $458 \mathrm{p}$.

Hart, S. R., 1964, The petrology and isotopic-mineral age relations of a contact zone in the Front Range, Colorado: Jour. Geology, v. 72, no. 5, p. 493-525.

Hay, E. A., 1963, Age and relationship of the Gold Hill Pluton, Cholame Valley, California, in Am. Assoc. Petraleum Geologists Soc. Econ. Paleontologists and Mineralogists, Paciflc Section, Guidebook to the geology of Salinas Valley and the San Andreas fault : p. 113-115.

Hoffman, R. D., 1964, Geology of the northern San Joaquin Valley [Ca,lifornia]: San Joaquin Geol. Soc. Selected Papers, v. 2, p. $30-45$.

Holdaway, M. J., 1963, Petrology und structure of metamorphic and Igneous rocks of parts of northern Coffee Creek and Cecilville quadrangle, Klamath Mountains, California : California Univ. (Berkeley), Ph. D. thesis, 202 p.
Holm, J. L., and Kleppa, O. J., 1966, The thermodynamic properties of the aluminum silicates: Am. Mineralogist, v. 51, nos. 11-12, p. 1608-1622.

Hurley, P. M., Bateman, P. C., Fairbairn, H. W., and Pinson, W. E., Jr., 1965, Investigation of the Initial $\mathrm{Sr}^{87} / \mathrm{Sr}^{89}$ ratios in the Sierra Nevada plutonic province: Geol. Soc. America Bull., v. 76, no. 2, p. 165-174.

Jaffe, H. W., Gottfried, David, Waring, C. L., and Worthing, H. W., 1959, Lead-alpha age determinations of accessory minerals of igneous rocks (1953-1957) : U.S. Geol. Survey Bull. 1097-B p. 65-148.

Jahns, R. H., 1954, Geology of the Peninsular Range province, southern California and Baja California [Mexico]: [pt.] 3 in Chap. 2 of Jahns, R. H., ed., Geology of southern California: California Div. Mines and Geology Bull. 170, p. 29-52.

Jenkins, S. F., 1961, A structural study of a portion of the Kernville Series (?Jurassic ; California): California Univ. (Berkeley), M.A. thesis.

Kistler, R. W., 1966a, Geologic map of the Mono Craters quadrangle, Mono and Tuolumne Counties, California : U.S. Geol. Survey Geol. Quad. Map GQ-462, scale 1: 62,500.

1966b, Structure and metamorphism in the Mono Craters Quadrangle Sierra Nevada, California : U.S. Geol. Survey Bull. 1221-E, 53 p.

-1968, Potassium-argon ages of volcanic rocks in Nye and Esmeralda Counties, Nevada : Geol. Sec. America Mem. 110. p. 251-262.

Kistler, R. W., Bateman, P. C., and Brannock, W. W., 1965, Isotopic ages of minerals from granitic rocks of the central Sierra Nevada and Inyo Mountains, California: Geol. Soc. America Bull., v. 76, no. 2, p. 155-164.

Kistler, R. W., and Dodge, F. C. W., 1966, Potassium-argon ages of coexisting minerals from pyroxene-bearing granitic rocks in the Sierra Nevada, California: Jour. Geophys. Research, v. 71, no. 8, p. $2157-2161$.

Krauskopf, K. B., 1953, Tungsten deposits of Madera, Fresno, and Tulare Counties, California : California Div. Mines Spec. Rept. 35, $83 \mathrm{p}$.

Larsen, E. S., Jr., 1948, Batholith and associated rocks of Corona, Elsinore, and San Luis Rey quadrangle, southern California : Geol. Soc. America Mem. 29, 182 p.

Macdonald, G. A., 1941, Geology of the western Sierra Nevada between the Kings and San Joaquin River, California: California Univ. Pubs. Geol. Sci., v. 26, no. 2, 215-286.

Mayo, E. B., 1941, Deformation in the interval Mt. Lyell-Mt. Whitney, California: Geol. Soc. America Bull., v. 52, no. 7, p. 1001-1084.

McKee, E. H., 1962, The stratigraphy and structure of a portion of the Magruder Mountain-Soldier Pass quadrangles, California-Nevada : California Univ. (Berkeley), Ph. D. thesis. $108 \mathrm{p}$.

McKee, E. H., and Nash, D. B., 1967, Potassium-argon ages of granitic rocks in the Inyo Batholith, east-central California : Geol. Soc. America Bull., v. 78, p. 669-680.

McKee, E. H., and Nelson, C. A., 1967, Geologic map of the Soldier Pass quadrangle, California and Nevada: U.S. Geol. Survey Geol. Quad. Map GQ-654, scale $1: 62,500$.

[Miller, W. J., 1931, Geologic sections across the southern Sierra Nevada of California: California Univ. Pubs. Geol. Sci., v. 20 , no. 9 , p. $331-360$.

Miller, W. J., and Webb, R. W., 1940, Descriptive geology of the Kernville quadrangle, California: California Jour. Mines and Geology, v. 36, no. 4, p. 343-378. 
Parker, R. B., 1961, Petrology and structural geometry of pregranitic rocks in the Sierra Nevada, Alpine County, California : Geol. Soc. America Bull., v. 72, no. 12, p. 1789-1806.

Rama, S. N. I., Hart, S. R., and Roedder, E., 1965, Excess radiogenic argon in fluid inclusions : Jour. Geophys. Research, v. 70, p. 509-511.

Romey, W. D., 1962, Geology of a part of the Etna quadrangle, Siskiyou County, California : California Univ. (Berkeley), Ph. D. thesis.

[Ross, D. C., 1965, Geology of the Independence quadrangle, Inyo County, California: U.S. Geol. Survey Bull. 1181-0, 64 p.

Schuchert, Charles, 1955, Atlas of paleogeographic maps of North America : New York, John Wiley \& Sons, Inc.

Sherlock, D. G., and Hamilton, W. B., 1958, Geology of the north half of the Mount Abbot quadrangle, Sierra Neradia, California : Geol. Soc. America Bull., v. 69, no. 10, p. 1245-1267.
Slemmons, D. B., 1953, Geology of the Sonora Pass Region: California Univ. (Berkeley), Ph. D. thesis, $201 \mathrm{p}$.

Smith, M. B., 1964, Map showing distribution and configuration of basement rocks in California : U.S. Geol. Survey Oil and Gas Inv. Map OM-215, scale 1:500,000.

Taliaferro, N. L., 1942, Geologic history and correlation of the Jurassic of southwestern Oregon and California : Geol. Soc. America Bull., v. 53, no. 1, p. 71-112.

1944, Cretaceous and Paleocene of Santa Lucia Range, California : Am. Assoc. Petroleum Geologists Bull., v. 28, no. 4, p. 449-521.

Weill, D. F., 1966, Stability relations in the $\mathrm{Al}_{2} \mathrm{O}_{3}-\mathrm{SiO}_{3}$ system calculated from solubilities in the $\mathrm{Al}_{2} \mathrm{O}_{3}-\mathrm{SiO}_{2}-\mathrm{Na}_{3} \mathrm{AlF}_{6}$ system : Geochim. et Cosmochim. Acta, v. 30, no. 2, p. 223-237.

Willden, C. R., 1958, Cretaceous and Tertiary orogeny in Jackson Mountains, Humboldt County, Nevada: Am. Assoc. Petroleum Geologists Bull., v. 42, no. 10, p. 2378-2398. 
TABLES 5 and 6 
TABLE 5

TABLE 5.-Potassium-argon analyses and location of sample localities

[The following ages (also shown on pl. 2) for the location numbers given were taken from previously published data: 155-166 (Curtis and others, 1958); 167-168 (Kistler and

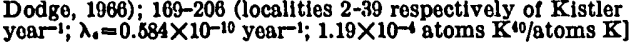

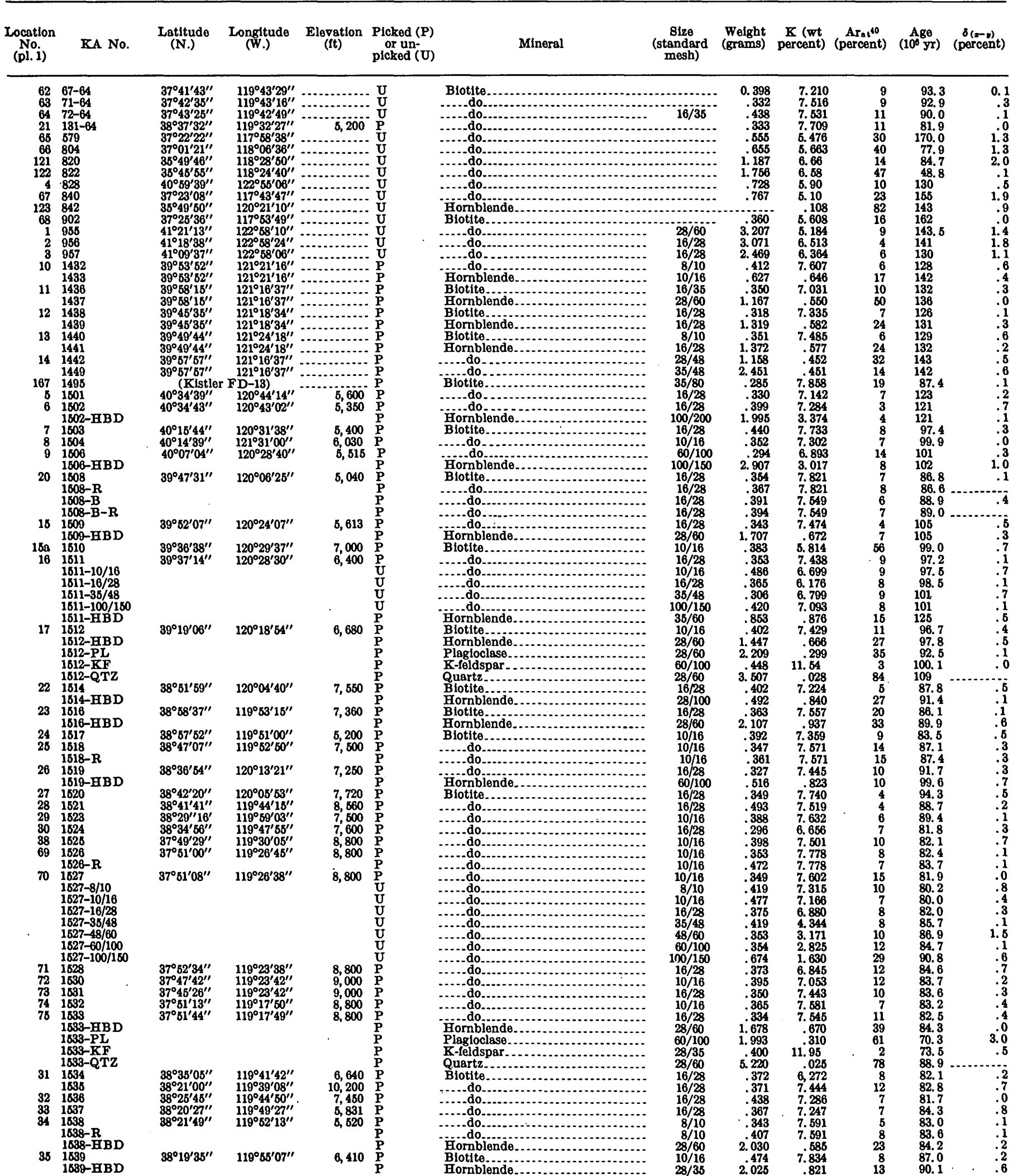


TABLE 5.-Potassium-argon analyses and location of sample localities-Continued

\begin{tabular}{|c|c|c|c|c|c|c|c|c|c|c|c|c|}
\hline $\begin{array}{c}\text { Location } \\
\text { No. } \\
\text { (pl. 1) }\end{array}$ & KA No. & $\begin{array}{l}\text { Latitude } \\
\text { (N.) }\end{array}$ & $\begin{array}{l}\text { Longitude } \\
\text { (W.) }\end{array}$ & $\begin{array}{c}\text { Elevation } \\
\text { (ft) }\end{array}$ & $\begin{array}{l}\text { Picked (P) } \\
\text { or un- } \\
\text { picked (U) }\end{array}$ & Mineral & $\begin{array}{c}\text { Size } \\
\text { (standard } \\
\text { mesh) }\end{array}$ & $\begin{array}{c}\text { Weight } \\
\text { (grams) }\end{array}$ & $\underset{\text { percent) }}{\mathrm{K}(\mathrm{wt}}$ & $\underset{\text { (percent) }}{\mathbf{A r}_{a a^{40}}}$ & $\underset{\left(10^{\circ} \mathrm{yr}\right)}{\mathrm{Age}}$ & $\begin{array}{c}\delta(x-y) \\
\text { (percent) }\end{array}$ \\
\hline 36 & 1540 & $38^{\circ} 17^{\prime} 05^{\prime \prime}$ & $119^{\circ} 57^{\prime} 56^{\prime \prime}$ & 6,080 & $\mathbf{P}$ & Biotite.. & $10 / 16$ & .352 & 7.767 & 7 & 88.7 & .0 \\
\hline & 1540-HBD & & & & $\mathbf{P}$ & Hornblend & $60 / 100$ & 1.980 & .839 & 33 & 96.7 & .6 \\
\hline 37 & 1541 & $38^{\circ} 11^{\prime} 59^{\prime \prime}$ & $120^{\circ} 00^{\prime} 07^{\prime \prime}$ & 5,250 & $\mathbf{P}$ & Biotite.... & $10 / 16$ & .349 & 7.705 & 6 & 94.4 & .7 \\
\hline & 1541-R & & & & $\stackrel{\mathbf{P}}{\mathbf{P}}$ & Hornblende & $\begin{array}{l}10 / 16 \\
28 / 60\end{array}$ & $\begin{array}{r}.335 \\
2309\end{array}$ & $\begin{array}{l}7.705 \\
736\end{array}$ & 7 & 94.0 & .7 \\
\hline & 1541-PL & & & & $\stackrel{\mathbf{F}}{\mathbf{P}}$ & $\begin{array}{l}\text { Horndienae } \\
\text { Plagioclase. }\end{array}$ & $\begin{array}{l}28 / 60 \\
28 / 60\end{array}$ & $\begin{array}{l}2.309 \\
1.926\end{array}$ & $\begin{array}{l}.736 \\
.233\end{array}$ & $\begin{array}{l}14 \\
42\end{array}$ & $\begin{array}{l}97.8 \\
90.7\end{array}$ & .9 \\
\hline & 1541-KF & & & & p & $\mathbf{K}$-feldspar & $28 / 35$ & $\begin{array}{r}1.920 \\
.405\end{array}$ & 12.25 & 3 & 83.5 & .5 \\
\hline & 1541-QTZ & & & & $\stackrel{P}{P}$ & Quartz & $28 / 60$ & $\begin{array}{r}2.776 \\
.787\end{array}$ & $\begin{array}{r}.019 \\
7713\end{array}$ & 92 & 108 & \\
\hline $\begin{array}{l}38 \\
39\end{array}$ & $\begin{array}{l}1542 \\
1543\end{array}$ & $\begin{array}{l}38^{\circ} 22^{\prime} 51^{\prime \prime} \\
38^{\circ} 22^{\prime} 54^{\prime \prime}\end{array}$ & $\begin{array}{l}119^{\circ} 52^{\prime} 14^{\prime \prime} \\
119^{\circ} 52^{\prime} 07^{\prime \prime}\end{array}$ & $\begin{array}{l}7,650 \\
7,600\end{array}$ & $\stackrel{P}{\mathrm{P}}$ & Biotite... & $\begin{array}{l}10 / 16 \\
10 / 16\end{array}$ & $\begin{array}{l}.487 \\
.315\end{array}$ & $\begin{array}{l}7.713 \\
7.676\end{array}$ & $\begin{array}{l}7 \\
6\end{array}$ & $\begin{array}{l}84.8 \\
82.9\end{array}$ & .5 \\
\hline & 1545 & $38^{\circ} 17^{\prime} 19^{\prime \prime}$ & $119^{\circ} 43^{\prime} 06^{\prime \prime}$ & 7,360 & $\mathrm{P}$ & do............ & $16 / 28$ & .340 & 7.369 & 8 & 82.7 & .4 \\
\hline 40 & 1546 & $38^{\circ} 24^{\prime} 58^{\prime \prime}$ & $119^{\circ} 50^{\prime} 00^{\prime \prime}$ & 7,560 & $\mathrm{P}$ & do... & $8 / 10$ & .349 & 7. 330 & 5 & 84.2 & 3 \\
\hline 41 & 1547 & $38^{\circ} 25^{\prime} 05^{\prime \prime}$ & $119^{\circ} 49^{\prime} 47^{\prime \prime}$ & 7,400 & $\underset{\mathbf{P}}{\mathbf{P}}$ & ..... do...... & $10 / 16$ & .370 & 7. 347 & 4 & 85.6 & .4 \\
\hline & $\begin{array}{l}1548 \\
1548-R\end{array}$ & $38^{\circ} 26^{\prime} 45^{\prime \prime}$ & $119^{\circ} 40^{\prime} 12^{\prime \prime}$ & 7,600 & $\stackrel{P}{P}$ & -....do.............. & $\begin{array}{l}35 / 48 \\
35 / 48\end{array}$ & $\begin{array}{l}.213 \\
.182\end{array}$ & $\begin{array}{l}6.994 \\
6.994\end{array}$ & $\begin{array}{l}9 \\
6\end{array}$ & $\begin{array}{l}81.5 \\
81.8\end{array}$ & .1 \\
\hline 43 & 1549 & $38^{\circ} 25^{\prime} 31^{\prime \prime}$ & $119^{\circ} 42^{\prime} 17^{\prime \prime}$ & 7,500 & $\mathrm{P}$ & ....do-do...... & $16 / 28$ & .453 & 7.102 & 8 & 81.1 & .2 \\
\hline 44 & 1550 & $\begin{array}{l}38^{\circ} 23^{\prime} 56^{\prime \prime} \\
37^{\circ} 27^{\prime} 15^{\prime \prime}\end{array}$ & $119^{\circ} 36^{\prime} 26^{\prime \prime}$ & 10,040 & $\stackrel{P}{\mathrm{P}}$ & . do & $16 / 28$ & .342 & 6. 682 & 9 & 79.5 & .2 \\
\hline $\begin{array}{l}76 \\
77\end{array}$ & $\begin{array}{l}1551 \\
1552\end{array}$ & $37^{\circ} 26^{\prime} 06^{\prime \prime}$ & $118^{\circ} 50^{\prime} 06^{\prime \prime}$ & $\begin{array}{r}11,500 \\
9,000\end{array}$ & $\stackrel{P}{P}$ & 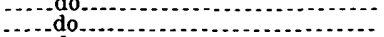 & $\begin{array}{l}16 / 28 \\
16 / 28\end{array}$ & $\begin{array}{l}.431 \\
.397\end{array}$ & $\begin{array}{l}7.009 \\
6.792\end{array}$ & $\begin{array}{r}6 \\
10\end{array}$ & $\begin{array}{l}79.1 \\
78.1\end{array}$ & .2 \\
\hline 78 & 1553 & $37^{\circ} 25^{\prime} 08^{\prime \prime}$ & $118^{\circ} 46^{\prime} 04^{\prime \prime}$ & 11,500 & $\mathrm{P}$ & do & $10 / 16$ & .464 & 7. 142 & 15 & 78.8 & .0 \\
\hline & 1553-HBD & & & & $\mathrm{P}$ & Hornblen & $60 / 100$ & .800 & .719 & 42 & 77.4 & .4 \\
\hline 79 & 1554 & $\begin{array}{l}37^{\circ} 02^{\prime} 38^{\prime \prime} \\
37^{\circ} 03^{\prime} 11^{\prime \prime}\end{array}$ & $\begin{array}{l}118^{\circ} 31^{\prime} 41^{\prime \prime} \\
118^{\circ} 34^{\prime} 46^{\prime \prime}\end{array}$ & $\begin{array}{r}11,500 \\
8,080\end{array}$ & $\stackrel{\mathrm{P}}{\mathrm{P}}$ & Biotite... & $16 / 28$ & .328 & 7.212 & 7 & 80.1 & .1 \\
\hline $\begin{array}{l}80 \\
94\end{array}$ & $\begin{array}{l}1555 \\
1556\end{array}$ & $36^{\circ} 46^{\prime} 27^{\prime \prime}$ & $\begin{array}{l}1188^{\circ} 44^{\prime \prime \prime} \\
118^{\circ} 22^{\prime} 50^{\prime \prime}\end{array}$ & $\begin{array}{r}8,080 \\
11,500\end{array}$ & $\stackrel{\mathbf{P}}{\mathbf{P}}$ & .....do do & $\begin{array}{l}16 / 28 \\
16 / 28\end{array}$ & $\begin{array}{l}.379 \\
.368\end{array}$ & $\begin{array}{l}7.067 \\
7.451\end{array}$ & $\begin{array}{r}8 \\
11\end{array}$ & $\begin{array}{l}80.1 \\
82.1\end{array}$ & .3 \\
\hline 81 & 1559 & $37^{\circ} 39^{\prime} 15^{\prime \prime}$ & $119^{\circ} 05^{\prime} 27^{\prime \prime}$ & 9,247 & $\mathbf{P}$ & ...do-do & $16 / 28$ & .354 & 7.621 & 12 & 78.7 & 1 \\
\hline 82 & 1560 & $\begin{array}{l}37^{\circ} 39^{\prime} 10^{\prime \prime} \\
37^{\circ} 20^{\prime} 27^{\prime \prime}\end{array}$ & $\begin{array}{l}119^{\circ} 05^{\prime} 27^{\prime \prime} \\
118^{\circ} 45^{\prime} 58^{\prime \prime}\end{array}$ & $\begin{array}{r}9,000 \\
11,500\end{array}$ & $\underset{\mathrm{P}}{\mathbf{P}}$ & .....do-............ & $28 / 35$ & .377 & 7.973 & 12 & 77.4 & .4 \\
\hline $\begin{array}{r}83 \\
126\end{array}$ & $\begin{array}{l}1561 \\
1562\end{array}$ & $35^{\circ} 43^{\prime} 58^{\prime \prime}$ & $118^{\circ} 23^{\prime} 28^{\prime \prime}$ & $\begin{array}{r}11,000 \\
2,800\end{array}$ & $\stackrel{p}{P}$ & , do & $\begin{array}{l}16 / 28 \\
16 / 28\end{array}$ & $\begin{array}{l}.335 \\
.366\end{array}$ & $\begin{array}{l}6.845 \\
7.177\end{array}$ & $\begin{array}{l}8 \\
8\end{array}$ & $\begin{array}{l}79.6 \\
86.6\end{array}$ & $\begin{array}{l}.8 \\
.0\end{array}$ \\
\hline 127 & $\begin{array}{l}1563 \\
1564\end{array}$ & $\begin{array}{l}35^{\circ} 59^{\prime} 13^{\prime \prime} \\
36^{\circ} 03^{\prime} 15^{\prime \prime}\end{array}$ & $\begin{array}{l}118^{\circ} 29^{\prime} 47^{\prime \prime} \\
118^{\circ} 32^{\prime} 23^{\prime \prime}\end{array}$ & $\begin{array}{l}4,000 \\
6,200\end{array}$ & $\stackrel{\mathrm{P}}{\mathrm{P}}$ & do & $\begin{array}{l}28 / 35 \\
10 / 16\end{array}$ & $\begin{array}{r}387 \\
349\end{array}$ & $\begin{array}{l}7.486 \\
7.528\end{array}$ & $\begin{array}{r}7 \\
16\end{array}$ & $\begin{array}{l}89.7 \\
88.5\end{array}$ & 1 \\
\hline & 1564-HBD & & & & $\stackrel{p}{\mathbf{P}}$ & Hornblende & $\begin{array}{l}10 / 10 \\
28 / 60\end{array}$ & $\begin{array}{l}.349 \\
1.916\end{array}$ & $\begin{array}{l}1.528 \\
1.070\end{array}$ & $\begin{array}{l}10 \\
11\end{array}$ & $\begin{array}{l}88.0 \\
95.6\end{array}$ & .2 \\
\hline & $\begin{array}{l}\text { 1564-PL } \\
1564-\mathrm{KF}\end{array}$ & & & & $\stackrel{P}{\mathrm{P}}$ & $\begin{array}{l}\text { Plagioclase.... } \\
\text { K-feldspar. }\end{array}$ & $\begin{array}{l}28 / 60 \\
35 / 48\end{array}$ & $\begin{array}{r}2.154 \\
.495\end{array}$ & $\begin{array}{r}.277 \\
11.69\end{array}$ & $\begin{array}{r}49 \\
2\end{array}$ & $\begin{array}{l}72.6 \\
87.5\end{array}$ & $\begin{array}{l}.8 \\
.3\end{array}$ \\
\hline & $1564-\mathrm{QTZ}$ & & & & $\mathrm{P}$ & Quartz & $28 / 60$ & 3. 323 & .014 & 92 & 57.9 & \\
\hline 96 & 1565 & $36^{\circ} 07^{\prime} 33^{\prime \prime}$ & $118^{\circ} 33^{\prime} 22^{\prime \prime}$ & 6,730 & $\mathbf{P}$ & Biotite.. & $16 / 28$ & .351 & 7.472 & 6 & 87.5 & 3 \\
\hline 97 & $\begin{array}{l}1566 \\
1566-\mathrm{R}\end{array}$ & $36^{\circ} 09^{\prime} 03^{\prime \prime}$ & $118^{\circ} 34^{\prime} 57^{\prime \prime}$ & 5,800 & $\stackrel{P}{\mathrm{P}}$ & ....do..... & $\begin{array}{l}16 / 28 \\
16 / 28\end{array}$ & $\begin{array}{l}.317 \\
.354\end{array}$ & $\begin{array}{l}7.618 \\
7.618\end{array}$ & $\begin{array}{r}9 \\
10\end{array}$ & $\begin{array}{l}87.8 \\
88.2\end{array}$ & $\begin{array}{l}.0 \\
.0\end{array}$ \\
\hline & $1566-\mathrm{B}$ & & & & $\mathrm{P}$ & ...do..... & $16 / 28$ & .309 & 7.548 & 7 & 88.7 & .5 \\
\hline & $1566-B-R$ & & & & $\mathbf{P}$ & ....do. & $16 / 28$ & .371 & 7.548 & $\dot{9}$ & 88.2 & \\
\hline 98 & 1568 & $36^{\circ} 09^{\prime} 12^{\prime \prime}$ & $118^{\circ} 14^{\prime} 39^{\prime \prime}$ & 2,000 & $\mathrm{P}$ & ...do & $16 / 28$ & .388 & 7.522 & 7 & 91.5 & .0 \\
\hline 194 & $1568-\mathrm{HBD}$ & $35^{\circ} 44^{\prime} 36^{\prime \prime}$ & $118^{\circ} 5 A^{\prime} 12^{\prime \prime \prime}$ & 1,100 & $\underset{\mathbf{P}}{\mathbf{P}}$ & Hornblend & $16 / 28$ & 1. 033 & .877 & 17 & 96.3 & .5 \\
\hline 124 & $\begin{array}{l}1569 \\
1569-\mathrm{HBD}\end{array}$ & $35^{\circ} 44^{\prime} 36^{\prime \prime}$ & $118^{\circ} 54^{\prime} 12^{\prime \prime}$ & 1,100 & $\stackrel{P}{\mathbf{P}}$ & $\begin{array}{l}\text { Biotite.... } \\
\text { Hornblende }\end{array}$ & $\begin{array}{l}10 / 16 \\
28 / 60\end{array}$ & $\begin{array}{r}.353 \\
1.714\end{array}$ & $\begin{array}{r}7.971 \\
.590\end{array}$ & $\begin{array}{r}5 \\
24\end{array}$ & $\begin{array}{l}102 \\
108\end{array}$ & $: 13$ \\
\hline & 1569-PL & & & & $\mathrm{P}$ & Plagioclas & $60 / 100$ & $\begin{array}{l}1.714 \\
2.015\end{array}$ & .590 & $\begin{array}{l}24 \\
20\end{array}$ & $\begin{array}{l}108 \\
102\end{array}$ & 2.0 \\
\hline & $1569-\mathrm{KF}$ & & & & $\mathbf{P}$ & K-feldspar & $28 / 60$ & .265 & 9.253 & 6 & 100 & .5 \\
\hline & 1569-QTZ & & & & $\mathbf{P}$ & Quartz_... & $28 / 60$ & 2.619 & .041 & 91 & 58 & \\
\hline 125 & 1570 & $35^{\circ} 42^{\prime} 57^{\prime \prime}$ & $118^{\circ} 48^{\prime} 58^{\prime \prime}$ & 1,925 & $\mathbf{P}$ & Biotite... & $8 / 10$ & .427 & 7.829 & 9 & 98.0 & .1 \\
\hline & 1570-HBD & (20) & & & $\mathbf{P}$ & Hornblende & $28 / 60$ & 1.948 & .493 & 18 & 102 & .7 \\
\hline 128 & 1571 & $35^{\circ} 42^{\prime} 21^{\prime \prime}$ & $118^{\circ} 45^{\prime} 06^{\prime \prime}$ & 3,200 & $\mathbf{P}$ & Biotite... & $16 / 28$ & .348 & 7. 527 & 10 & 98.2 & .5 \\
\hline 129 & 1572 & $35^{\circ} 44^{\prime} 17^{\prime \prime}$ & $118^{\circ} 38^{\prime} 56^{\prime \prime}$ & 4,000 & $\mathbf{P}$ & .....do... & $10 / 16$ & .362 & 7. 556 & 10 & 92.3 & .0 \\
\hline 130 & 1573 & $35^{\circ} 44^{\prime} 51^{\prime \prime}$ & $118^{\circ} 35^{\prime} 14^{\prime \prime}$ & 4,875 & $\overline{\mathbf{P}}$ & . & $16 / 28$ & .332 & 7. 657 & 11 & 90.6 & 1 \\
\hline 131 & 1574 & $35^{\circ} 44^{\prime} 00^{\prime \prime}$ & $118^{\circ} 32^{\prime} 52^{\prime \prime}$ & 5,780 & $\mathbf{P}$ & .....do & $16 / 28$ & .356 & 7. 273 & 10 & 87.7 & .1 \\
\hline 132 & 1575 & $35^{\circ} 41^{\prime} 38^{\prime \prime}$ & $118^{\circ} 29^{\prime} 51^{\prime \prime}$ & 3,750 & $\mathbf{P}$ & $-{ }_{-}$do & $16 / 28$ & .360 & 7.127 & 15 & 85.5 & .0 \\
\hline & 1575-HBD & $9=0900$ & & & & Hornblend & $28 / 60$ & 1. 364 & i. 066 & 12 & 87.7 & .6 \\
\hline 133 & 1576 & $35^{\circ} 39^{\prime} 24^{\prime \prime}$ & $118^{\circ} 29^{\prime} 06^{\prime \prime}$ & 2,700 & $\mathbf{P}$ & Biotite & $16 / 28$ & .403 & 7.392 & 9 & 87.0 & .3 \\
\hline 134 & 1577 & $35^{\circ} 39^{\prime} 05^{\prime \prime}$ & $118^{\circ} 24^{\prime} 54^{\prime \prime}$ & 2,850 & $P$ & - . . do do... & $16 / 28$ & .339 & 7.042 & 13 & 85.1 & .3 \\
\hline 135 & 1578 & $35^{\circ} 39^{\prime} 24^{\prime \prime}$ & $118^{\circ} 19^{\prime} 17^{\prime \prime}$ & 2,625 & $\underline{\mathbf{p}}$ & .....do... & $10 / 16$ & .36 & 7. 692 & 10 & 79.2 & .2 \\
\hline 136 & 1579 & $35^{\circ} 41^{\prime} 48^{\prime \prime}$ & $118^{\circ} 12^{\prime} 50^{\prime \prime}$ & 2,800 & $\mathrm{P}$ & .....do & $35 / 48$ & .389 & 7. 335 & 9 & 78.7 & .4 \\
\hline 137 & 1580 & $35^{\circ} \mathbf{4} 3^{\prime} 46^{\prime \prime}$ & $118^{\circ} 10^{\prime} 00^{\prime \prime}$ & 2,900 & $\mathbf{P}$ & .....do... & $48 / 60$ & .277 & 7. 393 & 13 & 78.2 & .6 \\
\hline 138 & 1581 & $35^{\circ} 45^{\prime} 01^{\prime \prime}$ & $118^{\circ} 06^{\prime} 19^{\prime \prime}$ & 3,450 & $\mathbf{P}$ & ................ & $35 / 48$ & .390 & 6.884 & 20 & 66.1 & .4 \\
\hline & 1582 HBD & $35^{\circ} 41^{\prime} 45^{\prime \prime}$ & $118^{\circ} 03^{\prime} 18^{\prime \prime}$ & 4,410 & $\mathbf{P}$ & . do & $16 / 28$ & .385 & 7. 620 & 21 & 74.0 & $.0^{\circ}$ \\
\hline & $\begin{array}{l}1582-\mathrm{HBD} \\
1583\end{array}$ & $36^{\circ} 35^{\prime} 44^{\prime \prime}$ & $118^{\circ} 06^{\prime} 10^{\prime \prime}$ & 4,370 & $\stackrel{\mathbf{P}}{\mathbf{P}}$ & $\begin{array}{l}\text { Hornblende_... } \\
\text { Biotite }\end{array}$ & $\begin{array}{l}16 / 28 \\
10 / 16\end{array}$ & $\begin{array}{r}2.038 \\
.440\end{array}$ & $\begin{array}{r}905 \\
-900\end{array}$ & 17 & 86.2 & .5 \\
\hline $\begin{array}{r}99 \\
100\end{array}$ & $\begin{array}{l}1585 \\
1584\end{array}$ & $36^{\circ} 35^{\prime} 10^{\prime \prime}$ & $118^{\circ} 14^{\prime} 30^{\prime \prime}$ & 8,480 & $\stackrel{\mathbf{P}}{\mathbf{P}}$ & Biotite-..... & $16 / 28$ & $\begin{array}{r}.440 \\
370\end{array}$ & $\begin{array}{l}7.583 \\
7.373\end{array}$ & 13 & 81.8 & .5 \\
\hline & $1584-\mathrm{HBD}$ & & & & $\stackrel{\mathbf{P}}{\mathbf{P}}$ & Hornblende & $60 / 150$ & $\begin{array}{r}.370 \\
1.914\end{array}$ & $\begin{array}{r}7.373 \\
.620\end{array}$ & 11 & 79.1 & .2 \\
\hline 101 & 1585 & $36^{\circ} 17^{\prime} 10^{\prime \prime}$ & $118^{\circ} 08^{\prime} 20^{\prime \prime}$ & 9,500 & $\mathbf{P}$ & Biotite....... & $16 / 28$ & .479 & 7.047 & $\begin{array}{r}37 \\
6\end{array}$ & $\begin{array}{l}80.0 \\
79.8\end{array}$ & .84 \\
\hline 102 & 1586 & $36^{\circ} 25^{\prime} 04^{\prime \prime}$ & $118^{\circ} 16^{\prime} 23^{\prime \prime}$ & 9,680 & P & .....do...... & $10 / 16$ & .360 & 7. 632 & 10 & 80.5 & .4 \\
\hline 103 & 1587 & $36^{\circ} 35^{\prime} 04^{\prime \prime}$ & $118^{\circ} 24^{\prime} 09^{\prime \prime}$ & 9,280 & $\mathbf{P}$ & ...... do & $10 / 16$ & .393 & 7.623 & 4 & 78. & .6 \\
\hline & 1587-R & & & & $\mathbf{P}$ & .... do & $10 / 16$ & .338 & 7.623 & 10 & 78.4 & .6 \\
\hline & 1587-HBD & & & & P & Horn & $60 / 100$ & 1.694 & .508 & 14 & 84.0 & .6 \\
\hline 104 & 1588 & $36^{\circ} 34^{\prime} 25^{\prime \prime}$ & $118^{\circ} 19^{\prime} 06^{\prime \prime}$ & 11,530 & $\mathbf{P}$ & Blotite.... & $16 / 28$ & .396 & 6. 944 & 7 & 81. & .2 \\
\hline 105 & 1589 & $36^{\circ} 39^{\prime} 08^{\prime \prime}$ & $118^{\circ} 22^{\prime} 02^{\prime \prime}$ & 11,500 & $\mathbf{P}$ & ......do...... & $16 / 28$ & .350 & 7.17 & 16 & 79. & .5 \\
\hline 106 & 1590 & $36^{\circ} 33^{\prime} 34^{\prime \prime}$ & $118^{\circ} 17^{\prime} 27^{\prime \prime}$ & 13,777 & $\mathbf{P}$ & .....do..... & $16 / 28$ & .354 & 7.39 & 11 & 81. & .6 \\
\hline & $1590-R$ & & & & & .....do do.... & $16 / 28$ & .227 & 7.391 & 16 & 81.5 & .6 \\
\hline 107 & 1591 & $36^{\circ} 34^{\prime} 02^{\prime \prime}$ & $118^{\circ} 16^{\prime} 05^{\prime \prime}$ & 11,600 & $\mathrm{P}$ & ....do. & $16 / 2$ & .335 & 6. 932 & 7 & 79.3 & .8 \\
\hline 108 & 1592 & $36^{\circ} 35^{\prime} 34^{\prime \prime}$ & $118^{\circ} 13^{\prime} 18^{\prime \prime}$ & 7,680 & $\vec{P}$ & ....do do.... & $10 \%$ & .397 & 7. 725 & 8 & & .1 \\
\hline & 1592-HBD & & & & $\mathbf{P}$ & Hornblende & $28 /$ & 2. 069 & .459 & 20 & 81. & .6 \\
\hline & 1593 & $37^{\circ} 50^{\prime} 52^{\prime \prime}$ & $119^{\circ} 24^{\prime} 17^{\prime \prime}$ & 10,900 & $\mathbf{P}$ & Biotite.... & $16 / 28$ & .336 & 7.10 & 7 & 83. & \\
\hline 84 & 1594 & $37^{\circ} 52^{\prime} 41^{\prime \prime}$ & $119^{\circ} 20^{\prime} 38^{\prime \prime}$ & 8,700 & $\mathbf{P}$ & $\ldots . .$. do .... & $16 / 28$ & .410 & 7. 120 & 9 & 82.4 & .1 \\
\hline 45 & 1595 & $38^{\circ} 07^{\prime} 24^{\prime \prime}$ & $119^{\circ} 25^{\prime} 39^{\prime \prime}$ & 11,000 & $\mathbf{P}$ & .....do.... & $16 / 2$ & .441 & 7.29 & 10 & 81.0 & .8 \\
\hline 46 & 1596 & $38^{\circ} 07^{\prime} 32^{\prime \prime}$ & $119^{\circ} 26^{\prime} 08^{\prime \prime}$ & 9,200 & $\mathbf{P}$ & ....do... & $28 / 4$ & .475 & 6.9 & 9 & 81. & .1 \\
\hline 47 & 1597 & $38^{\circ} 08^{\prime} 54^{\prime \prime}$ & $119^{\circ} 25^{\prime} 36^{\prime \prime}$ & 7,950 & $\mathbf{P}$ & do... & $16 / 28$ & .402 & 7. 43 & 5 & 80.2 & .1 \\
\hline 48 & 1598 & $38^{\circ} 08^{\prime} 54^{\prime \prime}$ & $119^{\circ} 23^{\prime} 19^{\prime \prime}$ & 7,300 & $\mathbf{P}$ & -..do.... & $16 / 28$ & .368 & 7. 59 & 9 & 80.1 & .1 \\
\hline 49 & 1599 & $38^{\circ} 10^{\prime} 16^{\prime \prime}$ & $119^{\circ} 31^{\prime} 02^{\prime \prime}$ & 9,000 & $\mathbf{P}$ & do...... & $16 / 28$ & .437 & 7.2 & 10 & 81. & \\
\hline 85 & 1600 & $37^{\circ} 09^{\prime} 11^{\prime \prime}$ & $118^{\circ} 42^{\prime} 51^{\prime \prime}$ & 11,500 & $\overline{\mathbf{P}}$ & ....do... & $28 / 35$ & .361 & 6.464 & 11 & & 3 \\
\hline 86 & 1601 & $37^{\circ} 11^{\prime} 28^{\prime \prime}$ & $119^{\circ} 40^{\prime} 00^{\prime \prime}$ & 12,880 & $\mathrm{P}$ & do & $10 / 16$ & .364 & 7.276 & 9 & 82. & 5 \\
\hline & 1601-HBD & & & & $\mathbf{P}$ & Hornblende... & $28 / 60$ & 2.065 & .770 & 12 & 88.4 & .8 \\
\hline 109 & 1602 & $36^{\circ} 27^{\prime} 05^{\prime \prime}$ & $118^{\circ} 47^{\prime} 48^{\prime \prime}$ & 2,400 & $\mathbf{P}$ & 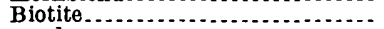 & $10 / 16$ & .383 & 7. 626 . & 6 & 91.7 & .1 \\
\hline 110 & 1603 & $36^{\circ} 26^{\prime} 56^{\prime \prime}$ & $118^{\circ} 46^{\prime} 24^{\prime \prime}$ & 3,050 & $\overline{\mathbf{P}}$ & ....do...... & $10 / 1$ & .354 & 7.716 & 8 & 92.6 & .1 \\
\hline 111 & 1604 & $36^{\circ} 25^{\prime} 54^{\prime \prime}$ & $118^{\circ} 45^{\prime} 18^{\prime \prime}$ & 3,900 & $\mathbf{P}$ & .....do... & $16 / 28$ & .367 & 7. 193 & 25 & 82.7 &.$\overline{3}$ \\
\hline 112 & 1605 & $36^{\circ} 26^{\prime} 20^{\prime \prime}$ & $118^{\circ} 44^{\prime} 22^{\prime \prime}$ & 4,050 & $\mathbf{P}$ & $\ldots$ do & $10 / 16$ & .367 & 7. 531 & 15 & 87.4 & \\
\hline & 1605-HBD & & & & $\mathbf{P}$ & Hornblende. & $28 / 60$ & 1. 338 & .888 & 20 & 90.1 & .2 \\
\hline & 1605-PL & & & & $\begin{array}{l}\mathrm{P} \\
\mathrm{P}\end{array}$ & $\begin{array}{l}\text { Plagioclase....... } \\
\text { K-feldspar }\end{array}$ & $\begin{array}{l}60 / 100 \\
28 / 60\end{array}$ & 2.027 & .254 & $\begin{aligned} 31 \\
2\end{aligned}$ & 88.1 & .6 \\
\hline 113 & $\begin{array}{l}1600-\mathrm{KF} \\
1606\end{array}$ & $36^{\circ} 26^{\prime} 29^{\prime \prime}$ & $118^{\circ} 43^{\prime} 12^{\prime \prime}$ & 4,800 & $\stackrel{P}{P}$ & $\begin{array}{l}\text { K-Ielaspar. } \\
\text { Biotite..... }\end{array}$ & $\begin{array}{l}28 / 00 \\
10 / 16\end{array}$ & $\begin{array}{l}.481 \\
.390\end{array}$ & $\begin{array}{r}7.239 \\
7.239\end{array}$ & $\begin{array}{r}2 \\
19\end{array}$ & $\begin{array}{l}87.0 \\
88.5\end{array}$ & .0 \\
\hline
\end{tabular}


TABLE 5

TABLE 5.-Potassium-argon analyses and location of sample localities-Continued

\begin{tabular}{|c|c|c|c|c|c|c|c|c|c|c|c|c|}
\hline $\begin{array}{c}\text { Location } \\
\text { No. } \\
\text { (pl.i) }\end{array}$ & KA No. & $\begin{array}{l}\text { Latitudo } \\
\text { (N.) }\end{array}$ & $\begin{array}{l}\text { Longitude } \\
(W .)\end{array}$ & $\begin{array}{c}\text { Elevation } \\
\text { (ft) }\end{array}$ & $\begin{array}{l}\text { Picked (P) } \\
\text { or un- } \\
\text { picked (U) }\end{array}$ & Mineral & $\begin{array}{c}\text { Size } \\
\text { (standard } \\
\text { mesh) }\end{array}$ & $\begin{array}{l}\text { Weight } \\
\text { (grams) }\end{array}$ & $\underset{\text { percent) }}{\mathbf{K}(\mathbf{w t}}$ & $\underset{\text { (percent) }}{\mathrm{Ar}_{\mathrm{t}^{40}}}$ & $\underset{\left(10^{\circ} \mathrm{yr}\right)}{\mathrm{Ag \theta}}$ & $\begin{array}{c}\delta(x-y) \\
\text { (percent) }\end{array}$ \\
\hline $\begin{array}{l}114 \\
115\end{array}$ & $\begin{array}{l}1607 \\
1608\end{array}$ & $\begin{array}{l}36^{\circ} 27^{\prime} 48^{\prime \prime} \\
36^{\circ} 27^{\prime 222^{\prime \prime}}\end{array}$ & $\begin{array}{l}118^{\circ} 37^{\prime} 56^{\prime \prime} \\
118^{\circ} 33^{\prime} 22^{\prime \prime}\end{array}$ & $\begin{array}{r}7,000 \\
12,340\end{array}$ & $\stackrel{P}{\mathbf{P}}$ & $\begin{array}{l}\text { Biotite.......... } \\
\text { (...do do......... }\end{array}$ & $\begin{array}{r}8 / 10 \\
16 / 28\end{array}$ & $\begin{array}{l}.436 \\
.368\end{array}$ & $\begin{array}{l}7.636 \\
7.099\end{array}$ & $\begin{array}{l}26 \\
15\end{array}$ & $\begin{array}{l}88.9 \\
90.5\end{array}$ & 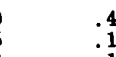 \\
\hline$\ldots$ & $1008-\mathrm{R}$ & $38^{\circ} 27^{\prime} 48^{\prime \prime}$ & $11^{\circ} 32^{\prime} 46^{\prime \prime}$ & 10.800 & $\stackrel{p}{P}$ & (n) & $\begin{array}{l}16 / 28 \\
16 / 28\end{array}$ & $\begin{array}{l}.000 \\
.374\end{array}$ & 7.099 & 10 & 93.2 & 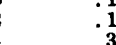 \\
\hline 116 & $\begin{array}{l}16009-\mathrm{EBD} \\
1609\end{array}$ & $36^{\circ} 27^{\prime} 48^{\prime \prime}$ & & 10,800 & $\stackrel{P}{P}$ & Hornblende... & $\begin{array}{l}180 / 68 \\
28 / 60\end{array}$ & $\begin{array}{l}.354 \\
1.774\end{array}$ & $\begin{array}{r}7.2900 \\
.974\end{array}$ & 17 & $\begin{array}{l}83.4 \\
93.0\end{array}$ & 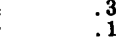 \\
\hline 117 & 160 & $36^{\circ} 27^{\prime} 37^{\prime \prime}$ & $118^{\circ} 33^{\prime} 43^{\prime \prime}$ & 11,600 & $\stackrel{p}{p}$ & Biotite.............. & $\begin{array}{r}28 / 60 \\
28 / 60\end{array}$ & .291 & 6.773 & 19 & 88.3 & .6 \\
\hline 140 & $l_{1621}^{10101 B D}$ & $\begin{array}{l}35^{\circ} 12^{\prime} 43^{\prime \prime} \\
382^{\prime \prime}\end{array}$ & $118^{\circ} 32^{\prime} 42^{\prime \prime}$ & 2,700 & $\stackrel{P}{P}$ & Biotite........ & $\begin{array}{l}28 / 60 . \\
10 / 16 \\
10 / 28\end{array}$ & $\begin{array}{r}1.656 \\
.323 \\
.300\end{array}$ & $\begin{array}{l}2.136 \\
7.272 \\
7727\end{array}$ & $\begin{array}{l}14 \\
19\end{array}$ & $\begin{array}{r}86.4 \\
81.2\end{array}$ & $\begin{array}{r}2.0 \\
.4\end{array}$ \\
\hline & 1624-HBD & $38^{\circ} 04^{\prime} 18^{\prime \prime}$ & $120^{\circ} 10^{\prime} 46^{\prime \prime}$ & & $\stackrel{P}{P}$ & Hornblende.. & $\begin{array}{l}186 / 28 \\
28 / 60\end{array}$ & $\begin{array}{r}.300 \\
1.517\end{array}$ & $\begin{array}{l}7.727 \\
.727\end{array}$ & ${ }_{11}^{6}$ & $\begin{array}{l}138 \\
136\end{array}$ & \\
\hline 118 & 1626 & $36^{\circ} 28^{\prime} 35^{\prime \prime}$ & $118^{\circ} 54^{\prime} 13^{\prime \prime}$ & $\cdots$. & $\mathrm{P}_{\mathrm{D}}$ & Biotite............. & $8 / 10$ & $\begin{array}{l}.280 \\
.280\end{array}$ & 7. 729 & 17 & $\begin{array}{r}93.5 \\
9\end{array}$ & \\
\hline 87 & 1626-HBD & $37^{\circ} 17^{\prime} 45^{\prime \prime}$ & $111^{\circ} 31^{\prime} 52^{\prime \prime}$ & & $\bar{P}$ & Hornblende.. & $28 / 60$ & 2. 148 & .617 & 25 & 101 & \\
\hline 87 & ${ }_{1627-F I B D}^{1627}$ & $37.1740^{\circ}$ & 1193162 & & ${ }_{P}^{P}$ & $\begin{array}{l}\text { Biotite. } \\
\text { Hornblende.. }\end{array}$ & $\begin{array}{l}10 / 16 \\
28,60\end{array}$ & $\begin{array}{r}.206 \\
2061\end{array}$ & $\begin{array}{l}7.694 \\
628\end{array}$ & $\begin{array}{r}8 \\
30\end{array}$ & $\begin{array}{l}97.7 \\
100\end{array}$ & \\
\hline 88 & חקח & $37^{\circ} 19^{\prime} 05^{\prime \prime}$ & $119^{\circ} 39^{\prime} 20^{\prime \prime}$ & & $\mathbf{P}$ & Biotite............ & $\begin{array}{l}16 / 28 \\
16 / 20\end{array}$ & .280 & 7. 768 & 14 & 104 & \\
\hline 110 & ${ }_{1029}^{1028-\mathrm{HBD}}$ & $36^{\circ} 23^{\prime} 33^{\prime \prime}$ & $118^{\circ} 57^{\prime} 55^{\prime \prime}$ & & $\bar{P}$ & Hornblende...... & $16 / 28$ & 2.051 & .721 & 18 & 144 & \\
\hline 110 & $1029-\mathrm{HBD}$ & 30.2535 & $1180600^{\circ}$ & & $\mathbf{P}$ & $\begin{array}{l}\text { Biotite... } \\
\text { Hornblende. }\end{array}$ & $\begin{array}{r}10 / 16 \\
28 / 60\end{array}$ & .305 & $\begin{array}{l}7.564 \\
456\end{array}$ & 8 & $\begin{array}{l}103 \\
105\end{array}$ & .3 \\
\hline 120 & 1630 & $36^{\circ} 17^{\prime} 45^{\prime \prime}$ & $110^{\circ} 04^{\prime} 40^{\prime \prime}$ & & P & $\begin{array}{l}\text { Hornblenae... } \\
\text { Biotite....... }\end{array}$ & $\begin{array}{l}28 / 60 \\
28 / 60\end{array}$ & $\begin{array}{r}21227 \\
.218\end{array}$ & $\begin{array}{r}.450 \\
6.540\end{array}$ & 13 & 1114 & .24 \\
\hline no & $1630-\mathrm{HBD}$ & $34^{\circ} 53^{\prime} 49^{\prime \prime}$ & $118^{\circ} 55^{\prime} 01^{\prime \prime}$ & & $P$ & Hornblend $\theta_{-} .$. & $28 / 60$ & .915 & 1.762 & 11 & 115 & \\
\hline $\begin{array}{r}142 \\
89\end{array}$ & $\begin{array}{l}1631 \\
1632\end{array}$ & - $37^{\circ} 58^{\prime} 45^{\prime \prime}$ & $120^{\circ} 20^{\prime} 03^{\prime \prime}$ & $\cdots$ & $P$ & Biotite......... & $\begin{array}{l}28 / 60 \\
16 / 28\end{array}$ & .278 & $\begin{array}{r}7.349 \\
7438\end{array}$ & 21 & ${ }_{152}^{86.1}$ & \\
\hline & 1032 -HBDD & $38^{\circ} 25^{\prime} 00^{\prime \prime}$ & & & $\stackrel{p}{\mathbf{p}}$ & Hornblende. & $\begin{array}{l}10 / 28 \\
16 / 28\end{array}$ & 1. 773 & $\begin{array}{l}.458 \\
.955\end{array}$ & 26 & 162 & .1 \\
\hline 61 & 1633 & $38^{\circ} 25^{\prime} 00^{\prime \prime}$ & $120^{\circ} 27^{\prime} 01^{\prime \prime}$ & & $\mathbf{p}$ & Biotite........ & $16 / 28$ & .210 & 7.805 & 16 & 89.1 & .0 \\
\hline 90 & & $37^{\circ} 59^{\prime} 29^{\prime \prime}$ & $120^{\circ} 16^{\prime} 37^{\prime \prime}$ & & $\stackrel{P}{\mathbf{P}}$ & $\begin{array}{l}\text { Hornblende.... } \\
\text { Biotitite }\end{array}$ & $\begin{array}{l}16 / 28 \\
16628\end{array}$ & 1.893 & .839 & & 120 & $\because 0$ \\
\hline 90 & $1034-\mathrm{HBD}$ & & 120200 & & $\stackrel{p}{\mathrm{P}}$ & Hornblende & $\begin{array}{l}16 / 28 \\
28 / 60\end{array}$ & .244 & 7.763 & 5 & 144 & .3 \\
\hline 51 & 1036 & $38^{\circ} 18^{\prime} 02^{\prime \prime}$ & $120^{\circ} 16^{\prime} 38^{\prime \prime}$ & & $\mathbf{P}$ & Biotite............ & $16 / 28$ & $\begin{array}{l}.261 \\
.261\end{array}$ & 7.812 & 20 & $\begin{array}{l}2000 \\
125\end{array}$ & $: 1$ \\
\hline 5 & 1635-HBD & $38^{\circ} 23^{\prime 1} 6^{\prime \prime}$ & $120^{\circ} 11^{\prime} 01^{\prime \prime}$ & & $p$ & Hornblende... & $28 / 100$ & 2. 118 & 1.368 & 4 & 148 & \\
\hline 52 & ${ }_{1682-F B D}$ & $38^{\circ} 23^{\prime} 16^{\prime \prime}$ & $120^{\circ} 11^{\prime} 01^{\prime \prime}$ & & $\stackrel{P}{P}$ & Biotite........ & $28 / 60$ & & 7.535 & 11 & 96.0 & 6 \\
\hline 91 & $1603-\mathrm{BD}$ & 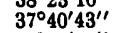 & $119^{\circ} \mathbf{4 5 ^ { \prime } 4 7 ^ { \prime \prime }}$ & & ${ }_{\mathrm{P}}^{\mathrm{P}} \mathrm{r}$ & $\begin{array}{l}\text { Hornblende. } \\
\text { - do }\end{array}$ & $\begin{array}{l}28 / 60 \\
16 / 28\end{array}$ & 2.076 & .956 & 19 & 95.8 & .4 \\
\hline 63 & 1084 & $38^{\circ} 13^{\prime} 01^{\prime \prime}$ & $120^{\circ} 22^{\prime} 13^{\prime \prime}$ & & $\mathbf{P}$ & Biotite & $\begin{array}{l}101 / 28 \\
16 / 28\end{array}$ & $\begin{array}{l}1.171 \\
.311\end{array}$ & $\begin{array}{l}1.004 \\
7.315\end{array}$ & $\begin{array}{r}11 \\
9\end{array}$ & 145 & .6 \\
\hline & 1664-HBD & & & & & Hornblende.. & $28 / 60$ & 1. 269 & .713 & 11 & 148 & .6 \\
\hline 92 & $1605-\mathrm{HBD}$ & $37^{\circ} 33^{\prime} 07^{\prime \prime \prime}$ & $119^{\circ} 40^{\prime} 53^{\prime \prime}$ & & 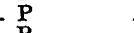 & 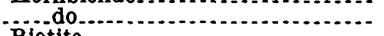 & $28 /$ & 2.114 & .783 & 9 & 108 & .4 \\
\hline $\begin{array}{r}03 \\
141\end{array}$ & 1606 & $\begin{array}{l}37^{\circ} 06^{\prime} 25^{\prime \prime} \\
35^{\circ} 01^{\prime} 35^{\prime \prime}\end{array}$ & $\begin{array}{l}110^{\circ} 44^{\prime} 36^{\prime \prime} \\
118^{\circ} 20^{\prime} 50^{\prime \prime}\end{array}$ & & $\stackrel{P}{\mathbf{P}}$ & Biotite......... & $\begin{array}{r}28 / 60 \\
28 / 60\end{array}$ & .364 & $\begin{array}{l}7.709 \\
7.207\end{array}$ & $\begin{array}{r}5 \\
13\end{array}$ & $\begin{array}{l}107 \\
80.4\end{array}$ & .5 \\
\hline & $1067-\mathrm{EBD}$ & & & & & Hornblende & $28 / 60$ & $\begin{array}{l}.0399 \\
1.891\end{array}$ & $\begin{array}{l}. .206 \\
.936\end{array}$ & 17 & 81.4 & .0 \\
\hline 143 & $1608-\mathrm{HBD}$ & $34^{\circ} 39^{\prime} 34^{\prime \prime}$ & $118^{\circ} 27^{\prime} 38^{\prime \prime}$ & & $\mathbf{p}$ & ......do.............. & $16 / 28$ & 2.511 & 1.075 & 16 & 70.6 & .5 \\
\hline 144 & 1070-HBD & (18'67"' & $119^{\circ} 03^{\prime} 32^{\prime \prime}$ & & $\vec{p}$ & ......do. & $28 / 60$ & 2.412 & 1. 213 & 5 & 69.7 & .3 \\
\hline 145 & 1671 -HBD & $\begin{array}{l}34^{\circ} 29^{\prime} 19^{\prime \prime \prime} \\
34^{\circ} 0^{\prime \prime} 5^{\prime \prime \prime}\end{array}$ & $\begin{array}{l}117^{\circ} 52^{\prime}, 1^{\prime \prime \prime} \\
110^{\circ} 21^{\prime} 6^{\prime \prime}\end{array}$ & 3,300 & $\stackrel{P}{P}$ & ado-a.......... & $10 / 16$ & 2.015 & .834 & 10 & $\begin{array}{r}76.9 \\
67 .\end{array}$ & .1 \\
\hline & ${ }_{1672-\mathrm{HBD}}^{1672}$ & ${ }^{\circ} 50^{\prime} 35^{\prime \prime}$ & $119^{\circ} 21^{\prime} 06^{\prime \prime}$ & 3,950 & $\underset{\mathbf{P}}{\mathbf{P}}$ & $\begin{array}{l}\text { Biotite } \\
\text { Hornblende..................... }\end{array}$ & $\begin{array}{l}28 / 60 \\
28 / 60\end{array}$ & $\begin{aligned} .390 \\
2.272\end{aligned}$ & $\begin{array}{l}7.646 \\
1.069\end{array}$ & $\begin{array}{l}14 \\
11\end{array}$ & $\begin{array}{l}67.2 \\
69.5\end{array}$ & .0 \\
\hline 147 & 1673 & $34^{\circ} 49^{\prime} 28^{\prime \prime}$ & $118^{\circ} 59^{\prime} 27^{\prime \prime}$ & 5,460 & P & Biotite & $28 / 60$ & .414 & 7.393 & 5 & 76.9 & .3 \\
\hline 148 & 167 & $34^{\circ} 27^{\prime} 65^{\prime \prime}$ & $117^{\circ} 51^{\prime} 41^{\prime \prime}$ & 3,500 & $\stackrel{p}{\mathbf{p}}$ & Ho.d & $16 /$ & .336 & 7.329 & 13 & 68.1 & .1 \\
\hline 149 & ${ }_{1675}^{167-\mathrm{HBD}}$ & $34^{\circ} 20^{\prime} 61^{\prime \prime}$ & $117^{\circ} 65^{\prime} 16^{\prime \prime}$ & 6,810 & $\stackrel{P}{P}$ & $\begin{array}{l}\text { Hornblende...... } \\
\text { Biotite }\end{array}$ & $\begin{array}{l}16 / 28 \\
16 / 28\end{array}$ & $\begin{array}{r}2.193 \\
.337\end{array}$ & $\begin{array}{l}1.028 \\
7.500\end{array}$ & $\begin{array}{l}29 \\
13\end{array}$ & $\begin{array}{l}73.1 \\
64.7\end{array}$ & .1 \\
\hline 160 & 1670 & $34^{\circ} 4^{\circ} 1^{\prime} 56^{\prime \prime \prime}$ & $118^{\circ} 56^{\prime} 00^{\prime \prime}$ & 3,800 & $P$ & ....do & $28 / 80$ & .327 & 7.485 & 5 & 66.1 & $\cdot 1$ \\
\hline 181 & 1677 & $34^{\circ} 09^{\prime}$ & $116^{\circ} 58^{\prime}$ & & $\bar{p}$ & - do & $16 / 28$ & .314 & 7.574 & 5 & 69.7 & .5 \\
\hline 54 & $\begin{array}{l}1677-\mathrm{HBD} \\
1678\end{array}$ & $38^{\circ} 47^{\prime} 02^{\prime \prime}$ & $120^{\circ} 12^{\prime} 63^{\prime \prime}$ & 5,360 & $\underset{\mathbf{P}}{\mathbf{P}}$ & $\begin{array}{l}\text { Hornblende....... } \\
\text { Biotite............ }\end{array}$ & $\begin{array}{l}16 / 28 \\
16 / 28\end{array}$ & 3.014 & $\begin{array}{r}.866 \\
7.467\end{array}$ & $\begin{array}{r}9 \\
13\end{array}$ & $\begin{array}{l}72.6 \\
92.8\end{array}$ & .2 \\
\hline & 1678-HBD & & & & & Hornblende......... & $18 / 28$ & 2.414 & .668 & 9 & 97.6 & 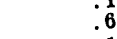 \\
\hline 55 & & $\begin{array}{l}38^{\circ} 48^{\prime 2} 20^{\prime \prime \prime} \\
3^{\prime}\end{array}$ & $\begin{array}{l}120^{0} 07^{\prime} 18^{\prime \prime \prime} \\
1110^{\prime \prime} 30^{\prime} 77^{\prime \prime}\end{array}$ & 6,310 & $\frac{p}{p}$ & Blotite.......... & $16 \%$ & .338 & 7.515 & 6 & 93.7 & 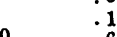 \\
\hline 162 & $\begin{array}{l}1680 \\
1680-\mathrm{HBD}\end{array}$ & & $117^{\circ} 39^{\prime} 07^{\prime \prime}$ & 7, & $\underset{\mathrm{P}}{\mathrm{P}}$ & Hornblende.... & $\begin{array}{r}28 / 60 \\
2880\end{array}$ & .341 & 6. 578 & 99 & 61.0 & 0 \\
\hline 163 & 1682-HBD & $34^{\circ} 52^{\prime} 54^{\prime \prime}$ & $118^{\circ} 54^{\prime} 04^{\prime \prime}$ & 3,150 & P & ndo ....... & $\begin{array}{l}28860 \\
16 / 28\end{array}$ & $\begin{array}{l}2.136 \\
2.179\end{array}$ & $\begin{array}{l}1.067 \\
.324\end{array}$ & $\frac{92}{43}$ & $\begin{array}{l}71.0 \\
77.4\end{array}$ & 4 \\
\hline 50 & 1683 & & & 880 & $\mathbf{p}$ & $\theta \ldots$ & $10 / 16$ & .318 & 7. 587 & 3 & 102 & \\
\hline 154 & $\begin{array}{l}1883-\mathrm{HBD} \\
1696\end{array}$ & $34^{\circ} 18^{\prime} 42^{\prime \prime}$ & $18^{\circ} 08^{\prime} 15^{\prime \prime}$ & 2.930 & $\underset{\mathbf{P}}{\mathbf{P}}-\mathrm{r}-\mathrm{P}$ & $\begin{array}{l}\text { Hornblende. } \\
\text { Biotite }\end{array}$ & $10 / 16$ & 2. 525 & .597 & 8 & 100 & 8 \\
\hline Lore & 1696-HBD & & & & $\mathbf{P}$ & Hornblende.... & ${ }_{28}^{288}$ & $\begin{array}{l}.340 \\
1.683\end{array}$ & $\begin{array}{l}7.000 \\
.864\end{array}$ & ${ }_{10}^{22}$ & $\begin{array}{l}60.8 \\
70.0\end{array}$ & 0 \\
\hline 67 & 1697 & $38^{\circ} 27^{\prime} 00^{\prime \prime \prime}$ & $119^{\circ} 27^{\prime} 29^{\prime \prime}$ & 6,020 & P & Blotite ................... & 16 & $\begin{array}{r}.005 \\
.295\end{array}$ & 7.286 & 3 & 1190 & .7 \\
\hline 58 & $\begin{array}{l}1698 \\
1698-\mathrm{HBD}\end{array}$ & & & & $\stackrel{P}{\mathbf{P}}$ & Hornblende............ & $\begin{array}{l}28 / 60 \\
28,60\end{array}$ & .293 & $\begin{array}{l}7.538 \\
775\end{array}$ & $\begin{array}{l}6 \\
6\end{array}$ & $\begin{array}{l}108 \\
140\end{array}$ & .1 \\
\hline 50 & 1690 & $38^{\circ} 46^{\prime} 23^{\prime \prime}$ & $120^{\circ} 25^{\prime} 45^{\prime \prime}$ & 3,400 & $\mathbf{P}$ & Biotite & $\begin{array}{l}28 / 60 \\
2800\end{array}$ & $\begin{array}{r}1.081 \\
.365\end{array}$ & 7.875 & 16 & 117 & .0 \\
\hline 60 & $\begin{array}{l}\text { 1690-HBD } \\
\text { 1700-HBD }\end{array}$ & $38^{\circ} 46^{\prime} 17^{\prime \prime}$ & $120^{\circ} 29^{\prime} 34^{\prime \prime}$ & 3,320 & $\underset{\mathbf{P}}{\mathrm{P}}-1-10$ & Hornblende & $\begin{array}{l}28 / 60 \\
1628\end{array}$ & $\begin{array}{l}1.665 \\
2522\end{array}$ & .713 & $\begin{array}{r}4 \\
28\end{array}$ & $\begin{array}{l}140 \\
138\end{array}$ & 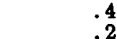 \\
\hline 18 & חמידומ 1 & & & 1,500 & $\hat{\mathbf{P}}$ & en. & $16 / 28$ & .298 & 7.838 & $\begin{array}{r}28 \\
4\end{array}$ & 143 & \\
\hline & 1701-HBD & $30037^{\prime} 0^{\prime \prime}$ & $1900270^{\prime \prime}$ & & $\mathbf{p}$ & lende.... & $16 \%$ & 2.245 & .576 & 25 & 146 & .2 \\
\hline 19 & 1702 & $39^{\circ} 37^{\prime} 00^{\prime \prime}$ & $129^{\circ} 27^{\prime} 06^{\prime \prime}$ & 5,760 & P & & 287 & .303 & 7. 153 & 3 & 153 & .1 \\
\hline 209 & DKA 1028 & $37^{\circ} 67^{\prime} 10^{\prime \prime}$ & $119^{\circ} 14^{\prime} 08^{\prime \prime}$ & & U & e................ & $26 / 6$ & 2.097 & $\begin{array}{r}.773 \\
7.495\end{array}$ & $\begin{array}{l}5 \\
8\end{array}$ & $\begin{array}{l}150 \\
83.7\end{array}$ & \\
\hline 210 & DKA 1029 & & & & $\mathrm{U}$ & $\cdots$. & $80 / 100$ & .222 & 7.412 & 10 & 84.8 & \\
\hline & & & & & $\mathrm{U}$ & lende..... & $100 / 150$ & 1.501 & .777 & 29 & 94 & \\
\hline & MKA 41 & & & & $\mathrm{U}$ & Bio & $80 /$ & .698 & $\begin{array}{l}6.050 \\
7.88\end{array}$ & 11 & 93. & \\
\hline & & $\mathbf{3}$ & $119^{\circ} 14$ & $\cdots$ & $\mathrm{U}$ & . & $80 /$ & .241 & $\begin{array}{l}7.528 \\
653\end{array}$ & $\begin{array}{r}6 \\
22\end{array}$ & $\begin{array}{l}83 . \\
92\end{array}$ & \\
\hline 213 & DKA 1030 & 等 & $119^{\circ} 12$ & & $\underline{U}$ & ......... & 80 & $\begin{array}{l}1.478 \\
301\end{array}$ & $\begin{array}{r}.653 \\
7.669\end{array}$ & $\begin{array}{l}22 \\
10\end{array}$ & & \\
\hline & MKA 410 & $57^{\prime} 40^{\prime \prime}$ & $110^{\circ} 12^{\prime} 3$ & & $\mathrm{U}$ & lende........ & $\begin{array}{r}800 / 100 \\
100 / 150\end{array}$ & 2.696 & $\begin{array}{r}7.669 \\
.446\end{array}$ & 22 & 206.0 & \\
\hline & $\mathrm{BKA}$ & & & & $\mathrm{U}$ & Bio & $60 / 80$ & $\begin{array}{l}2.090 \\
1.061\end{array}$ & $\begin{array}{r}.440 \\
6.250\end{array}$ & 33 & 82.0 & \\
\hline & MKA 42 & & iit & $\ldots$ & U & ..... & 40 & 1.0 & 6. 960 & 9 & 89.6 & \\
\hline 210 & & & & & $\mathrm{U}$ & (1) & $80 / 100$ & 1.109 & 7. 470 & 12 & 87.7 & \\
\hline 21 & $61-192$ & $37^{\circ} 511^{\prime} 30^{\prime \prime \prime}$ & $119^{\circ} 04$ & & $\mathrm{U}$ & nde..... & $100 \%$ & .993 & .3 & 15 & 85 & \\
\hline 21 & $\begin{array}{l}\text { BKA 487 } \\
\text { MKA 458 }\end{array}$ & $\begin{array}{l}37^{\circ} 464^{\prime 62} 0^{\prime \prime \prime} \\
37^{\circ} 46^{\prime 2} 20^{\prime \prime \prime}\end{array}$ & $119^{\circ} 04$ & & $\stackrel{\mathrm{U}}{\mathrm{U}}$ & & $40 /$ & .671 & 7.4 & 21 & 87.9 & \\
\hline & & & 年1 & 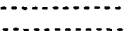 & U & de................. & $\begin{array}{c}100 / 115 \\
60 / 80\end{array}$ & 1.077 & $\begin{array}{r}.643 \\
6.820\end{array}$ & & $\begin{array}{l}97.1 \\
82.4\end{array}$ & \\
\hline & BKA 657 & 4 & 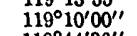 & ............ & $\mathrm{U}$ & , & & $\begin{array}{l}1.544 \\
.840\end{array}$ & $\begin{array}{l}0.820 \\
6.240\end{array}$ & & & $\cdots .$. \\
\hline & 61-041 & & & $\cdots$ & $\mathrm{U}$ & $\theta_{1}, \ldots \ldots$ & & .580 & 8.5 & & 109.9 & \\
\hline 221 & $\begin{array}{l}61-042 \\
61-001 \\
61\end{array}$ & $00625^{\prime \prime \prime}$ & & & U & $=1$ & & .442 & 7.6 & & & \\
\hline 221 & $\begin{array}{l}61-001 \\
61-020\end{array}$ & $\begin{array}{l}15^{15}, 50^{\prime \prime \prime} \\
10^{\prime} 50^{\prime \prime}\end{array}$ & & & $\begin{array}{l}\mathrm{U} \\
\mathrm{U}\end{array}$ & ...... & $60 /$ & . 559 & 7.3 & & & \\
\hline 222 & MKA & (3) & ${ }_{11}^{11}$ & & $\mathrm{U}$ & de........ & $\begin{array}{l}88 / 100 \\
60 / 80\end{array}$ & $\begin{array}{l}.490 \\
.311\end{array}$ & $\begin{array}{r}.607 \\
\text { 3. } 400\end{array}$ & $\frac{12}{21}$ & $\begin{array}{l}83.3 \\
134.0\end{array}$ & \\
\hline 201 & $61-0$ & $55^{\prime} 10^{\prime \prime}$ & 等 & $\cdots \cdot$ & $\mathrm{U}$ & Hornble & & .821 & $\begin{array}{l}.509 \\
.599\end{array}$ & 12 & 155.5 & \\
\hline & $01-8$ & & & .... & $\mathrm{U}$ & Horiste & & .945 & .5 & 15 & 163.1 & \\
\hline 22 & $61-045$ & & $118^{\circ} 02$ & $\ldots . .$. & $\mathrm{U}$ & ...... & & .623 & .487 & 17 & 177.6 & \\
\hline $\begin{array}{l}224 \\
225\end{array}$ & $\begin{array}{l}61-0.44 \\
61-005\end{array}$ & $\begin{array}{l}37^{\circ} 56^{\prime} 20^{\prime \prime} \\
3\end{array}$ & $\begin{array}{l}117^{\circ} 59^{\prime} 05^{\prime \prime} \\
118^{\circ} 20^{\prime} 10^{\prime \prime}\end{array}$ & - & $\mathrm{U}$ & Biotite & $\begin{array}{r}100 / 115 \\
80 / 100\end{array}$ & $\begin{array}{l}.437 \\
.859\end{array}$ & $\begin{array}{l}1.050 \\
6.960\end{array}$ & $\begin{array}{r}15 \\
6\end{array}$ & $\begin{array}{l}162.6 \\
156.7\end{array}$ & \\
\hline
\end{tabular}


TABLE 5.-Potassium-argon analyses and location of sample localities-Continued

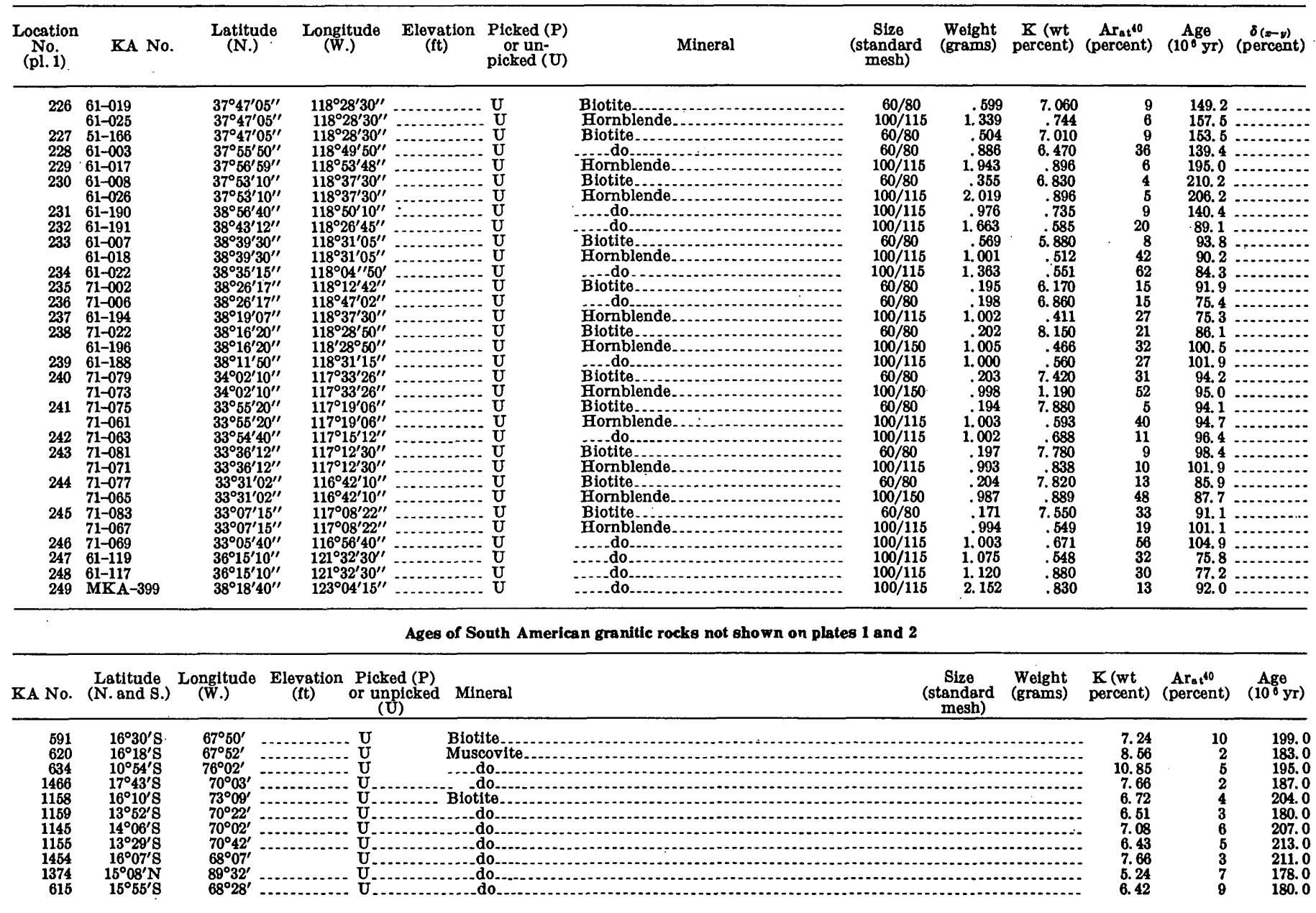


TABLE 6.-Rock name and description of sample locality

[Latitudes and longitudes given in table 5]

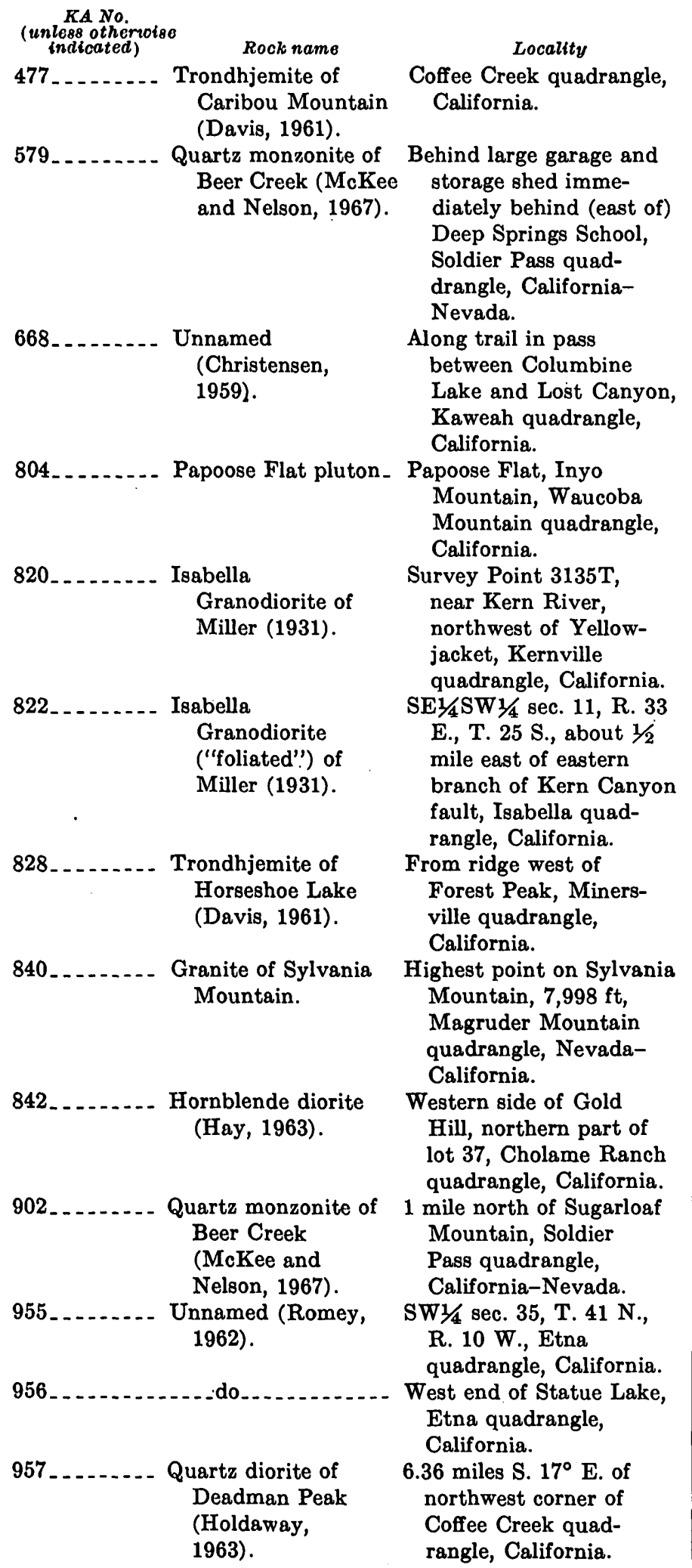

TABLE 6.-Rock name and description of sample locality-Con KA No.

(unless otherwoise Rock name Locality
indicated)

1432 . . ...... Elephant Butte $1,000 \mathrm{ft}$ south of Rock 1963).

Creek in canyon of

North Fork of Feather River, Pulga quadrangle, California.

1436 1 . Do.

$1 / 2$ mile north or Work-
(Gromme, 1963). man's Bar in canyon of North Fork of Feather River, Pulga quadrangle, California.

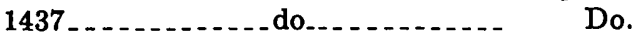

1438 . . . . Merrimac pluton 1 mile southwest of (Gromme, 1963). Merrimac near Coon Creek, Pulga quadrangle, California.

1440 $1 / 4$ mile north of Cresta (Gromme, 1963). powerhouse, in canyon of North Fork of Feather River, Pulga quadrangle, Califorina. Do.

1442 (Gromme, 1963).

At Workman's Bar, in canyon of North Fork of Feather River, Pulga quadrangle, California.

$1449 \ldots \ldots$. . . . . . do................ Do.

1501 . . . . . Unnamed. . . . . . . . Deans Ridge, Eagle Lake, at $5,600 \mathrm{ft}$ on dirt road, Fredonyer Peak quadrangle, California.

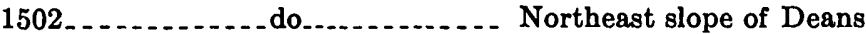
Ridge, at $5,350 \mathrm{ft}$ on road, Fredonyer Peak quadrangle, California.

1503 . . . . . . . . do... . . . . . . On Janesville Grade, at ridge line of secondary ridge immediately east of main volcaniccapped ridge, Susanville quadrangle, California.

$1504 \ldots \ldots$. . . . . . . do . . . . . . . . Head of Janesville Grade, at intersection of Thompson Creek Road and road to Thompson Peak lookout, Kettle Rock quadrangle, California.

1506

$1 / 4$ mile west of Forest Service Road 27N03, on Road 27N12, Plumas National Forest, Milford quadrangle, California. 
TABLE 6.-Rock name and description of sample locality-Con.

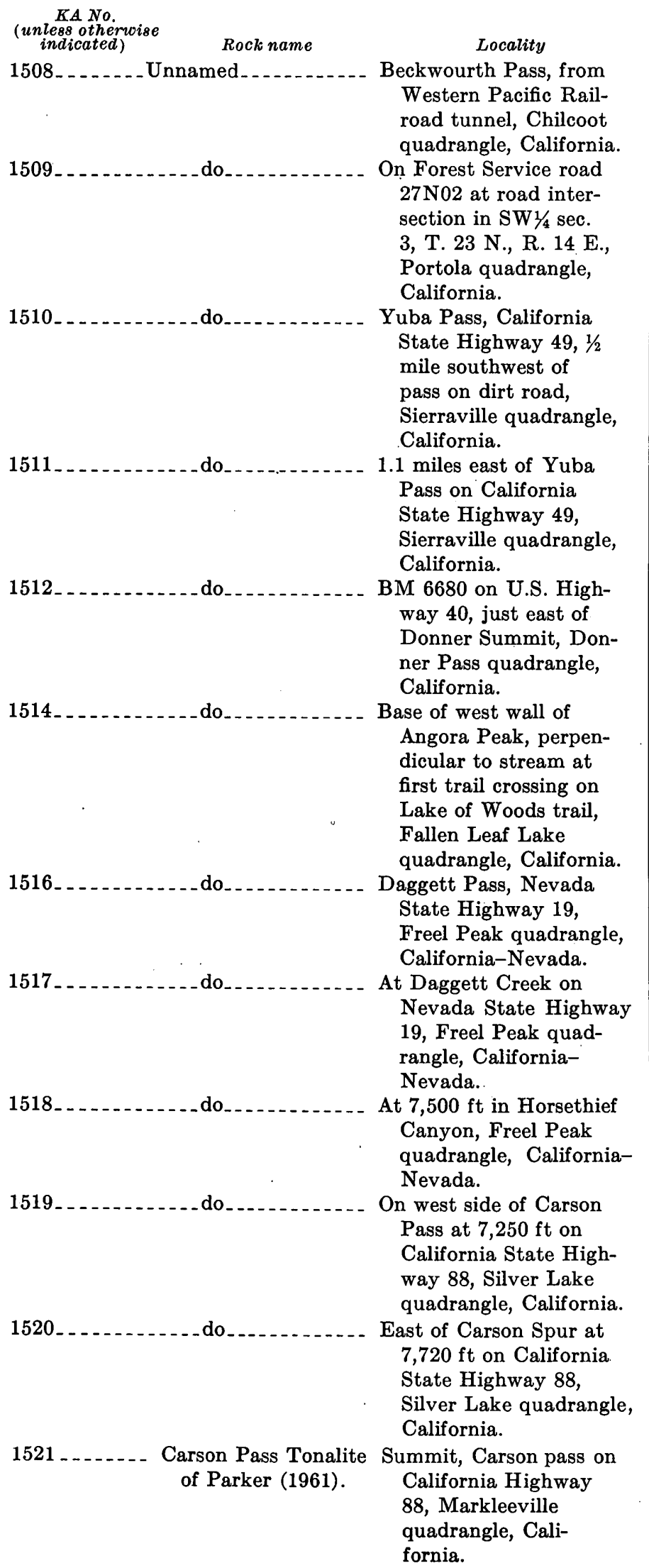

TABLE 6.-Rock name and description of sample locality-Con. KA No.

\begin{tabular}{|c|c|}
\hline $\begin{array}{c}\text { KA No. } \\
\text { (unless otherwise } \\
\text { indicated) }\end{array}$ & Rock name \\
\hline $1523 \ldots$ & $\begin{array}{l}\text { Stanislaus Meadow } \\
\text { Adamellite of } \\
\text { Parker (1961). }\end{array}$ \\
\hline $1524 \ldots \ldots$ & Unnamed \\
\hline $1525 \ldots \ldots \ldots$ & $\begin{array}{l}\text { Half Dome Quartz } \\
\text { Monzonite } \\
\text { (Calkins, 1930). }\end{array}$ \\
\hline $1526 \ldots \ldots$ & $\begin{array}{l}\text { Transition zone be- } \\
\text { tween Half Dome } \\
\text { Quartz Monzonite } \\
\text { and Cathedral } \\
\text { Peak Granite } \\
\text { (Calkins, 1930). }\end{array}$ \\
\hline
\end{tabular}

1527 Cathedral Peak Granite (Calkins, 1930).

1528 do

1530. do.

At $8,800 \mathrm{ft}$ on east side of Polly Dome, Tuolumne Meadows quadrangle, California.

At $8,800 \mathrm{ft}$ on north nose of Fairview Dome, Tuolumne Meadows quadrangle, California.

At $9,000 \mathrm{ft}$ on Echo Creek, Tuolumne Meadows quadrangle, California.

1531 - do.

At $9,000 \mathrm{ft}$ on shore of Babcock Lake, Tuolumne Meadows quadrangle, California.

1532 _ . . . . Half Dome Quartz Monzonite (Calkins, 1930).

1533

Cathedral Peak Granite (Calkins, 1930).

1534 Quartz monzonite of Topaz Lake (Cathedral Peak type) (Curtis, 1951).

1535 Quartz monzonite of Topaz Lake (Cathedral Peak type) (Slemmons, 1953).

1536 do
At $8,800 \mathrm{ft}$ on John Muir Trail in Lyell Fork Canyon, Tuolumne Meadows quadrangle, California.

At $8,800 \mathrm{ft}$ on John Muir Trail in Lyell Fork Canyon, Tuolumne Meadows quadrangle, California.

At 6,640 ft on Wolf Creek, Topaz Lake quadrangle, California.

Head of Clark Fork of Stanislaus River at $10,200 \mathrm{ft}$, Sonora Pass quadrangle, California.

At 7,450 ft on west side of The Iceberg, Sonora Pass quadrangle, California. 
TABLE 6.-Rock name and description of sample locality-Con.
TABLE 6.-Rock name and description of sample locality-Con.

$\begin{gathered}\text { KA No. } \\ \text { (unless otherwise } \\ \text { indicated) }\end{gathered}$
Rock name
Quartz monzonite of
Mono Recesses
(Cathedral Peak
type) (Sherlock
and Hamilton,
1958).

At 9,000 ft on Mono Creek, Mount Abbot quadrangle, California.

$1553 \ldots \ldots$. . . . . . do . . . . . . At 11,500 ft on west side of Mono Pass, Mount Abbot quadrangle, California.

$1554 \ldots . . . .$. Quartz monzonite of At $11,500 \mathrm{ft}$ on north Lagille Peak shoulder of Shakes(Cathedral Peak peare Peak, Mount type). Goddard quadrangle, California.

1555 At $8,080 \mathrm{ft}$ on Middle Fork of Kings River above junction with Palisade Creek, Mount Goddard quadrangle, California.

$1556 \ldots \ldots$. . . . Cathedral Peak type At 11,500 ft along trail on west side Kearsarge Pass, Mount Pinchot quadrangle, California.

1559 ....... Quartz monzonite of Top of hill 9247, northMono Recesses northwest of Devil's (Cathedral Peak Postpile National type). Monument, Devil's Postpile quadrangle, California.

$1560 \ldots \ldots$. . . . . . do... . . . . . At 9,000 ft in hill 9247, Devil's Postpile quadrangle, California.

1561 do........... At 11,500 ft in Granite Park, Mount Abbott quadrangle, California.

1562 ....... Isabella Granodior- At 2,800 ft in SW $1 / 4 \mathrm{sec}$. ite and its facies $\quad 32$, T. 24 S., R. 33 E., (Miller, 1931; Kernville 30 minute Miller and Webb, quadrangle, California. 1940).

1563 (19)

At 4,000 ft in center sec. 35, T. 22 S., R. 32 E., Kernville 30 minute quadrangle, California.

1564 do At 6,200 ft on road, south side of Horse Canyon, Camp Nelson quadrangle, California.

1565 Unnamed crossing of Boulder Creek on California State Highway 190, on west-facing side of ridge, Camp Nelson quadrangle, California. 
TABLE 6.-Rock name and description of sample locality-Con. KA No.
(unless otherwise
indicated) 1566 _ Unnamed

1568 do

1569 do quadrangle, California.

In most westerly $1 / 4$ mile of granite outcrops west-northwest of Woody on WoodyDelano- Road, 6.4 miles west of Woody, Woody quadrangle, California.

1570 do.

1.2 miles northeast of Woody on WoodyGreenhorn Summit road, Woody quadrangle, California.

$1571 \ldots \ldots$ do 1.4 miles west of Lynns Valley on WoodyGreenhorn Summit road, Woody quadrangle, California. $1572 \ldots . . .65$ miles east of Glennville on Woody-Greenhorn Summit road, Tobias Peak 30 minute quadrangle, California.

1573 do 3.50 miles east of west boundary of Sequoia National Forest, just west of Cedar Creek on highway, Tobias Peak quadrangle, California.

1574 - do_

1.25 miles east of Greenhorn Summit at 5,780 $\mathrm{ft}$ on highway, Tobias Peak 30 minute quadrangle, California.

1575 . . . . . . do........ 3t 3,750 ft on highway 5.6 miles east of Greenhorn Summit, Kernville 30 minute quadrangle, California.

1576 do. French Gulch, at Kern County Camp No. 3 on Kernville-Isabella road, Isabella quadrangle, California.

1577 do.

On California State Highway 178, 3.0 miles east of intersection with KernvilleIsabella road, Isabella quadrangle, California.
TABLE 6.-Rock name and description of sample locality-Con. KA No.

(unless otherwise
indicated)

1578 Unnamed 1.2 miles west of Weldon on California State Highway 178, Isabella quadrangle, California.

1579 1.2 miles east of Onyx on California State Highway 178, Onyx quadrangle, California.

1580 At 2,900 ft on California State Highway 178, on west end of ridge across creek from Bloomfield Ranch, Onyx quadrangle, California.

1581 At. 3,450 ft on California State Highway 178, approximately 0.55 miles west of intersection of Canebrake and Spanish Needle Creeks, Lamont Peak quadrangle, California.

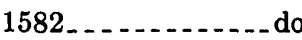
At 4,410 ft on California State Highway 178 , just west of intersection of Canebrake and Three Pines Canyon Creeks, Onyx quadrangle, California.

1583_. . . . Cathedral Peak type. Alabama Hills, on road to Whitney Portal, Lone Pine quadrangle. California.

1584_...... Whitney pluton..... At Whitney Portal, $8,480 \mathrm{ft}$, Lone Pine quadrangle, California.

1585 do At $9,500 \mathrm{ft}$ on Olancha Peak, Olancha quadrangle, California.

$1586 \ldots \ldots$. . . . . . . . . . . . . At $680 \mathrm{ft}$ on Golden Trout Creek, Kern Peak quadrangle, California.

1587 do At 9,280 ft on Wallace Creek Trail, Mount Whitney quadrangle, California.

1588

At $11,530 \mathrm{ft}$ on west side of Trailcrest along trail, Mount Whitney quadrangle. California.

1589 do

At 11,500 ft along Tyndall Creek, Mount Whitney quadrangle, California.

1590 do Mount Whitney qua rangle, California. 
TABLE 6.-Rock name and description of sample locality-Con.

\section{KA No. \\ (unless othernodse
indicated) Rock name}

1591

Unnamed

1592

do.

1593...... Cathedral Peak Granite.

1594 do.

1595 do. Locality

At $11,600 \mathrm{ft}$ on east side of Trailcrest along trail Mount Whitney quadrangle, California.

At 7,680 ft on Whitney Portal Road, Lone Pine quadrangle California.

$40 \mathrm{ft}$ below summit of Cathedral Peak, Tuolumne Meadows quadrangle, California.

At $8,700 \mathrm{ft}$ on east flank of Lembert Dome, Tuolumne Meadows quadrangle, California.

At $11,000 \mathrm{ft}$ on high point of ridge west of Little Slide C Canyon, Matterhorn Peak quadrangle, California.

1596 do. . . . . . . . At 9,200 ft west-northwest from KA 1595 on small tributary stream entering Robinson Creek from southeast, Matterhorn Peak quadrangle, California.

1597 do At 7,950 ft on Twin LakeBarney Lake trail, Matterhorn Peak quadrangle, California.

1598 do.

At 7,300 ft on Barney Lake trail, Matterhorn Peak quadrangle, California.

1599 do. At 9,000 ft on Kirkwood Creek, Tower Peak quadrangle California.

1600 Quartz monzonite of Lagille Peake

At $11,500 \mathrm{ft}$ on west side of Hermit Ridge, McGee Lakes basin, Mount Goddard quadrangle, California. (Cathedral Peak type).

1601 Lamarck Granodiorite.

1602 Unnamed do.

$$
\text { California. }
$$

1603

At 3,050 ft on Mineral King road, Mineral King quadrangle, California.

1604 At 3,900 ft on Mineral King road, Mineral King quadrangle, California.
TABLE 6.-Rock name and description of sample locality-Con. KA No. unless otherwoise
indicated) 1605 Rock name Locality At 4,050 $\mathrm{ft}$ on Mineral King road, Mineral King quadrangle, California.

1606 do

At $4,800 \mathrm{ft}$ on Mineral King road, Mineral King quadrangle, California.

1607 -do At 7,000 ft on Mineral King road, 1 mile east of Silver City, Mineral King quadrangle, California.

1608 .do. At top of Sawtooth Peak, $12,340 \mathrm{ft}$, Kaweah quadrangle, California.

1609 do

At 10,800 ft, head of Lost Canyon, east of Columbine Lake (virtually same locality as KA 1608), Kaweah quadrangle, California.

1610 -do At $11,600 \mathrm{ft}$ in Sawtooth Pass, Kaweah quadrangle, California.

1621 8.2 miles west of Tehachapi Railroad Station on California State Highway 58 (U.S. Highway 466) at $2,700 \mathrm{ft}$, Tehachapi quadrangle, California.

1624 1.0 mile east of $\mathrm{Mi}$-wuk Village on California State Highway 108, Long Barn quadrangle, California.

1626 do . . . . . . . . At east end of business district of Three Rivers on California State Highway 198.

1627 do

At southeast end of Bass Lake from borrow pit for dam, Bass Lake quadrangle, California.

1628 do

0.8 mile west of west end of Oakhurst bridge on California State Highway 41, Bass Lake quadrangle, California.

1629 1.05 miles west of Horse Creek Road turnoff, 4.75 miles east of Woodlake turnoff on California State Highway 198. 
TABLE 6.-Rock name and description of sample locality-Con. KA No.
(unless otherwise
indicated) 1630 . . . . . . Unnamed.

1633

1634 do

0.65 mile west of Soulsbyville turnoff, 2.6 miles east of Standard turnoff, on California State Highway 108 , Sonora quadrangle, California.

1635. do. do

0.1 mile west of Dorrington on California State Highway 4 at $4,800 \mathrm{ft}$, Blue Mount quadrangle, California.

1636 0.5 mile west of Poison Spring at $6,560 \mathrm{ft}$ on California State Highway 4, Big Meadow quadrangle, California.

1663. Granodiorite of The Gateway (Calkins, 1930).

1664 Unnamed

\section{At} of Yosemite National Park on California State Highway 140. 0.8 mile east of Avery at $3,500 \mathrm{ft}$ on California State Highway 4, Columbia quadrangle, California.

1665 do 1.9 miles northwest of Wawona on California State Highway 41 at approximately $4,200 \mathrm{ft}$, Yosemite National Park.

1666 5.2 miles east of Road 208, 7.3 miles east of California State Highway 145, on California State Highway 41, at $1,150 \mathrm{ft}$.
TABLE 6.-Rock name and description of sample locality-Con.

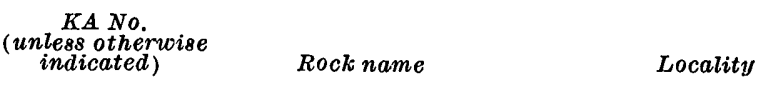
Campground on U.S. Highway 50, Fallen Leaf Lake quadrangle, California.

1679 east of hairpin turn, at $90^{\circ}$ turn, west of Camp Sacramento on U.S. Highway 50, Fallen Leaf Lake quadrangle, California.

1683 0.8 mile west of Silver Fork at $3,880 \mathrm{ft}$ on U.S. Highway 50, Robbs Peak quadrangle, California.

1697 At $6,020 \mathrm{ft}$ on west side of U.S. Highway 395 along West Walker River at north end of Shingle Mill Flat.

1698 do 4.5 miles west of Silver Fork at $3,500 \mathrm{ft}$ on U.S. Highway 50, Robbs Peak quadrangle, California.

1699 1.6 miles west of Whitehall on U.S. Highway 50, Robbs Peak quadrangle, California.

1700 4.8 miles west of Whitehall, 0.5 mile east of Bridalveil picnic area, on U.S. Highway 50, Robbs Peak quadrangle, California.

1701 do

Where California State Highway 49 crosses Middle Fork Yuba River, Camptonville quadrangle, California.

1702 do 1.3 miles west of Chap man Creek Campground on California State Highway 49, Sierra City quadrangle, California.

DKA 1028_.. Granodiorite of Mono Dome (Kistler, 1966a).

California State Highway 120,1 mile north of Ellery Lake, Mono Craters quadrangle, California.

DKA 1029..... do California State Highway 120,1 mile north of Ellery Lake, Mono Craters quadrangle, California. 
TABLE 6.-Rock name and description of sample locality-Con.

$\begin{array}{cc}\begin{array}{c}\text { KA No. } \\ \text { (unless othervisc } \\ \text { indicated) }\end{array} & \text { Rock name } \\ \text { MKA 409....- } & \begin{array}{c}\text { Granodiorite of } \\ \text { Mono Dome } \\ \end{array} \\ & \text { (Kistler, 1966a). }\end{array}$

MKA 41..... Quartz monzonite of Ellery Lake (Kistler 1966a).

DKA 1031_.. Granodiorite of Mono Dome (Kistler, 1966a).

DKA 1032 - do

DKA 1030 do.

Elevation 11,100 ft, 1.2 miles southeast of Lee Vining Peak, Mono Craters quadrangle, California.

MKA 410 do......... Elevation 11,100 ft, 1.2 miles southeast of Lee Vining Peak, Mono Craters quadrangle, California.

BKA 558 do.

BM 8615, California State Highway 120 , Mono Craters quadrangle, California,

MKA 42... Wheeler Crest Quartz Monzonite (Kistler, 1966a).

Hill 9962, 2 miles south of Mono Dome, Mono Craters quadrangle, California.

BKA 488.-.- Quartz monzonite of Aeolian Buttes (Kistler, 1966a).

$61-192$ do.

Hill 7451, Aeolian Buttes, Mono Craters quadrangle, California. Hill 7451, Aeolian Buttes, Mono Craters quadrangle, California.

BKA 487.-. - Wheeler Crest Quartz Monzonite (Kistler, 1966a).

MKA 458. Roadcut, just northeast, of town of June Lake, Mono Craters quadrangle, California.

Roadcut, just northeast of town of June Lake Mono Craters quadrangle, California.

BKA 556.... Granodiorite of Kuna Crest

Elevation $11,600 \mathrm{ft}$, 0.25 mile north of (Kistler, 1966a). Donohue Peak, Mono Craters quadrangle, California.

BKA 557... Granodiorite of Rush Creek (Kistler, 1966a).

$61-041$ Unnamed.

Lake, Mono Craters
TABLE 6.-Rock name and description of sample locality-Con.

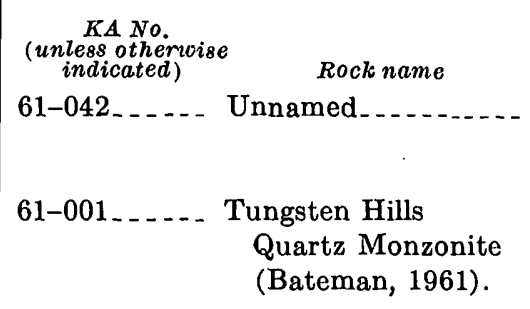

61-020 . . . . . do quadrangle, California. Elevation 10,000 ft, North Fork, Piute Creek, Mount Abbot quadrangle, California.

MKA 51.... Unnamed......... Burgess mine, New York Butte quadrangle, California.

61-047.....- Santa Rita Flat Independence quadpluton of the Tinemaha Granodiorite (Ross, 1965).

61-043....- Quartz monzonite of Independence quadPiute Monument rangle, California. (Ross, 1965).

61-045..... Tinemaha Granodiorite (Ross, 1965).

61-044_... . . Pat Keys pluton (Ross, 1965).

61-019..... Unnamed

Independence quadrangle, California.

Waucoba Mountain quadrangle, California.

Comanche Gulch, Blind Spring Hill, Benton quadrangle, California.

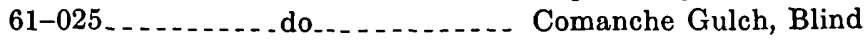
Spring Hill, Benton quadrangle, California.

$61-166$ Comanche Gulch, Blind Spring Hill, Benton quadrangle, California.

61-003 3 miles south of Cowtrack Mountain, Cowtrack Mountain quadrangle, California.

61-017 . . . . . do......... 2 miles southwest of Cowtrack Mountain, Cowtrack Mountain quadrangle, California.

$61-008$ California State Highway $120,1.5$ miles south of River Spring Lakes, Glass Mountain quadrangle, California.

61-026......... do .......... California State Highway $120,1.5$ miles south of River Spring Lakes, Glass Mountain quadrangle, California.

61-190 . . . . . do . . . . . 2 miles west of Schurz, Nev., north end of Wassuk Range.

61-191 .......... do .......... Valley between Gillis and Gabbs Valley Ranges, Nev., 1 mile east of Ryan Canyon Road. quadrangle, California.
Knowles, Ráymond
Knowy 1 mile south of quadrangle, California. Quarry, 1 mile south of Knowles, Raymond quadrangle, California. 
TABLE 6.-Rock name and description of sample locality-Con. KA No.
(unless otherwoise
indicated)

61-007 Unnamed

At crest of Gillis Range
Nev., on Ryan Can-
yon Road.

At crest of Gillis Range
Nev., on Ryan Can-
yon Road.

At crest of Gillis R
Nev., on Ryan
yon Road. State Highway 23 in Gabbs Valley Range.

71-002 . . . In Garfield Hills, due south of Luning, Nev.

71-006 . . . . . . . . . . . . . . . . Road, due south of Cory Peak, Wassuk Range, Nev.

61-194_... Mouth of Powell Canyon Wassuk Range, Nev.

71-022 . . . . . do........ On road from Hawthorne Nev., to Huntoon Valley, Nev., north side of Excelsior Mountains.

61-196 . . . . . do....... On road from Hawthorne, Nev., to Huntoon Valley, Nev., north side of Excelsior Mountains.

61-188 Nev., to Huntoon Valley, Nev., at north end of Huntoon Valley.

71-079._._. Granite of Rubidoux Mountain (Larsen, 1948).

71-073. do.

Mount Rubidoux, Riverside West, 7.5-minute quadrangle, California.

Mount Rubidoux, Riverside West, 7.5-minute quadrangle, California.

71-083.... - San Marcos Gabbro Twin Oaks Valley Road, (Larsen, 1948).

71-067. do. quarry in Gopher Canyon, San Marcos, 7.5-minute quadrangle, California.

Twin Oaks Valley Road, quarry in Gopher 7.5-minute quadrangle, California.

71-069_.... Green Valley Tonalite.

California State Highway 78, 1 mile east of San Pasqual Battlefield State Historical Monument, San Pasqual 7.5minute quadrangle, California.

61-119_..... Biotite hornblende gabbro (Compton, 1966). ornblendite in Arroyo Seco, 1/8 mile northnorthwest of confluence Canyon, San Marcos

TABLE 6.-Rock name and description of sample locality-Con. KA No.
(unless otherroise
indicated)

61-117_..... Biotite hornblende Rock name Locality gabbro (Compton, 1966).

orthwest end of main Junipero Serra Pluton, Junipero Serra quadrangle, California.

MKA 399.... Granodiorite....... . Bodega Head, Sonoma County, Calif.

591 _....... Unnamed _....... Mururata-Tasquesi, Bolivia.

71-075..... Bonsall Tonalite Val Verdi Tunnel, Cajalco Road, Steele Peak,

(Larsen, 1948). 7.5-minute quadrangle California.

71-061_. Road, Steele Peak, 7.5-minute quadrangle, California.

71-063..... Lakeview Mountain Nuevo Road, 2 miles Tonalite (Larsen, west of Nuevo, Perris 1948). 7.5-minute quadrangle California.

71-081_. . . - Woodson Mountain - U.S. Highway 395, near Granodiorite (Larsen, 1948). intersection with road to Rainbow, Temecula 7.5-minute quadrangle, California.

71-071_. intersection with road to Rainbow, Temecula 7.5-minute quadrangle, California.

71-077_.... Sphene-rich tonalite. Near Tool Box Spring, Thomas Mountain, Idyllwild quadrangle, California.

71-065 . . . . do do Tool Box Spring, Thomas Mountain, Idyllwild quadrangle, California.

620....... Muscovite from Chojilla, Unduavi, cassiterite vein. Bolivia.

634. . . .... Granite. . . . . . . Carhuamayo, Peru.

1466. . . . . . Gneiss . . . . . . . . Cerro Machani, Peru.

1158....... Small stock, intrudes Ocona, Peru. Mitu Group of Middle to Late Permian age.

1159....... Syenite, cuts Mitu Oscuyo-Ayapata, Peru. Group.

1145....... Cumbre de Achasiri Cumbre de Achasirigranite $(60 \mathrm{~km} \times \quad$ Coasa, Peru. $15 \mathrm{~km}$ ), intrudes Pennsylvanian and older rocks.

1155 Diorite

Cañon de Marcapata, Peru.

1454_..... Granite, intrudes Devonian sedi-

H. Potosi batholith, with Santa Lucia Creek, Junipero Serra quadrangle, California. mentary rocks.

1374 . . . . Gneiss . . . . . . . Jones, Guatemala. 615......... Sorata batholith.... Candelaria, Cooco, Bolivia. 